\title{
Classification, Natural History, and Evolution of Tarsosteninae (Coleoptera: Cleridae)_Part I: Generic Composition of the Subfamily and Key and Phylogeny of Genera
}

\author{
Weston Opitz \\ Department of Biology, Kansas Wesleyan University, 100 East Claflin Avenue, Salina, KS 67401-6196, USA \\ Correspondence should be addressed to Weston Opitz, opitz@kwu.edu
}

Received 4 July 2011; Accepted 1 September 2011

Academic Editor: Ai-Ping Liang

Copyright (C) 2012 Weston Opitz. This is an open access article distributed under the Creative Commons Attribution License, which permits unrestricted use, distribution, and reproduction in any medium, provided the original work is properly cited.

\begin{abstract}
Four new genera and one new species of the subfamily Tarsosteninae (Coleoptera: Cleridae) are described. The new genera are: Agapetilus Opitz, gen. nov., Fallopylus Opitz, gen., nov, Globoclava Opitz, gen. nov., and Pseudopylus Opitz, gen. nov. The new species involves Agapetilus vietus Opitz. sp. nov. Liostylus Fairmaire is synonymized with Rhophaloclerus Fairmaire. New combinations, Fallopylus pallipes (MacLeay, 1872), comb. nov., Globoclava quadrimaculata (Chevrolat, 1876), comb. nov., Parapylus sedlaceki (Kolibáč, 2003), comb. nov., Pseudopylus okei (Elston, 1929), comb. nov., and Rhophaloclerus pictus (Fairmaire, 1902), comb. nov., are established. A key and phylogeny of the genera of Tarsosteninae is provided.
\end{abstract}

\section{Introduction}

According to Opitz [1] there are six subfamilies in the Cleridae whose specimens have the fourth tarsomere reduced. The elucidation of the generic composition of these subfamilies, and their intrasubfamilial relationships, is the focus of the research program of the author. This contribution involves Tarsosteninae. It is the fourth of a series of works that makes known the generic composition of the six subfamilies referenced above. The first three contributions involve Epiphloeinae Kuwert [2], Neorthopleurinae Barr [3], and Korynetinae Laporte [4]. The revisions of the remaining two subfamilies, the Peloniinae Opitz and Enopliinae Gistel, are in various stages of preparation.

\section{Taxonomic History}

The majority of the generic taxa herein classified in Tarsosteninae were originally grouped under other subfamilies:
Rhophaloclerus Fairmaire in Tillinae [5]; Abeliella Peracchi, Curacavi Solervicens, Apteropilo Lea, and Neopylus Solervicens in Enopliinae [5]; Apopylus Kolibáč, Blackburniella Chapin, Parapylus Blackburn, Pylus Newman, Tarsostenodes Blackburn, Thriocera Gorham; Riotenerus Pic in Peloniinae [1]; Tarsostenosis Heller and Thriocerodes Wolcott \& Dybas in Korynetinae [6]. It is likely that the monotypic Pallenothriocera Pic, presently classified in Korynetinae, also belongs in Tarsosteninae. However, the specimen representing this nominal genus has not been found.

\section{Material and Methods}

For the most part the entire inventory of species of each genus was examined and several nonconspecific specimens of genera were disarticulated to examine the more cryptic structures of the integument. Methods and concepts involving dissection, measurements, terminology, specific and generic 
delimitations, and preparation of illustrations were similar to those implemented in [1].

\section{Systematics}

4.1. Phylogenetics of Genera. The concepts of Hennig's phylogenetics were implemented in this treatise [7]. This involved the preparation of a suite of character states and a character matrix (Table 1), which was analyzed via NONA [8] in combination with Winclada version 1.00.08 [9]. The analysis generated 58 trees, with 46 steps, index of consistency of 58, and an index of retention of 74 . The 58 trees were examined and the one selected (Figure 24) most closely approximates a tree prepared manually. Heuristic analysis (maximum trees (hold) $=100$, number of replications 9 (mult) $=100$, and multiple TBR (mult max)) was used.

4.2. Character States. Twenty-seven character states were used to analyze the phylogenetic relationships among the genera of Tarsosteninae. Outgroups included taxa of Korynetinae [4]. Character states valued " 0 " are considered plesiotypic, whereas those assigned a value of " 1 " are interpreted as apotypic (Table 1). The methods by which the phylogenetic state of a characteristic is determined are well documented $[10,11]$.

Character 0

Unguis denticle: (0) absent; (1) present

Character 1

Pronotal tubercle: (0) absent; (1) present

Character 2

Pronotal tubercle: (0) slightly developed; (1) highly developed

Character 3

Asetiferous punctations: (0) present; (0) absent

Character 4

Ninth row of elytral asetiferous punctations: (0) not reduced; (1) reduced

Character 5

Elytral $2^{\circ}$ : (0) present; (1) absent

Character 6

Terminal maxillary palpomere: (0) digitiform;

(1) somewhat securiform

Character 7

Terminal maxillary palpomere: (0) subsecuriform; (1) securiform

Character 8

Tibial spur formula: (0) 2-2-2; (1) 0-1-1

Character 9

Tibial spur formula: (0) 2-2-2; (1) 1-2-1

Character 10

Tibial spur formula: (0) 2-2-2; (1) 0-0-0

\section{Character 11}

Tarsal pulvillar formula: (0) 3-3-3; (1) third pulvillus reduced

Character 12

Ommatidia: (0) large; (1) small

Character 13

Capitulum: (0) compact; (1) lax

Character 14

Pronotal sides: (0) smooth; (1) crenulated

Character 15

Eye: (0) large; (1) small

Character 16

Ocular plate: (0) small; (1) large

Character 17

Elytral asetiferous punctations nodes: (0) absent; (1) present

\section{Character 18}

Pronotal indentations: (0) absent; (1) present

Character 19

Pronotal collar: (0) not extended; (1) extended

Character 20

Elytral asetiferous punctations: (0) to elytral apex; (1) to elytral half

\section{Character 21}

Pronotal disc: (0) without glabrous elevations;

(1) with glabrous elevations

Character 22

Pronotal disc: (0) without glabrous spots;

(1) with glabrous spots

Character 23

Pronotal disc: (0) without narrow glabrous streaks; (1) with narrow glabrous streaks

Character 24

Gular process: (0) not confluent; (1) confluent

Character 25

Pronotal commissure: (0) absent; (1) present

Character 26

Capitulum: (0) not much shorter than rest of antennal length; (1) much shorter than rest of antenna. 


\subsection{Key to Genera of Tarsosteninae.}

1 Unguis with denticle (Figure 15(j))

$1^{\prime}$. Unguis without denticle (Figure 15(i))

2(1). Last antennomere globose, about three times larger than penultimate antennomere (South Africa)

$2^{\prime}$. Last antennomere only slightly larger than penultimate antennomere

$3\left(2^{\prime}\right)$. Body form oblong narrow (Figure 22(b)), pronotum oblong (Tanzania)

$3^{\prime}$. Body form oblong broad (Figure 23(h)), pronotum transverse (Democratic Republic of the Congo, Kenya, Mozambique, South Africa, Tanzania)

$4\left(1^{\prime}\right)$. Pronotal sides without vestige of tubercle (Figure 14(b))

$4^{\prime}$. Pronotal sides with shallow (Figure $1(\mathrm{~d})$ ) or with well defined projecting tubercle (Figure 4(c))

5(4). Pronotum subquadrate (Madagascar)

$5^{\prime}$. Pronotum distinctly oblong

$6\left(5^{\prime}\right)$. Elytral disc with 8 rows of punctations; pronotal disc uniformly scabrous (Bolivia, Brazil, Uruguay)

6. Elytral disc with 10 rows of punctations; pronotal disc with glabrous streaks (Cosmopolitan)

$7\left(4^{\prime}\right)$. Pronotal sides with shallow tubercle (Figure $1(\mathrm{~d})$ )

Globoclava gen. nov

3

Agapetilus gen.nov

Thriocera Gorham

5

7

Rhophaloclerus Fairmaire

6

$7^{\prime}$. Pronotal sides with well defined projecting tubercle (Figure 4(c))

$8(7)$. Last maxillary palpomere distinctly securiform (Figure 12(a))

Abiliella Peracchi

$8^{\prime}$. Last maxillary palpomere subsecuriform (Figure 6(c))

9(8). Pronotal side margins serrulated (Chile)

$9^{\prime}$. Pronotal side margins not serrulated

Tarsostenus Spinola

$10\left(9^{\prime}\right)$. Metabasitarsal pulvillus well developed

8

$10^{\prime}$. Metabasitarsal pulvillus not well developed or absent

14

11(10). Pronotum distinctly oblong (Australia)

$11^{\prime}$. Pronotum quadrate (Australia)

$12\left(10^{\prime}\right)$. Elytral asetiferous punctations nodulated (Australia)

$12^{\prime}$. Elytral asetiferous punctations not nodulated (New Caledonia).

$13\left(8^{\prime}\right)$. Pronotum distinctly oblong (Argentina)

$13^{\prime}$. Pronotum subquadrate (Australia)

$14\left(7^{\prime}\right)$. Apical maxillary palpomere distinctly securiform

$14^{\prime}$. Apical maxillary palpomere subsecuriform

15(14). Rows of elytral asetiferous punctations not defined (Chile)

15. Rows of elytral asetiferous punctations clearly defined

16(15). Pronotum with glabrous tumescences (Australia)

16. Pronotum without glabrous tumescences (Australia)

$17\left(14^{\prime}\right)$. Elytral base with tumescence (Australia)

$17^{\prime}$. Elytral base without tumescence

$18\left(17^{\prime}\right)$. Tibial spur formula 2-2-1 (Australia)

$18^{\prime}$. Tibial spur formula 1-2-2 (Australia)

9

13

Curacavi Solervicens

10

11

12

Tarsostenodes Blackburn

Blackburniella Chapin

Apopylus Kolibáč

Tarsostenosis Heller

Riotenerus Pic

Thriocerodes Wolcott \& Dybas

15

17

Neopylus Solervicens

16

Apteropilo Lea

Pseudopylus gen.nov.

Parapylus Blackburn

18

Pylus Newman

Fallopylus gen. nov.

\subsection{Description of Tarsosteninae}

Type Genus. Tarsostenus Spinola [12].

Diagnosis. These beetles have a reduced 4 th tarsomere, do not have a pair of pronotal trichobothria, and have long capitate antennae in which the funicular antennomeres are filiform and the length of the capitulum is not as long as the combined length of the remainder of the antennomeres. The incomplete dorsolateral pronotal carina is confluent with the pronotal hem at the posterior angles of the pronotum.
Description. Shape: ranges from narrow rectangulate to short rectangulate. Size: length $2.2-14.0 \mathrm{~mm}$; width $0.6-6.0 \mathrm{~mm}$. Integumental color: Varies from uniformly reddish-brown to multicolored conditions where the integument is mostly dark brown and the elytral disc shows a paler fascia, in very few cases the integument may be shiny blue or shiny multicolored with red, yellow and brown. Head: transverse, strongly deflexed, usually narrower than pronotum, surface usually finely punctated; epistomal suture faintly indicated; internal epistomal ridge poorly developed; clypeus bipartite, comprised of pigmented upper region and nonpigmented 
TABLE 1: Character matrix for 27 morphological characters of Tarsosteninae genera.

\begin{tabular}{|c|c|c|c|c|c|c|c|c|c|c|c|c|c|c|c|c|c|c|c|c|c|c|c|c|c|c|c|}
\hline \multirow{3}{*}{ Taxa } & \multicolumn{27}{|c|}{ Characters } \\
\hline & & & & & & & & & & & 1 & 1 & 1 & 1 & 1 & 1 & 1 & 1 & 1 & 1 & 2 & 2 & 2 & 2 & 2 & 2 & 2 \\
\hline & 0 & 1 & 2 & 3 & 4 & 5 & 6 & 7 & 8 & 9 & 0 & 1 & 2 & 3 & 4 & 5 & 6 & 7 & 8 & 9 & 0 & 1 & 2 & 3 & 4 & 5 & 6 \\
\hline Outgroup & 0 & 0 & 0 & 0 & 0 & 0 & 0 & 0 & 0 & 0 & 0 & 0 & 0 & 0 & 0 & 0 & 0 & 0 & 0 & 0 & 0 & 0 & 0 & 0 & 1 & 1 & 0 \\
\hline Abeliella & 0 & 0 & 0 & 0 & 0 & 0 & 1 & 1 & 1 & 0 & 0 & 1 & 0 & 1 & 0 & 0 & 0 & 1 & 0 & 0 & 0 & 0 & 0 & 0 & 0 & 0 & 1 \\
\hline Agapetilus & 1 & 0 & 0 & 1 & 0 & 0 & 1 & 0 & 0 & 0 & 0 & 1 & 0 & 1 & 0 & 0 & 0 & 0 & 0 & 0 & 0 & 0 & 0 & 0 & 0 & 0 & 1 \\
\hline Apopylus & 0 & 1 & 0 & 0 & 1 & 1 & 1 & 0 & 0 & 1 & 0 & 0 & 0 & 0 & 0 & 0 & 1 & 1 & 0 & 0 & 0 & 0 & 0 & 0 & 0 & 0 & 1 \\
\hline Apteropilo & 0 & 1 & 1 & 0 & 0 & 0 & 1 & 1 & 0 & 0 & 0 & 0 & 0 & 0 & 1 & 1 & 1 & 1 & 1 & 0 & 0 & 1 & 1 & 0 & 0 & 0 & 1 \\
\hline Blackburniella & 0 & 1 & 0 & 0 & 0 & 0 & 1 & 1 & 0 & 1 & 0 & 0 & 0 & 0 & 0 & 0 & 0 & 0 & 1 & 0 & 0 & 0 & 0 & 0 & 0 & 0 & 1 \\
\hline Curacavy & 0 & 1 & 0 & 0 & 0 & 1 & 1 & 0 & 0 & 0 & 0 & 0 & 0 & 0 & 1 & 0 & 0 & 1 & 0 & 0 & 0 & 0 & 0 & 0 & 0 & 0 & 1 \\
\hline Fallopylus & 0 & 1 & 1 & 0 & 1 & 1 & 1 & 0 & 0 & 0 & 0 & 0 & 0 & 0 & 0 & 0 & 1 & 1 & 1 & 0 & 0 & 0 & 0 & 0 & 0 & 0 & 1 \\
\hline Globoclava & 1 & 0 & 0 & 0 & 0 & 0 & 1 & 0 & 1 & 0 & 0 & 1 & 0 & 0 & 0 & 0 & 0 & 0 & 0 & 0 & 0 & 0 & 0 & 0 & 0 & 0 & 1 \\
\hline Neopylus & 0 & 1 & 1 & 0 & 0 & 0 & 1 & 1 & 0 & 0 & 0 & 0 & 0 & 0 & 0 & 0 & 1 & 1 & 1 & 0 & 0 & 0 & 0 & 0 & 0 & 0 & 1 \\
\hline Parapylus & 0 & 1 & 1 & 0 & 0 & 0 & 1 & 0 & 0 & 0 & 0 & 0 & 0 & 0 & 0 & 0 & 1 & 1 & 1 & 0 & 0 & 0 & 0 & 0 & 0 & 0 & 1 \\
\hline Pseudopylus & 0 & 1 & 1 & 0 & 1 & 1 & 1 & 0 & 0 & 0 & 1 & 0 & 0 & 0 & 0 & 0 & 1 & 1 & 1 & 0 & 0 & 0 & 0 & 0 & 0 & 0 & 1 \\
\hline Pylus & 0 & 1 & 1 & 0 & 1 & 1 & 1 & 0 & 0 & 0 & 0 & 0 & 0 & 0 & 0 & 0 & 1 & 1 & 1 & 0 & 0 & 0 & 0 & 0 & 0 & 0 & 1 \\
\hline Rhophaloclerus & 0 & 0 & 0 & 0 & 0 & 0 & 1 & 1 & 0 & 0 & 0 & 1 & 1 & 1 & 0 & 0 & 0 & 0 & 0 & 0 & 0 & 0 & 0 & 0 & 0 & 0 & 1 \\
\hline Riotenerus & 0 & 1 & 0 & 0 & 0 & 0 & 1 & 0 & 1 & 0 & 0 & 1 & 0 & 1 & 0 & 0 & 0 & 0 & 0 & 0 & 0 & 0 & 0 & 0 & 0 & 0 & 1 \\
\hline Tarsostenodes & 0 & 1 & 0 & 0 & 0 & 0 & 1 & 1 & 0 & 1 & 0 & 0 & 0 & 1 & 0 & 0 & 0 & 0 & 0 & 1 & 0 & 0 & 0 & 0 & 0 & 0 & 1 \\
\hline Tarsostenosis & 0 & 1 & 0 & 0 & 0 & 0 & 1 & 1 & 0 & 1 & 0 & 1 & 0 & 1 & 0 & 0 & 0 & 0 & 0 & 0 & 1 & 1 & 0 & 1 & 0 & 0 & 1 \\
\hline Tarsostenus & 0 & 0 & 0 & 0 & 0 & 0 & 1 & 1 & 0 & 1 & 0 & 0 & 0 & 1 & 0 & 0 & 0 & 0 & 0 & 0 & 0 & 1 & 0 & 1 & 0 & 0 & 1 \\
\hline Thriocera & 1 & 0 & 0 & 0 & 0 & 0 & 1 & 0 & 0 & 0 & 0 & 0 & 1 & 1 & 0 & 0 & 0 & 0 & 0 & 0 & 0 & 0 & 0 & 0 & 0 & 0 & 1 \\
\hline Thriocerodes & 0 & 0 & 0 & 0 & 0 & 0 & 1 & 0 & 0 & 1 & 0 & 1 & 0 & 1 & 0 & 0 & 0 & 0 & 0 & 0 & 0 & 0 & 0 & 0 & 0 & 0 & 1 \\
\hline
\end{tabular}

lower region; antenna comprised of 11 antennomeres, capitate, capitulum shorter than length of combined other antennomeres, noncapitular antennomeres filiform; frontal preantennal angle not acute; eyes coarsely to finely faceted, slightly notched anteriorly; labrum shallowly incised, transverse tormal processes fused contiguous; epipharynx not complex; last palpomere of maxillary and labial palpus boldly or slightly securiform; mandible with well-developed dens, basal notch not large; gula large, gular processes widely separated, gular sutures strongly converging. Thorax: pronotum usually transverse-quadrate, or elongate, lateral tubercle absent or strongly developed, anterior transverse depression present or not, dorsolateral carina incomplete or complete, always posteriorly confluent with pronotal hem, pronotal commissure absent; pronotal projections vary in lengths, prointercoxal process linear or expanded distally; pronototergosternal suture complete; procoxal cavity open, procryptosternum incomplete; metendosternite with furcal lamina; elytral form usually elongate rectangulate or short rectangulate, anterior margin with carina, disc with asetiferous punctations, $1^{\circ}$ and $2^{\circ}$ setae usually present, epipleural fold laterally positioned, gradually narrowing to elytral apical four-fifths, elytral punctations, plain, or bimodal or tetranodal; metathoracic wings present or not; legs, tarsal formula 5-5-5, cursorial, tibial spur formula 2-2-2, 2-2-1, $1-2-2,1-2-1,0-2-2$, or $0-0-0$, tarsal pulvillar formula 3-33 or $3-3-2$; unguis with (Figure $15(j))$ or without denticle (Figures 2(f) and 15(i)); wedge cell of metathoracic wing present or not, when present closed or open. Abdomen: comprised of 6 visible sternites, 6th visible sternite usually beneath 5th, robust and compact; pygidium quadrate or scutiform; aedeagus sometimes inverted, well sclerotized, tegmen tubular very sclerotized or lightly sclerotized, bilobed distally, tegminal lobes usually fimbriate, phallobasic rod variously developed, phallobasic apodeme well developed, phallic plates variously developed; spicular fork well developed, intraspicular plate linear, spicular apodeme variously fused; ovipositor not longer than abdomen, with multilobed dorsal and ventral lamina; oblique and ventral bacculi well developed. Alimentary canal (Figure 18(m)): stomodaeum short, proventricular valve comprised of 4 primary lobes (Figure 18(j)); ventriculus well developed, ventricular crypts poorly developed; 4 cryptonephridial Malpighian tubules; proctodaeum short in males and long in females. Mesodermal male reproductive organs: typically with two pairs of accessory glands, rarely with one pair of glands; testes comprised of multiple follicles. Mesodermal female reproductive organs: spermathecal capsule from faintly to highly sclerotized, spermathecal gland attached to apex or subapex of spermathecal capsule; saccular bursal copulatrix well developed bursal sclerite present or not; ovaries comprised of multiple follicles.

\subsection{Descriptions of Genera of Tarsosteninae}

4.5.1. Abiliella Peracchi (Figures 1, 2, and 22(a)). Abiliella Peracchi [13]. Type species: Abiliella fasciata Peracchi [13]. By monotypy. 

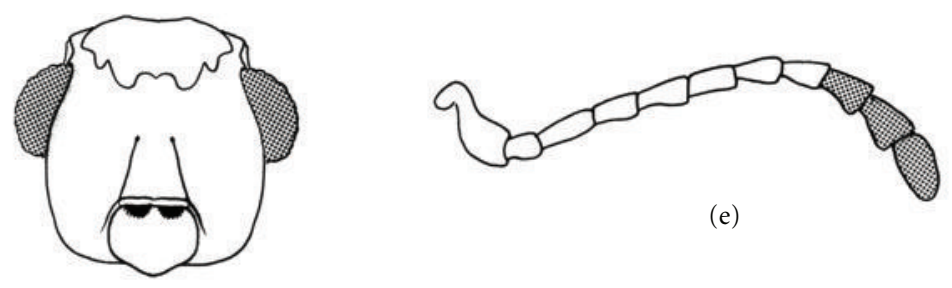

(e)

(a)
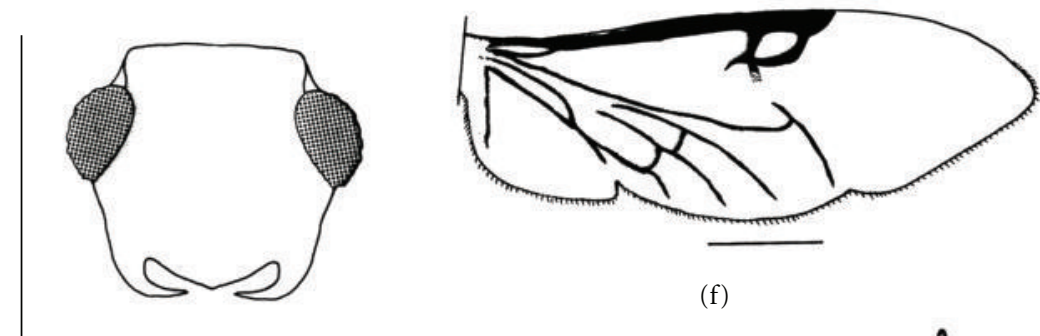

(b)

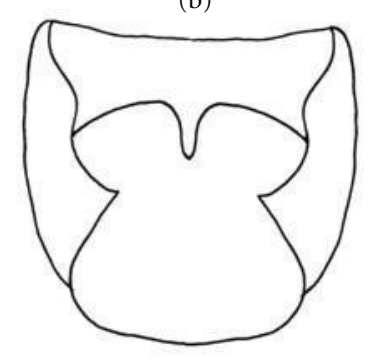

(f)

(c)

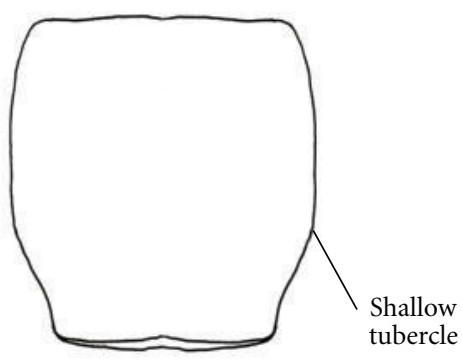

(d)

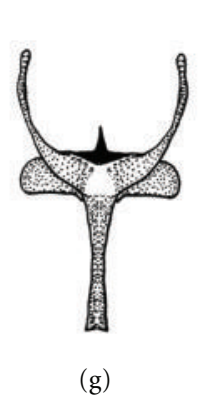

(g)

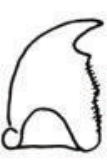

(h)

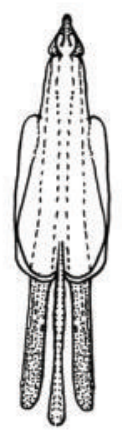

(i)

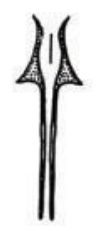

(j)

Figure 1: Various organs of Abiliella fasciata. (a, b) Head ((a) ventral, (b) dorsal). (c, d) Pronotum ((c) ventral, (d) dorsal). (e) Antenna. (f) Metathoracic wing. (g) Metendosternite. (h) Mandible. (i) Aedeagus. (j) Spiculum.

Synapotypic Characteristics. Pronotum elongate, elytral punctations binodal, epipleural margin serrulated, unguis without denticle, phallic plates very broad, and phallobasic lobes not fimbriate.

Diagnosis. Specimens of Abiliella are distinguishable from the superficially similar specimens of Tarsostenus by having only eight rows of elytral punctations; the elytral disc of Tarsostenus specimens have 10.

Description. Size: length $4.0-9.0 \mathrm{~mm}$; width $1.2-2.8 \mathrm{~mm}$. Form (Figure 22(a)): oblong rectangulate, about 3 times longer than broad. Vestiture: disc of cranium and pronotum vested with white setae, elytral disc vested with $1^{\circ}$ setae and shorter profusely distributed $2^{\circ}$ setae. Head (Figures 1(a), $1(\mathrm{~b})$, and 2(a)): cranium quadrate, frons wider than or narrower than width of eye, indented with large setiferous punctations that give cranium rugose appearance; gula (Figure 1(a)), large, trapezoidal, sutures oblique, gular processes widely separated, processes in form of two setiferous tubercles; labrum short, medial incision shallow, transverse tormal processes curvate, not confluent, epipharyngeal plate very small; mandible (Figure $1(\mathrm{~h})$ ), body short, anterior, medial dens well developed, posterior dens not well developed, penicillus well developed; maxilla (Figure 2(b)), laterolacinia present, terminal palpomere securiform; labium (Figure 2(b)), ligula not deeply incised, terminal palpomere 


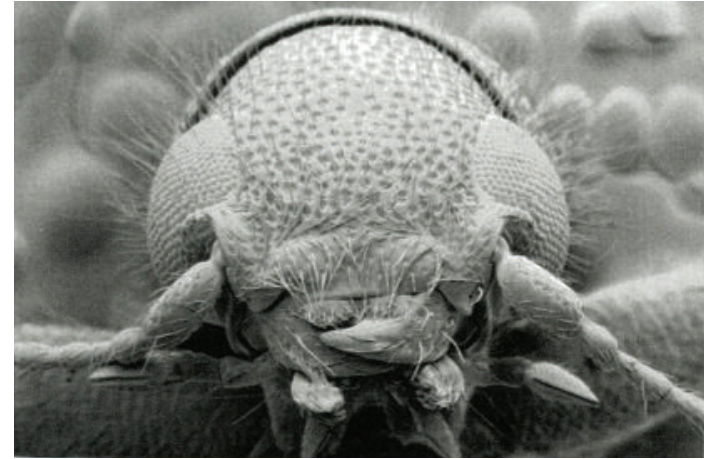

(a)

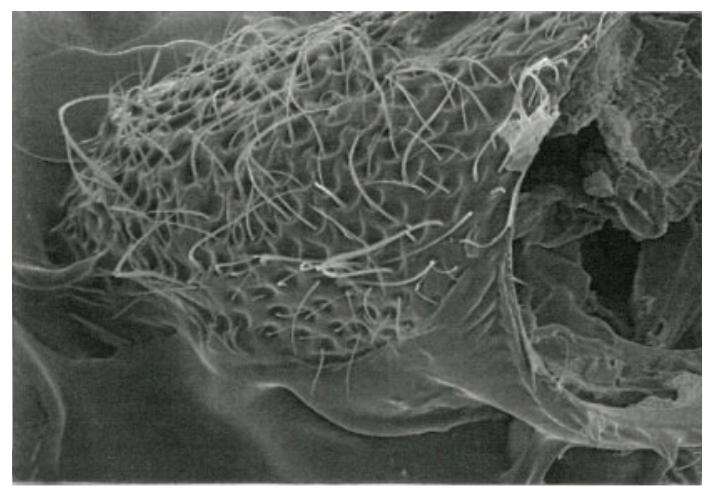

(c)

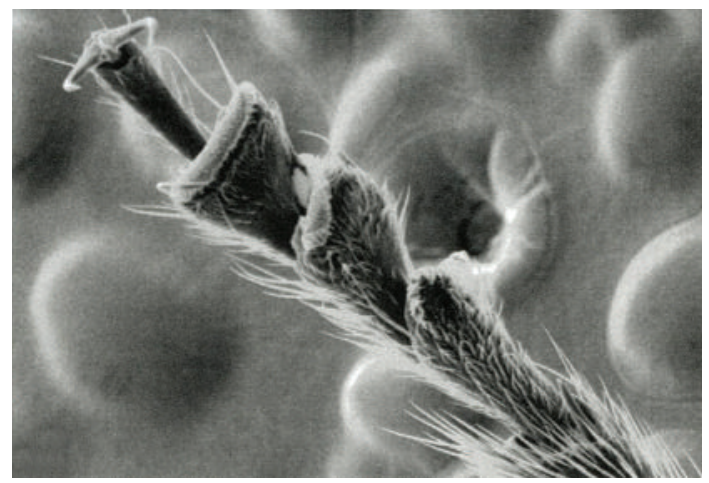

(e)

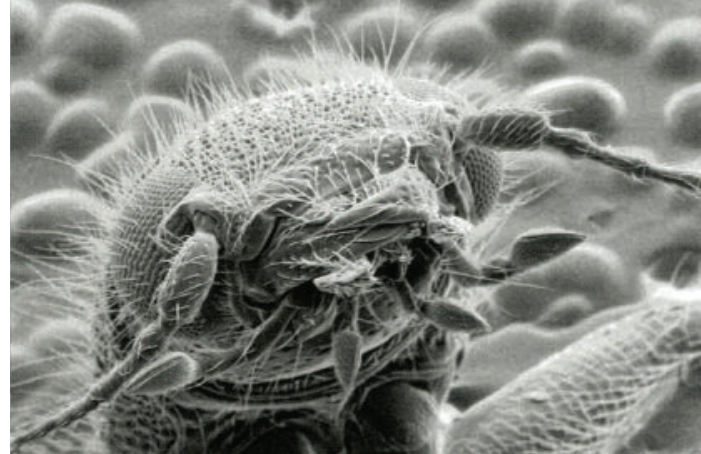

(b)

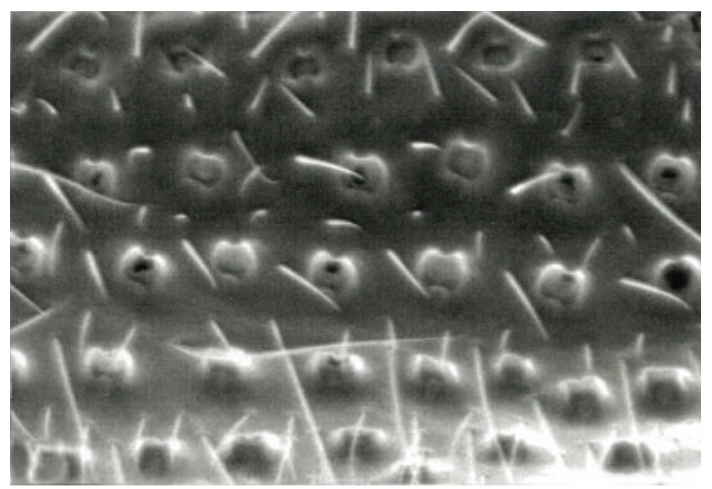

(d)

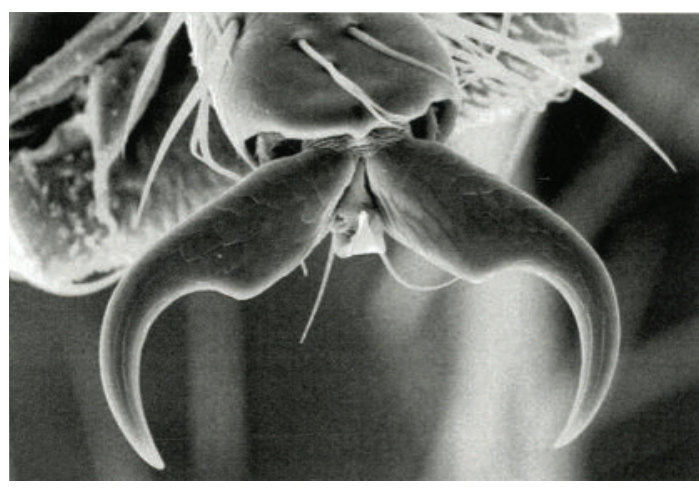

(f)

Figure 2: Various organs of Abiliella fasciata. (a) Head. (b) Mouthparts. (c) Pronotum (posterolateral angle). (d) Elytral surface (shows binodal asetiferous punctations). (e) Metatarsus. (f) Metatarsal unguis (shows absence of denticle).

securiform; eyes small or large, coarsely faceted, ocular notch large; antenna (Figure 1(e)), capitate, capitulum lax and narrow, scape about as long as combined length of pedicel and antennomere 3, funicular antennomeres filiform, capitular antennomeres narrow, antennomeres 9 and 10 subrectangular, antennomere 11 ovoid. Thorax: pronotum (Figures 1(c), 1(d), and 2(c)), elongate, convex, side margins slightly sinuous, sculptured with large round setiferous punctations, dorsolateral ridge extends from posterior angle to anterior angle (Figure 2(b)), surface smooth and not fractured by coarse punctations, prebasal fissure well developed, prointercoxal process not expanded distally; pronotal projections short; elytron sculptured with large spheroid asetiferous punctations, latter seriate and binodal (Figure 2(d)), $1^{\circ}$ setae always adjacent to asetiferous punctations, $2^{\circ}$ setae present, arranged serially, epipleural fold laterally positioned, extended to elytral apex, margin minutely serrulated, anterior margin carinate; metathoracic wing (Figure 1(f)), wedge cell open; metendosternite (Figure $1(\mathrm{~g})$ ), with furcal lamina, furcal anterior plate diminutive, acuminate; legs, tibial spur formula $0-1-1$, tarsal pulvillar formula 3-3-3 (Figure 2(e)), unguis without denticle. Abdomen: aedeagus (Figure 1(i)), shorter than length of abdomen, phallobase lobate distally, lobes not fimbriate; phallic lateral plates very broad, spicular plates triangular, acuminate, rarely, spicular apodemes not fused (Figure $1(\mathrm{j})$ ), intraspicular plate rod shaped; ovipositor, ventral and dorsal laminae unilobed, laminal rod present; distal margin of pygidium not incised, 
distal margin of male 6th sternite slightly incised. Alimentary canal: no information available. Male mesodermal internal reproductive organs: not studied. Female mesodermal internal reproductive organs: not studied.

Distribution. The members of this genus have been found only in Brazil and Bolivia.

Species Examined. Abiliella fasciata Peracchi and one new undescribed species.

4.5.2. Agapetilus gen. nov. (Figure 22(b)). Type species: Agapetilus vietus Opitz, sp. nov. Herein designated.

Synapotypic Characteristics. Pronotal wrinkles.

Diagnosis. The pronotal disc is profusely sculptured with wrinkles.

Description. Size: length $5.2 \mathrm{~mm}$; width $1.2 \mathrm{~mm}$. Form (Figure 22(b)): oblong, narrow rectangulate, about 5 times longer than broad. Vestiture: disc of cranium and pronotum densely vested with pale setae, elytral disc vested with $1^{\circ}$ setae, $2^{\circ}$ setae absent. Head: cranium quadrate, frons much wider than width of eye, indented with large setiferous punctations; gula large, trapezoidal, sutures oblique, gular processes widely separated, processes in form of two setiferous tubercles; labrum short, deeply incised, tormal processes not examined, epipharyngeal plate not examined; mandible, body short, anterior and medial dens well developed, posterior dens not well developed, penicillus not verified; maxilla well developed, laterolacinia not verified, terminal palpomere subsecuriform; labium, ligula deeply incised, terminal palpomere securiform; eyes small, coarsely faceted, ocular notch large; antenna, capitate, capitulum compact, scape about as long as combined length of pedicel and antennomere 3, funicular antennomeres filiform, capitular antennomeres slightly expanded, antennomeres 9 and 10 subtriangular, antennomere 11 ovoid. Thorax: pronotum oblong, disc sculptured with many wrinkles, prebasal fissure shallow, prointercoxal process not expanded distally, pronotal projections long; elytron sculptured with small setiferous punctations, basal tumescences present, asetiferous punctations absent, $1^{\circ}$ setae present, $2^{\circ}$ setae concentrated into medial fascia, interstitial spaces smooth, epipleural fold laterally positioned, very narrow to elytral apex, anterior margin not carinate; metathoracic wing not examined; metendosternite not examined; legs, tibial spur formula 0-2-2, tarsal pulvillar formula 3-3-3, unguis with denticle. Abdomen: aedeagus shorter than length of abdomen, phallobase not reduced, not lobate nor fimbriate; phallic lateral plates broad, phallobasic rod absent, phallic apex robust, spiculum not examined; ovipositor not examined. Alimentary canal: not studied. Male mesodermal internal reproductive organs: not studied. Female mesodermal internal reproductive organs: not studied.
Distribution. This monotypic genus is known only from Tanzania.

Species Examined. Agapetilus vietus Opitz, sp. nov.

Etymology. The generic name Agapetilus stems from the Latin petilus (=slender) and the intensive prefix aga- (=very). I refer to the slender body form of the type species.

\subsubsection{Agapetilus vietus Opitz, sp. nov.}

Type Material [Holotype o']. Tanzania, Tanga, Lushoto Dist., Mazumbai For. Res. $4^{\circ} 49^{\prime} \mathrm{S} 38^{\circ} 29^{\prime} \mathrm{E}, 1650-1730 \mathrm{~m}, 27$. XI.1995, Fog 29 II, Zmuc Denmark (Institute Royal des Sciences Naturelles de Belgique).

Description. Form: oblong slender. Size: length $5.2 \mathrm{~mm}$; width $1.2 \mathrm{~mm}$. Integumental color: Antenna, legs, and posterior half of elytral disc, and abdomen yellow-brown, forebody, pterothorax, and anterior half of elytral disc brown, with white fascia across middle of elytral disc. Male genitalia: Aedeagus very short, tegmen without lobes and posterior limit not fimbriate; phallic plates broad and apex pronounced.

Distribution. Known only from Tanzania.

Etymology. The specific epithet vietus (=wrinkled) is a Latin adjective. I refer to the extensive wrinkling on the pronotal disc.

4.5.4. Apopylus Kolibáč (Figures 4(h) and 22(c)). Apopylus Kolibáć [6]. Type species: Apopylus unumgarensis Kolibáč [6]. By monotypy.

Synapotypic Characteristics. The restriction of the tetranodal punctations to the posterior four-fifths of the elytral disc is a uniquely derived characteristic of this genus.

Diagnosis. The restriction of the tetranodal punctations to the posterior four-fifths of the elytral disc will conveniently distinguish the members of this genus within Tarsosteninae.

Description. Apopylus Kolibáč and its type species were adequately described by Kolibáč [6]. The metendosternite of Apopylus unumgarensis specimens have well-developed laminae.

Species Examined. Apopylus unumgarensis Kolibáč and one undescribed species.

4.5.5. Apteropilo Lea (Figures 5(a)-5(h), 6(e), 6(f), and 22(d)). Apteropilo Lea [14]. Type species: Apteropilo pictipes Lea [14]. By monotypy. Corporaal [5]. Kolibáč [6] (Pylusopsis Elston), Bartlett [15]. 
Synapotypic Characteristics. Pronotal disc with two glabrous tumescences, pronotal sides with two extraordinarily large setiferous punctations, metendosternite without furcal anterior plate.

Diagnosis. The combination of glabrous tumescences on the pronotal disc present, elytral punctations binodal, and each side of the pronotum with two large setiferous punctations will conveniently distinguish the members of this genus within Tarsosteninae.

Description. Size: length $3.5-6.0 \mathrm{~mm}$; width $1.2-2.0 \mathrm{~mm}$. Form: Figure 22(d) oblong short rectangulate, rarely hind body suboval, about 2.5 times longer than broad. Vestiture: disc of cranium and pronotum vested with pale setae, elytral disc vested with $1^{\circ}$ setae and shorter profusely distributed $2^{\circ}$ setae. Head (Figures 5(a) and 5(b)): cranium quadrate, frons wider than width of eye, indented with large setiferous punctations that give cranium rugose appearance, or cranial indentations small and widely separated; gula (Figure 5(a)), large, trapezoidal, sutures oblique, gular processes widely separated, processes in form of two setiferous tubercles; labrum short, deeply incised, transverse tormal processes not confluent, epipharyngeal plate very small; mandible (Figure 5(d)), body short, anterior, medial dens well developed, posterior dens not well developed, penicillus well developed; maxilla, laterolacinia present, terminal palpomere securiform; labium, ligula not deeply incised, terminal palpomere securiform; eyes small, coarsely faceted, ocular notch small; antenna (Figure 5(h)), capitate, capitulum lax or not, scape about as long as combined length of pedicel and antennomere 3, funicular antennomeres filiform, antennomeres 9 and 10 triangular, antennomere 11 ovoid. Thorax: pronotum (Figures 5(c) and 5(g)), transverse, disc with two glabrous tumescences that sometimes are confluent with other elevations, side margins with distinct tubercles, usually two round punctations particularly large near sides, rest of disc with large round setiferous punctations, dorsolateral ridge extends from posterior angle to anterior angle, surface coarse and fractured by coarse punctations, sclerotized region above pronotal projection glabrous, prebasal fissure well developed, prointercoxal process not expanded distally; pronotal projections short; elytron sculptured with large spheroid asetiferous punctations, latter seriate and binodal, $1^{\circ}$ setae always adjacent to asetiferous punctations, $2^{\circ}$ setae densely distributed, not arranged serially, epipleural fold laterally positioned, extended to elytral apex, anterior margin carinate; metathoracic wing (Figure 5(f)), rarely absent, wedge cell open; metendosternite (Figure 5(e)), with furcal lamina, furcal anterior plate absent; legs, tibial spur formula 0-2-1, tarsal pulvillar formula 3-3-3, unguis without denticle (Figure 6(f)). Abdomen: Aedeagus shorter than length of abdomen, phallobase reduced, lobate distally, lobes fimbriate; phallic lateral plates very broad, spicular plates narrowly triangular, acuminate, spicular apodemes not fused, intraspicular plate rod-shaped; ovipositor, ventral and dorsal laminae unilobed, laminal rod present; distal margin of pygidium not incised, distal margin of male sixth sternite slightly incised. Alimentary Canal: Not studied. Male mesodermal internal reproductive organs: not studied. Female mesodermal internal reproductive organs: Spermathecal capsule well sclerotized, tubular, elongate, spermathecal gland attached to apex of spermathecal capsule.

Distribution. The members of this genus have been found in southeastern and Western Australia and on Kings Island, off the Bass Strait.

Species Examined. Apteropilo chrysocome (Elston), A. pictipes Lea, A. raldae Bartlett, and A. volans Bartlett.

Notes. Bartlett [15] provided habitus illustrations of each species and drawings of male genitalia.

4.5.6. Blackburniella Chapin (Figures 7(a)-7(h), 12(a), 12(b), and 22(e)). Blackburniella Chapin [16]. Type species: Thanasimomorpha intricta Blackburn [17]. By original designation. Corporaal [5]. Matthews [18]. Kolibáč [6].

Erolestus Wolcott [19]. Synonymized by Wolcott, 1947.

Synapotypic Characteristics. Spermathecal duct very long, tuft of setae on elytral umbo, phallic apex extended.

Diagnosis. The tuft of black setae on the elytral umbo will distinguish the members of this genus from others in the subfamily.

Description. Size: length $4.2-8.0 \mathrm{~mm}$; width $1.2-2.0 \mathrm{~mm}$. Form: Figure 22(e), oblong long rectangulate, about 4 times longer than broad. Vestiture: disc of cranium and pronotum vested with pale setae, elytral disc vested with $1^{\circ}$ setae and shorter profusely distributed $2^{\circ}$ setae, elytral umbo covered with tuft of black setae, elytral setae very densely distributed in elytral apical half. Head (Figures 7(a), 7(b), and 12(a)): cranium quadrate, frons wider than width of eye, indented with large setiferous punctations that give cranium rugose appearance; gula (Figure $7(\mathrm{a})$ ), large, trapezoidal, sutures oblique, gular processes widely separated, processes in form of two setiferous tubercles; labrum short, deeply incised, transverse tormal processes confluent, epipharyngeal plate very small; mandible, body short, anterior, medial dens well developed, posterior dens not well developed, penicillus well developed; maxilla (Figure 12(b)), laterolacinia present, terminal palpomere securiform; labium, ligula not deeply incised, terminal palpomere securiform; eyes small, coarsely faceted, ocular notch large; antenna (Figure $7(\mathrm{~g})$ ), capitate, capitulum lax, somewhat narrow, scape about as long as combined length of pedicel and antennomere 3, funicular antennomeres subfiliform, capitular antennomeres somewhat narrow, antennomeres 9 and 10 triangular, antennomere 11 ovoid. Thorax: pronotum (Figures $7(\mathrm{c})$ and $7(\mathrm{~d})$ ), from subquadrate to longer than broad, disc indented with large setiferous punctations, side margins sinuous, rounded near middle, dorsolateral ridge spans posterior third of pronotal sides, ridge surface coarse, sclerotized 
region above pronotal projection glabrous, prebasal fissure shallow, prointercoxal process not expanded distally; pronotal projections short; elytron sculptured with large spheroid asetiferous punctations in basal half, punctations minute in distal half, punctations seriate in basal half, not binodal, $1^{\circ}$ setae always adjacent to asetiferous punctations, $2^{\circ}$ setae densely distributed, not arranged serially, epipleural fold laterally positioned, extended to elytral apical three-fourths, anterior margin carinate; metathoracic wing (Figure 7(f)), wedge cell open; metendosternite (Figure $7(\mathrm{e})$ ), with furcal lamina, furcal anterior plate prominent; legs, tibial spur formula 1-2-1, tarsal pulvillar formula 3-3-3, unguis without denticle. Abdomen: aedeagus shorter than length of abdomen, phallobase not reduced, lobate distally, lobes fimbriate; phallic lateral plates narrow, phallic apex extended, spicular plates very narrow, spicular apodemes fused at extremity, intraspicular plate rod-shaped; ovipositor, ventral and dorsal laminae unilobed, laminal rod present; distal margin of pygidium not incised, distal margin of male sixth sternite slightly incised. Alimentary canal: not studied. Male mesodermal internal reproductive organs: Not studied. Female mesodermal internal reproductive organs (Figure $7(\mathrm{~h})$ ): spermathecal capsule capitates, well sclerotized, spermathecal gland attached to base of spermathecal capsule, spermathecal duct very long, saccular bursa copulatrix present.

Distribution. The members of this genus have been found only in Australia.

Species Examined. Blackburniella intricata (Blackburn) and one new species.

Notes. Kolibáč [6] provided drawings of the male genitalia and female mesodermal reproductive organs.

4.5.7. Curacavi Solervicens (Figures 3(a)-3(h), 6(a) and 6(b)). Curacavi Solervicens [20].Type species: Curacavi dentatus Solervicens [20]. By monotypy.

Synapotypic Characteristics. Pronotal punctations elongate, epipleuron in ventral position.

Diagnosis. The serrulated lateral margins of the pronotum will distinguish the members of this genus within Tarsosteninae.

Description. Size: length $4.0 \mathrm{~mm}$; width $1.8 \mathrm{~mm}$. Form (Figure 3(a)): oblong rectangulate, about 3 times longer than broad. Vestiture: disc of cranium and pronotum vested with dark setae, elytral disc vested with $1^{\circ}$ setae and shorter sparsely distributed $2^{\circ}$ setae. Head (Figure 6(a)): cranium quadrate, frons much wider than width of eye, indented with small setiferous punctations and lager asetiferous punctations; gula large, trapezoidal, sutures oblique, gular processes widely separated, processes in form of two setiferous tubercles; labrum short, medial incision shallow, mandible, body short, anterior and medial dens well developed, posterior dens not well developed, penicillus well developed; maxilla, laterolacinia present, terminal palpomere subsecuriform; labium, ligula not deeply incised, terminal palpomere securiform; eyes very small, coarsely faceted, ocular notch large; antenna (Figure 3(d)), capitate, capitulum lax and narrow, scape about as long as combined length of pedicel and antennomere 3, funicular antennomeres filiform, capitular antennomeres narrow, antennomeres 9 and 10 near capitate, antennomere 11 ovoid. Thorax: pronotum (Figures 3(b), $3(\mathrm{c})$, and 6(b)), transverse, convex, lateral margins serrulated, sculptured with large round setiferous punctations at anterior of disc, punctations elongate in remainder of disc, prebasal fissure well developed, prointercoxal process not expanded distally; pronotal projections short; elytron sculptured with large spheroid asetiferous punctations, latter seriate and binodal, $1^{\circ}$ setae always adjacent to asetiferous punctations, $2^{\circ}$ setae present, arranged serially, epipleural fold ventrally positioned, extended to elytral apex, margin minutely serrulated, anterior margin carinate; metathoracic wing with open wedge cell; metendosternite (Figure 3(e)), with furcal lamina, furcal anterior plate large, transverse; legs, tibial spur formula 2-2-2, tarsal pulvillar formula 3-3-3, unguis without denticle. Abdomen: aedeagus as long as length of abdomen, phallobase lobate distally (Figure 3(g)), lobes acuminate, not fimbriate; phallic lateral plate not very broad (Figure $3(\mathrm{~h})$ ), acuminate, with preapical uncus, spicular plates slender, with lateral uncus, spicular apodemes not fused (Figure 3(f)), intraspicular plate rod-shaped; ovipositor, ventral and dorsal laminae unilobed, laminal rod present; distal margin of pygidium not incised, distal margin of male sixth sternite slightly incised. Alimentary canal: stomodaeal valve comprised of four primary lobes, dorsal lobe very broad and half as long as other three lobes. Male mesodermal internal reproductive organs: Not studied. Female mesodermal internal reproductive organs: spermathecal capsule well sclerotized, barrel shaped, spermathecal gland attached to apex of spermathecal capsule.

Distribution. The members of this genus have been found only in Chile.

Species Examined. This is a monotypic genus.

Notes. For illustrations see Solervicens [21].

4.5.8. Fallopylus gen. nov. (Figures $8(a)-8(j), 12(c), 12(d)$, 21(f), and 22(f)). Type species: Pylus pallipes MacLeay [22]. Kolibáč [6].

Synapotypic Characteristics. Bursal sclerites cyclic.

Diagnosis. Blackburniella Chapin, Tarsostenodes Blackburn, Tarsostenus Spinola, and Fallopylus, gen. nov., are all characterized by a 1-2-1 tarsal spur formula. However, in specimens of Fallopylus there is a distinct tubercle on the lateral margins of the pronotum, which is not the case in specimens of the other three aforementioned genera. 
Description. Size: length $4.0-7.5 \mathrm{~mm}$; width $1.4-3.2 \mathrm{~mm}$. Form (Figure 22(f)): oblong short rectangulate, about 3 times longer than broad. Vestiture: disc of cranium and pronotum vested with pale setae, elytral disc vested with $1^{\circ}$ setae and shorter $2^{\circ}$ setae. Head (Figures 8(a) and 8(b)): cranium quadrate, frons slightly wider than width of eye, indented with very small setiferous punctations; gula (Figure 8(a)), large, trapezoidal, sutures oblique, gular processes widely separated, processes in form of two setiferous tubercles; labrum short, deeply incised, transverse tormal processes confluent, epipharyngeal plate very small; mandible (Figure $8(\mathrm{~g})$ ), body long, anterior and medial dens well developed, posterior dens not well developed, penicillus well developed; maxilla, laterolacinia present, terminal palpomere securiform or subsecuriform; labium, ligula deeply incised, terminal palpomere securiform; eyes large, coarsely faceted, ocular notch small; antenna (Figure 8(e) and 21(f)), capitate, capitulum lax, scape about as long as combined length of pedicel and antennomere 3, funicular antennomeres subfiliform, capitular antennomeres expanded, antennomeres 9 and 10 capitate, antennomere 11 ovoid, rarely acuminate. Thorax: pronotum (Figures 8 (c) and $8(d)$ ), transverse, disc indented with small setiferous punctations, lateral margins with tubercle sinuous, dorsolateral ridge extends from posterior angle to anterior angle, not fractured by coarse punctations, prebasal fissure prominent, prointercoxal process expanded distally; pronotal projections long; elytron sculptured with small or large bimodal asetiferous punctations, punctations seriate and extend to elytral apex, $1^{\circ}$ setae always adjacent to asetiferous punctations, $2^{\circ}$ setae sparsely distributed, arranged serially, epipleural fold laterally positioned, narrowed to elytral apex three, anterior margin carinate; metathoracic wing (Figure $8(\mathrm{~h})$ ), wedge cell closed; metendosternite (Figure 8(f)), with furcal lamina, furcal anterior plate prominent; legs, tibial spur formula 12-2, tarsal pulvillar formula 3-3-3, unguis without denticle. Abdomen: aedeagus (Figure $8(j)$ ), shorter than length of abdomen, phallobase reduced, lobate and narrowed distally, lobes not fimbriate; phallobasic rod transverse, phallic lateral plates very spinous, phallic apex minute, spicular plates very narrow (Figure 8(i)), spicular apodemes not fused at extremity, intraspicular plate rod shaped; ovipositor, ventral and dorsal laminae unilobed, laminal rod present; distal margin of pygidium not incised, distal margin of male sixth sternite slightly incised. Alimentary canal: not studied. Male mesodermal internal reproductive organs: not studied. Female mesodermal internal reproductive organs: spermathecal capsule ovoid, well sclerotized, spermathecal gland attached to base of spermathecal capsule, spermathecal duct long, saccular bursa copulatrix present, with cyclic basal sclerites.

Distribution. The members of this genus have been found only in Australia.

Species Examined. Fallopylus pallipes (MacLeay) (new combination) and three new undescribed species.
Etymology. The generic name Fallopylus stems from the Latin fallo (=deceive) and the name of the genus Pylus Newman.

Notes. Kolibáć [6] provides drawings of the female mesodermal reproductive organs.

4.5.9. Globoclava gen. nov. (Figure 22(g)). Type species: Pilus (=Pylus) quadrimaculata Chevrolat [23]. Shifting Pilus quadrimaculata Chevrolat from synonymy to a valid species of Globoclava represents a new status and new combination.

Synapotypic Characteristics. Last antennomere very large.

Diagnosis. The extensively globose development of the last antennomere will distinguish the members of this genus from other genera.

Description. Size: length $4.0-5.5 \mathrm{~mm}$; width $1.2-1.6 \mathrm{~mm}$. Form (Figure 22(g)): oblong short rectangular, about 3 times longer than broad. Vestiture: disc of cranium and pronotum vested profusely with erect setae, elytral disc vested with tall erect setae and shorter decumbent setae. Head: cranium quadrate, frons much wider than width of eye, indented with large setiferous punctations; gula large, trapezoidal, sutures oblique, gular processes widely separated, processes in form of two setiferous tubercles; labrum short, deeply incised, transverse tormal processes confluent, epipharyngeal plate very small; mandible, body short, anterior and medial dens well developed, posterior dens not well developed, penicillus well developed; maxilla, laterolacinia not studied, terminal palpomere subsecuriform; labium, ligula not incised, terminal palpomere subsecuriform; eyes large, finely faceted, ocular notch large; antenna, capitate, capitulum compact, scape about as long as combined length of pedicel and antennomere 3, funicular antennomeres filiform, capitular antennomeres expanded, antennomeres 9 and 10 expanded, antennomere 11 very large and ovoid. Thorax: pronotum quadrate, disc indented profusely with large setiferous punctations, lateral margins convex, lateral tubercle poorly developed, dorsolateral ridge extends from posterior angle to anterior angle, not fractured and with smooth surface, sclerotized region above pronotal projection glabrous, prebasal fissure shallow, prointercoxal process expanded distally; pronotal projections short; elytron sculptured with asetiferous punctations, punctations subseriate, epipleural fold laterally positioned, narrowed at elytral posterior two-thirds, anterior margin carinate; metathoracic wing not studied; metendosternite not studied; legs, tibial spur formula 0-1-1, tarsal pulvillar formula 3-3-3, pulvillus of metabasitarsomere very reduced, unguis with denticle. Abdomen: not examined. Alimentary canal: not studied. Male mesodermal internal reproductive organs: not studied. Female mesodermal internal reproductive organs: not studied.

Distribution. Known only from South Africa. 


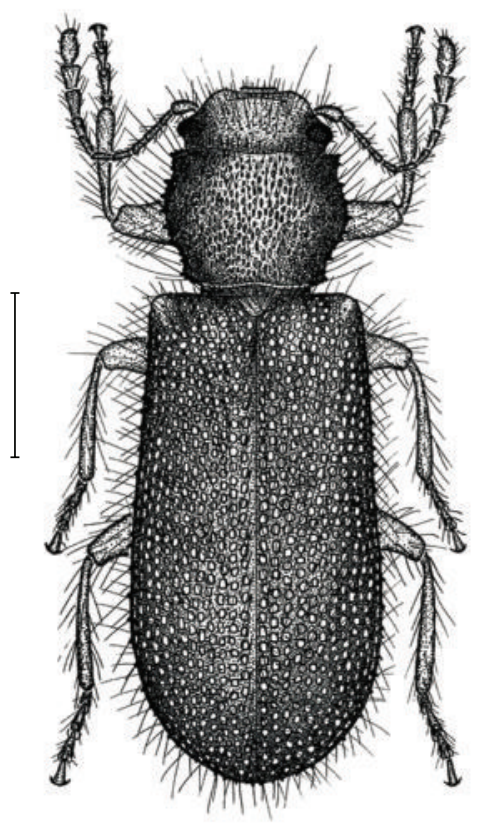

(a)

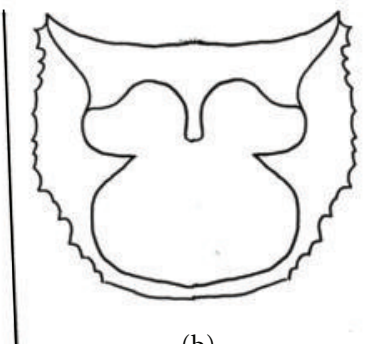

(b)

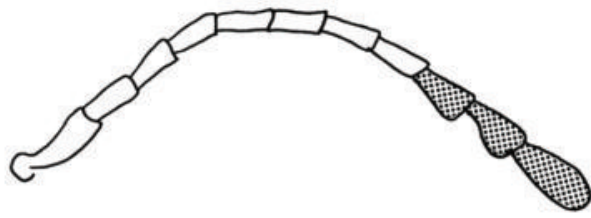

(d)

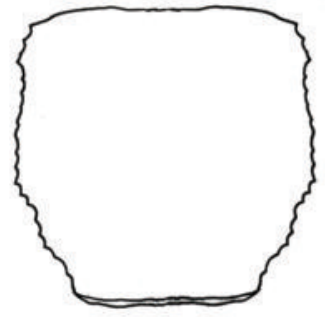

(c)

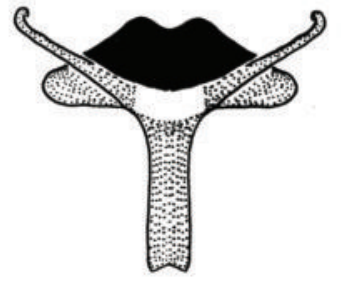

(e)
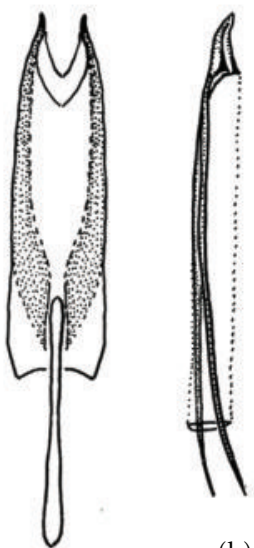

(h)

Figure 3: Various organs of Curacavi dentatus. (a) Habitus. (b, c) Thorax ((b) ventral, (c) dorsal). (d) Antenna. (e) Metendosternite. (f) Spiculum. (g) Tegmen. (h) Phallus.

Species Examined. Globoclava anthicides (Newman) (new combination).

Etymology. The generic name Globoclava stems from the Latin globus (=sphere) and the Latin clavus (= nail). I refer to the shape of the antenna in this beetle.

4.5.10. Neopylus Solervicens (Figures 9, 10, 12(e), and 22(h)). Neopylus Solervicens [24]. Type species: Neopylus nahuelbutensis Solervicens [24].

Synapotypic Characteristics. Pronotal and elytral disc vested with small white setal wisps.
Diagnosis. The small wisps of white setae on the dorsum of these beetles will distinguish them from superficially similar specimens of the Australian genus Pylus Newman.

Description. Size: length $9.0-10.0 \mathrm{~mm}$; width $3.5-4.0 \mathrm{~mm}$. Form (Figure 9): oblong long rectangulate, robust about 3 times longer than broad. Vestiture: disc of cranium vested profusely with white recumbent setae, pronotum and elytral disc vested with small wisps of white setae pale setae, elytral disc vested with $1^{\circ}$ setae and shorter $2^{\circ}$ setae. Head (Figures 10(a), 10(b), and 12(e)): cranium quadrate, frons wider than width of eye, indented with large setiferous punctations that give cranium rugose appearance; gula (Figure 10(a)), large, trapezoidal, sutures oblique, 


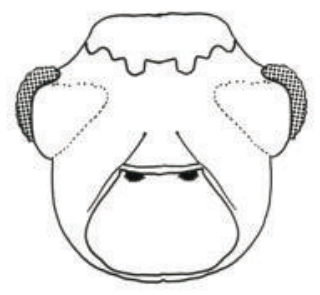

(a)

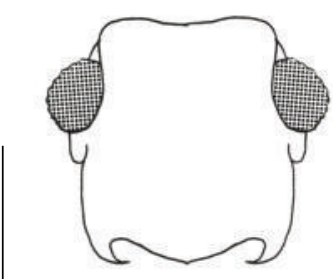

(b)

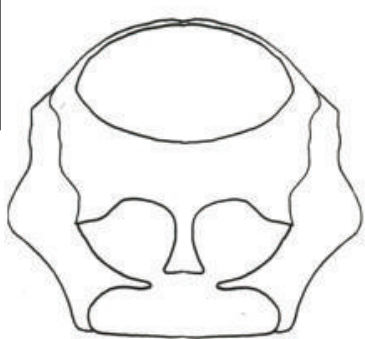

(c)

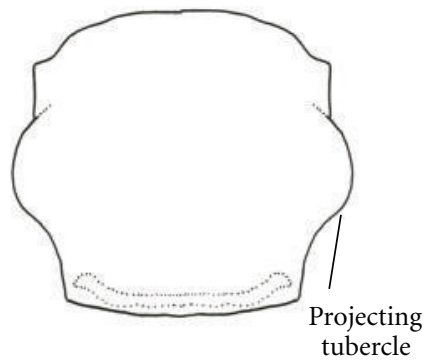

(d)

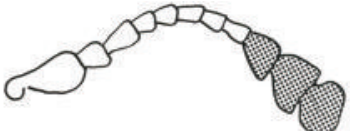

(e)

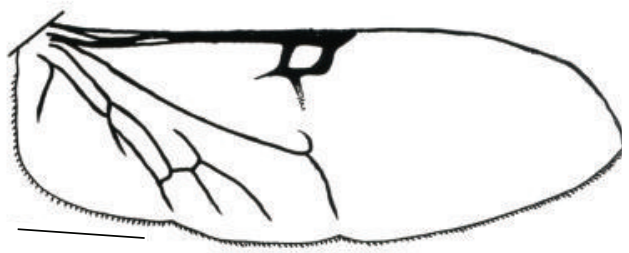

(f)

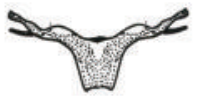

(g)

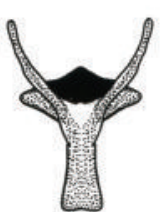

(h)

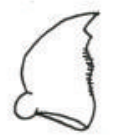

(j)
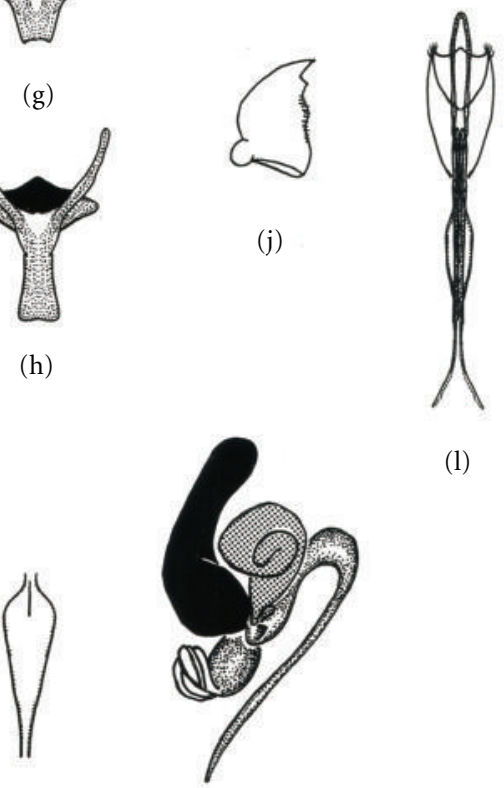

(1) (i)

(k)

Figure 4: Various organs. (a)-(g) and (h)-(l) of Pseudopylus okei. (a, b) Head ((a) ventral, (b) dorsal). (c, d) Pronotum ((c) ventral, (d) dorsal). (e) Antenna. (f) Metathoracic wing. (g) Metendosternite. (h) Metendosternite of Apopylus unumgarensis. (i) Spiculum. (j) Mandible. (k) Male mesodermal internal reproductive organs. (l) Aedeagus.

gular processes widely separated, processes in form of two setiferous tubercles; labrum (Figure 10(j)), short, not deeply incised, transverse tormal processes confluent, epipharyngeal plate very small; mandible (Figure 10(k)), body short, anterior, medial dens well developed, posterior dens not well developed, penicillus well developed; maxilla (Figure 10(i)), laterolacinia present, terminal palpomere securiform; labium (Figure 10(g)), ligula not deeply incised, terminal palpomere securiform; eyes small, coarsely faceted, ocular notch large; antenna (Figure 10(f)), capitate, capitulum lax, somewhat narrow, scape about as long as combined length of pedicel and antennomere 3, funicular antennomeres subfiliform, capitular antennomeres somewhat narrow, antennomeres
9 and 10 triangular, antennomere 11 somewhat truncate. Thorax: pronotum (Figures 10(c) and 10(d)), transverse, disc indented with large setiferous punctations, central lineal fissure, and with small elevations, side margins with distinct tubercle, dorsolateral ridge extends from posterior angle to anterior angle, not fractured but made coarse by coarse punctations, sclerotized region above pronotal projection with setiferous punctations at base, glabrous in remainder, prebasal fissure shallow, prointercoxal process expanded distally; pronotal projections long; elytron sculptured with large spheroid asetiferous punctations, punctations smaller near elytral apex, punctations not seriate, $1^{\circ}$ setae always adjacent to asetiferous punctations, $2^{\circ}$ setae not 


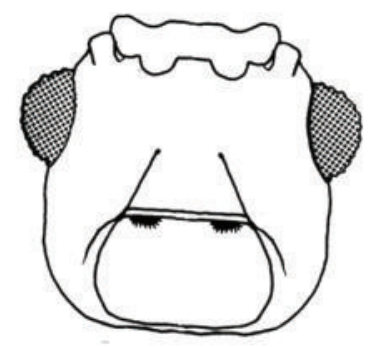

(a)

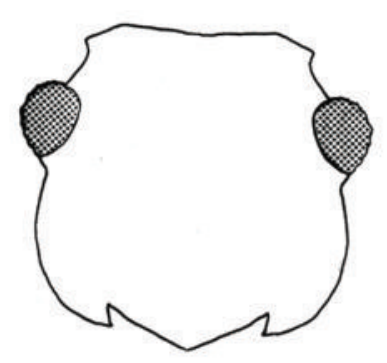

(b)

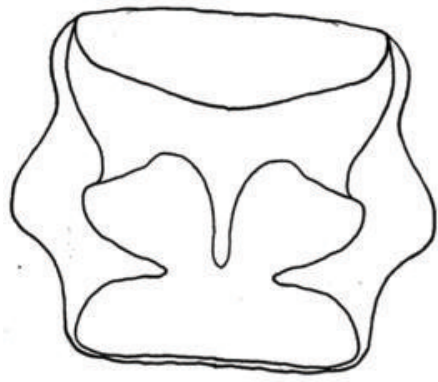

(c)

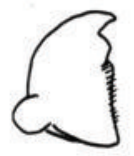

(d)

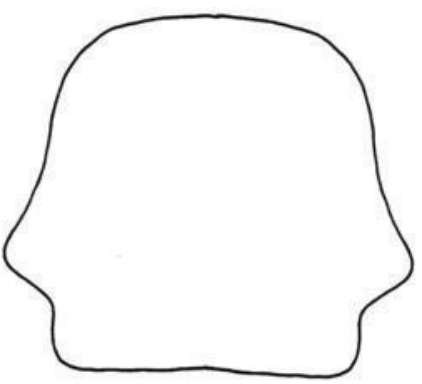

(g)

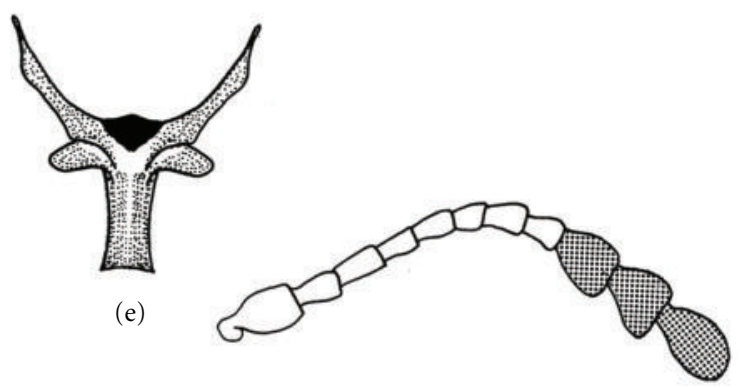

(h)

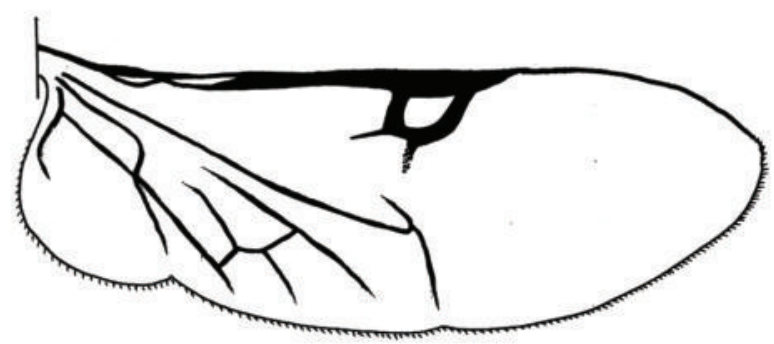

(f)

Figure 5: Various organs of Apteropilo chrysocome. (a, b) Head ((a) ventral, (b) dorsal). (c) Pronotum (ventral). (d) Mandible. (e) Metendosternite. (f) Metathoracic wing. (g) Pronotum (dorsal). (h) Antenna.

arranged serially, epipleural fold laterally positioned, narrow near elytral apex, anterior margin carinate; metathoracic wing (Figure 10(e)), wedge cell closed; metendosternite (Figure 10(h)), with furcal lamina, furcal anterior plate prominent; legs, tibial spur formula 1-2-2, tarsal pulvillar formula 3-3-3, unguis without denticle. Abdomen: aedeagus (Figures $10(\mathrm{~m})$ and $10(\mathrm{n})$ ), shorter than length of abdomen, phallobase not reduced, lobate distally, lobes not fimbriate; phallic lateral plates broad, phallic apex stout, spicular plates narrow (Figure 10(1)), slightly acuminate, spicular apodemes fused, intraspicular plate rod shaped; ovipositor, ventral and dorsal laminae unilobed, laminal rod present; distal margin of pygidium not incised, distal margin of male 6th sternite slightly incised. Alimentary canal: not studied.
Male mesodermal internal reproductive organs: not studied. Female mesodermal internal reproductive organs: saccular bursa copulatrix present, bursa with two basal sclerites.

Distribution. The members of this genus have been found only in Chile.

Species Examined. This is a monotypic genus.

4.5.11. Parapylus Blackburn (Figures 11(a)-11(l), 12(f), and 22(i)). Parapylus Blackburn [17]. Type species: Parapylus bicinctus Newman [25]. By monotypy. 


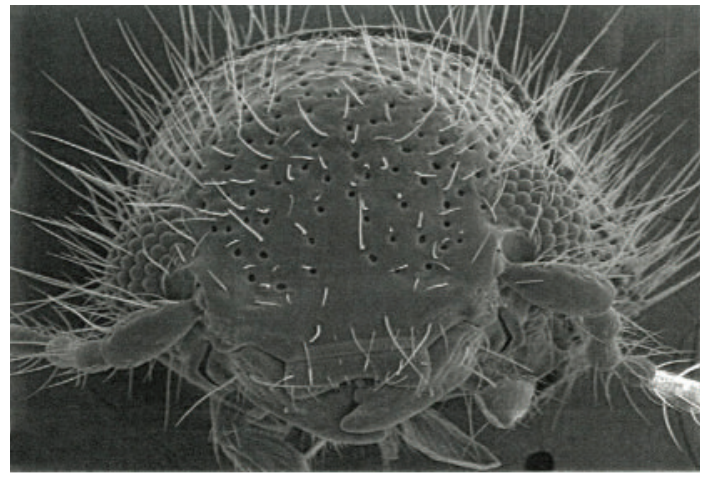

(a)

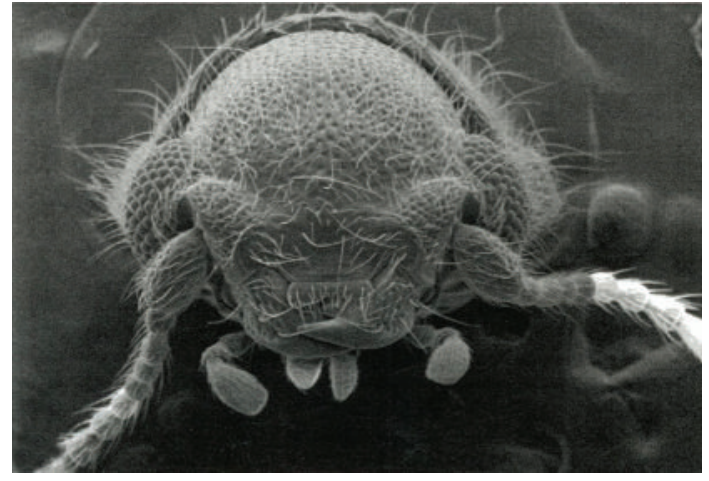

(c)

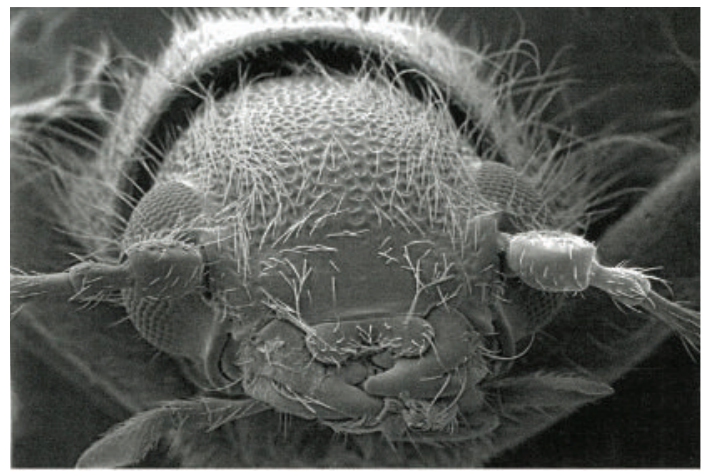

(e)

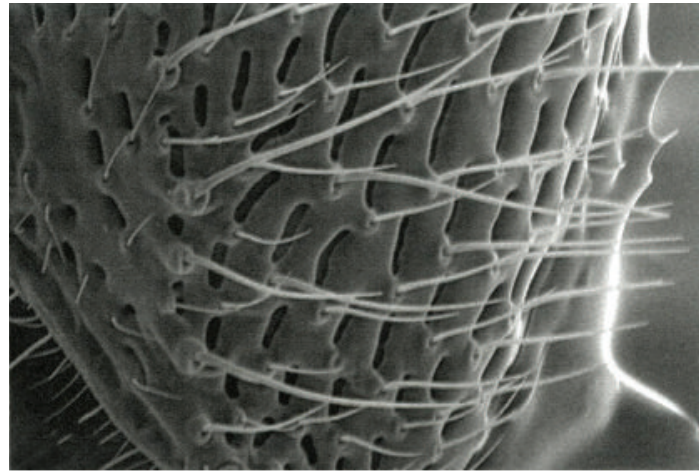

(b)

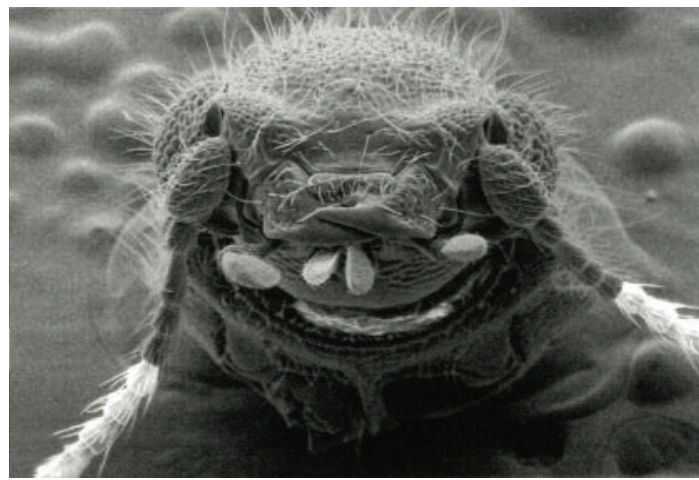

(d)

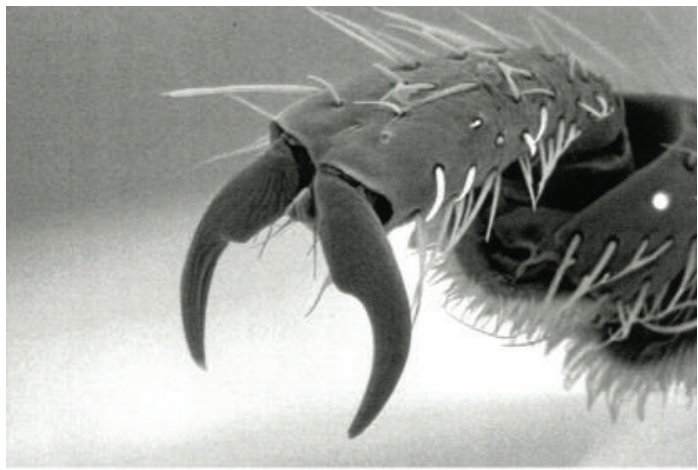

(f)

Figure 6: Various organs. (a, b) Curacavi dentatus ((a) head, (b) pronotal disc). (c, d) Pseudopilus okei ((c) head, (d) mouthparts). (e, f) Apteropilo chrysocome ((e) head, (f) protarsus).

Synapotypic Characteristics. Tarsal spur formula 2-2-2, elytral disc vested with transverse setal fascia, only apex of spermathecal capsule visibly sclerotized.

Diagnosis. Transverse setal fascia on the elytral disc and a tarsal formula of 2-2-2.

Description. Size: length $4.0-7.0 \mathrm{~mm}$; width $1.8-3.8 \mathrm{~mm}$. Form (Figure 22(i)): oblong short rectangulate, robust, about 2 times longer than broad. Vestiture: disc of cranium vested profusely with dark setae, pronotum and elytral vested profusely vested with dark setae, elytral disc vested with $1^{\circ}$ setae and shorter $2^{\circ}$ setae, elytral disc narrow fascia of white setae. Head (Figures 11(a), 11(b), 12(f)): cranium quadrate, frons wider than width of eye, indented with large setiferous punctations that give cranium rugose appearance; gula (Figure 11(a)), large, trapezoidal, sutures oblique, gular processes widely separated, processes in form of two setiferous tubercles; labrum short, deeply incised, transverse tormal processes confluent, epipharyngeal plate not discernible; mandible, body long, anterior, medial dens well developed, posterior dens not well developed, penicillus well developed; maxilla (Figure 11(i)), laterolacinia present, terminal subdigitiform; labium (Figure 11(h)), ligula deeply incised, terminal palpomere securiform; eyes small, coarsely faceted, ocular notch large; antenna (Figure 11(e)), capitate, capitulum compact, wide, scape about as long as combined 


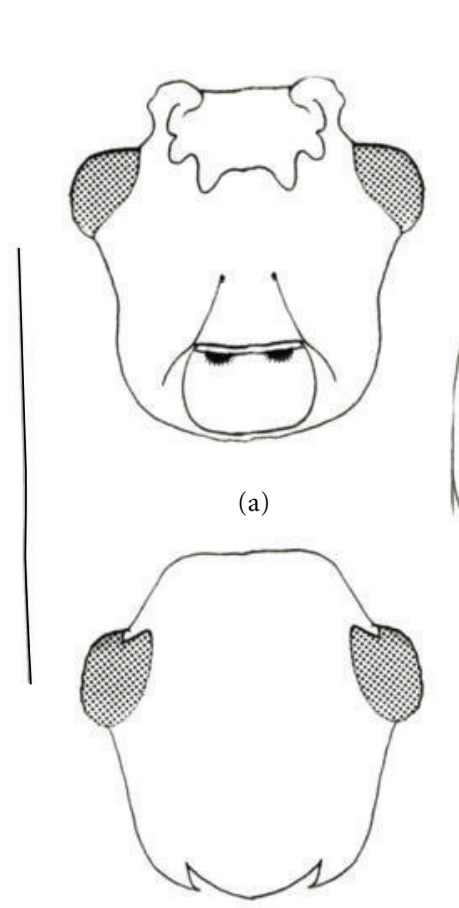

(b)

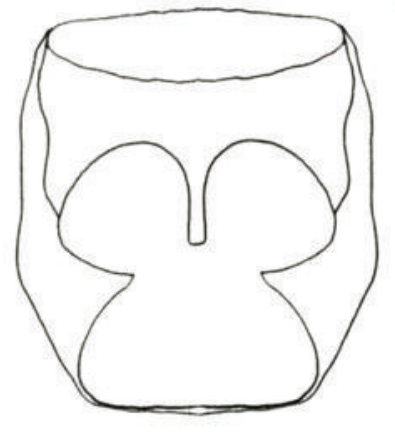

(c)

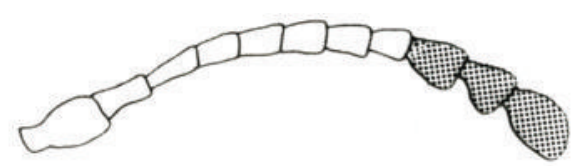

(g)

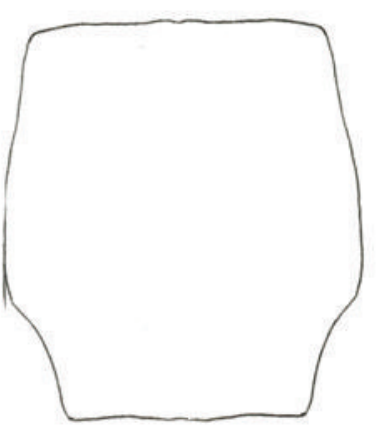

(d)

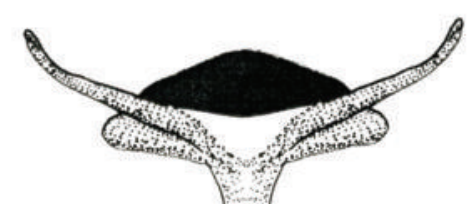

1

(e)

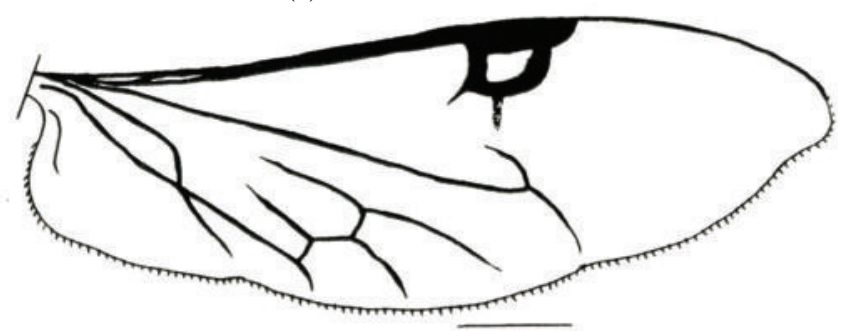

(f)

Figure 7: Various organs of Blackburniella intricata. (a, b) Head ((a) ventral, (b) dorsal). (c, d) Pronotum ((c) ventral, (d) dorsal). (e) Metendosternite. (f) Metathoracic wing. (g) Antenna. (h) Female mesodermal organs.

length of pedicel and antennomere 3, funicular antennomeres subfiliform, capitular antennomeres wide, antennomeres 9 and 10 expanded laterally, antennomere 11 transverse. Thorax: pronotum (Figures 11(c) and 11(d)), transverse, disc indented with large setiferous punctations, with central linear fissure, and small paralateral elevations, side margins with distinct tubercle, dorsolateral ridge extends from posterior angle to anterior angle, not fractured but made coarse by coarse punctations, sclerotized region above pronotal projection setose, not glabrous, prebasal fissure well developed, prointercoxal process expanded distally; pronotal projections long; elytron sculptured with large spheroid asetiferous punctations, punctations smaller in elytral apical half, punctations not seriate, $1^{\circ}$ setae adjacent to asetiferous punctations, $2^{\circ}$ setae not arranged serially, epipleural fold laterally positioned, narrows towards elytral apex, anterior margin carinate; metathoracic wing (Figure 11(f)), wedge cell closed; metendosternite (Figure 11(g)), with furcal lamina, furcal anterior plate prominent; legs, tibial spur formula 2-2-2, tarsal pulvillar formula 3-3-3, unguis without denticle. Abdomen: aedeagus shorter than length of abdomen, phallobase reduced, lobate distally, lobes fimbriate, phallobasic rod bifid distally; phallic lateral plates narrow, phallic apex minute, spicular plates triangular (Figure 11(j)), spicular apodemes not fused, intraspicular plate rod shaped; ovipositor, ventral and dorsal laminae unilobed, laminal rod present; distal margin of pygidium not incised, distal margin of male 6th sternite slightly incised. Alimentary canal: not studied. Male mesodermal internal reproductive organs (Figure 11(k)): two pairs of accessory glands, lateral pair divided. Female 


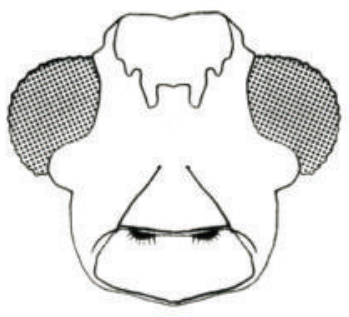

(a)

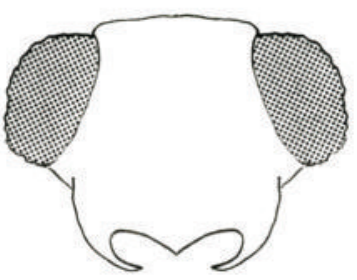

(b)

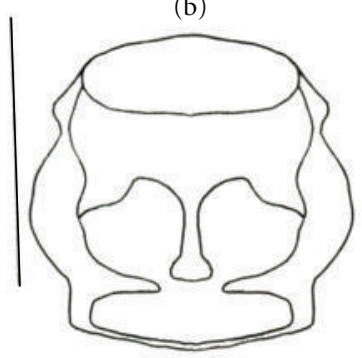

(c)

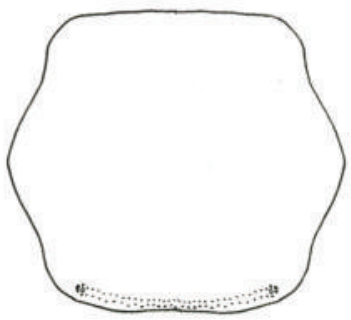

(d)

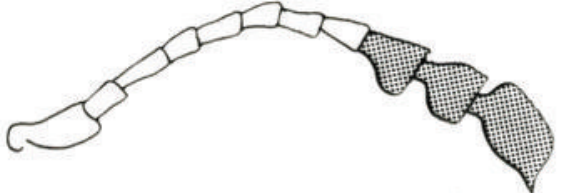

(e)

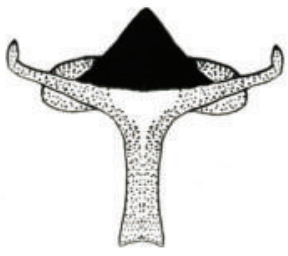

(f)

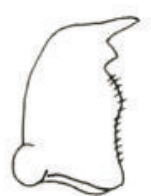

(g)

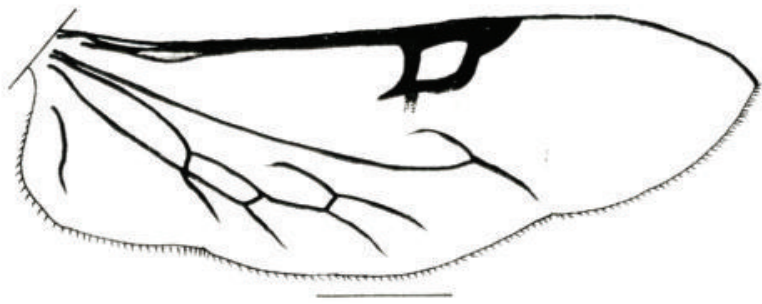

(h)

Figure 8: Various organs of Fallopylus pallipes. (a, b) Head ((a) ventral, (b) dorsal). (c, d) Pronotum ((c) ventral, (d) dorsal). (e) Antenna. (f) Metendosternite. (g) Mandible. (h) Metathoracic wing. (i) Spiculum. (j) Aedeagus.

mesodermal internal reproductive organs (Figure 11(1)): saccular bursa copulatrix present, bursa with two basal sclerites, only apex of spermathecal capsule sclerotized, spermathecal gland attached to apex of spermatheca.

Distribution. The members of this genus have been found only in Australia.

Species Examined. Parapylus bicinctus Newman and P. sedlaceki (Kolibáč) (new combination).

Notes. As Parapylus Blackburn Newman is characterized by having a tarsal spur formula of 2-2-2 its two species cannot be retained in Pylus Newman, which is characterized by a tarsal formula of 2-2-1. Other differences involve smaller ommatidia and the elytra of Parapylus have short longitudinal ridges on the posterior half of the elytral disc, the elytra are setose-fascia and show a basal umbo. Kolibác [6] provides illustrations of various organs of Parapylus bicinctus Newman.

4.5.12. Pseudopylus, gen. nov. (Figures 4(a)-4(g), 4(i)-4(l), $6(c), 6(d)$, and $23(a))$.

Type Species. Pylus okei Elston [26]. Kolibáč [6].

Synapotypic Characteristics. Tibial spur formula 0-0-0. 


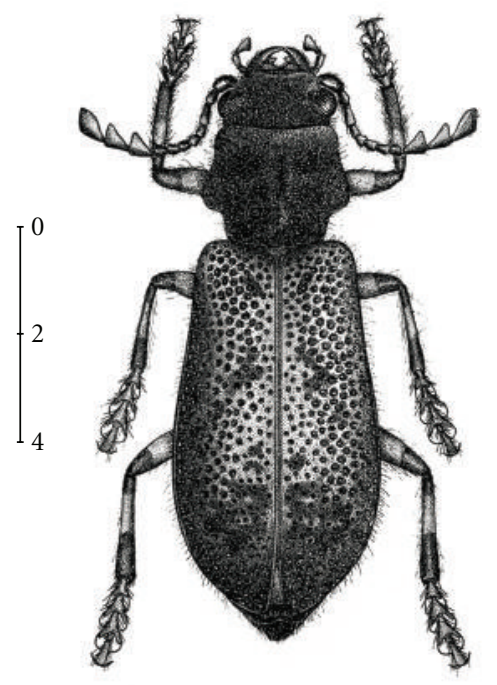

Figure 9: Habitus of Neopylus nahuelbutensis.

Diagnosis. The absence of glabrous tumescences on the pronotal disc of specimens of Pseudopylus will distinguish them from those of Apteropilo.

Size: length $3.8-7.0 \mathrm{~mm}$; width $1.4-3.6 \mathrm{~mm}$. Form (Figure 23(a)): oblong short rectangulate, about 3 times longer than broad. Vestiture: disc of cranium and pronotum vested with pale setae, elytral disc vested with $1^{\circ}$ setae and shorter profusely distributed $2^{\circ}$ setae. Head (Figures 4(a), $4(\mathrm{~b})$, and 6(c)): cranium quadrate, frons wider than width of eye, indented with large setiferous punctations that give cranium rugose appearance; gula (Figure 4(a)) large, trapezoidal, sutures oblique, gular processes widely separated, processes in form of two setiferous tubercles; labrum short, deeply incised, transverse tormal processes not confluent, epipharyngeal plate very small; mandible (Figure 4(j)), body short, anterior, medial dens well developed, posterior dens not well developed, penicillus well developed; maxilla (Figure 6(d)), laterolacinia present, terminal palpomere sub securiform; labium, ligula not deeply incised, terminal palpomere subsecuriform; eyes small, coarsely faceted, ocular notch small; antenna (Figure 4(e)), capitate, capitulum compact, scape about as long as combined length of pedicel and antennomere 3, funicular antennomeres subfiliform, capitular antennomeres wide, antennomeres 9 and 10 triangular, antennomere 11 ovoid. Thorax: pronotum (Figures 4(c), and 4(d)), transverse, side margins with distinct tubercles, disc with large oblong or round setiferous punctations, dorsolateral ridge extends from posterior angle to anterior angle, surface coarse and fractured by coarse punctations, prebasal fissure well developed, prointercoxal process expanded distally; pronotal projections long; elytron sculptured with large spheroid asetiferous punctations, latter seriate, punctations bimodal, $1^{\circ}$ setae always adjacent to asetiferous punctations, $2^{\circ}$ setae arranged serially, epipleural fold laterally positioned, extended to elytral posterior four-fifths, anterior margin carinate; metathoracic wing (Figure 4(f)), rarely absent, when present wedge cell closed; metendosternite (Figure $4(\mathrm{~g})$ ), with furcal lamina, furcal lamina may be reduced in size, furcal anterior plate present or absent; legs, tibial spur formula 0-0-0, tarsal pulvillar formula 3-3-3, unguis without denticle. Abdomen: aedeagus (Figure 4(1)), as long as length of abdomen, phallobase reduced, lobate distally, lobes fimbriate; phallic lateral plates very narrow, particularly long, spicular plates very narrow, spicular apodemes not fused (Figure 4(i)), intraspicular plate rod shaped; ovipositor, ventral and dorsal laminae unilobed, laminal rod present; distal margin of pygidium not incised, distal margin of male sixth sternite slightly incised. Alimentary canal: six malpighian tubules. Male mesodermal internal reproductive organs (Figure $4(\mathrm{k})$ ): two pairs of accessory glands, medial gland coiled, vesiculated at base, lateral glad digitiform, seminal vesicle bulbous, testis very small. Female mesodermal internal reproductive organs: spermathecal capsule well sclerotized, spermathecal gland attached near base of spermathecal capsule, saccular bursa copulatrix present, two denticulated basal bursal sclerites present.

Distribution. The members of this genus have been found only in Australia.

Species Examined. Pseudopylus okei (Elston) (new combination) and three undescribed species.

Etymology. The generic name Pseudopylus stems from the Greek pseudo (=fallacy) and the name of the genus Pylus Newman.

Notes. Kolibáč [6] provides excellent drawings of the aedeagus and female mesodermal internal reproductive organs of Pseudopylus okei (Elston). Note the poor development of the metendosternite of P. okei (Elston) (Figure 4(g)) a species in which the metathoracic wings are absent. The metendosternite is well developed in A. unumgarensis Kolibáč (Figure 4(h)) whose specimens show well-developed membranous wings.

4.5.13. Pylus Newman (Figures 13(a)-13(j), 16(a), 16(b), and 23(b)). Pylus Newman [27]. Type species: Pylus fatuus Newman [27]. Corporaal [5].

Ylotis Spinola [28]. Synonymized by Corporaal, 1950.

Ylotis Spinola [12]. Synonymized by Corporaal, 1950.

Synapotypic Characteristics. Spermathecal gland very long (Figure 13(i)).

Diagnosis. Within Tarsosteninae elytral disc punctations are serially rowed to the elytral apex in specimens of Apopylus Kolibáć, Fallopylus gen. nov., and in Pylus Newman. However, the tibial spur formula is 2-2-2 in Pylus Newman, 0-0-0 in Apopylus Kolibáč, and 1-2-1 in Fallopylus gen. nov. 


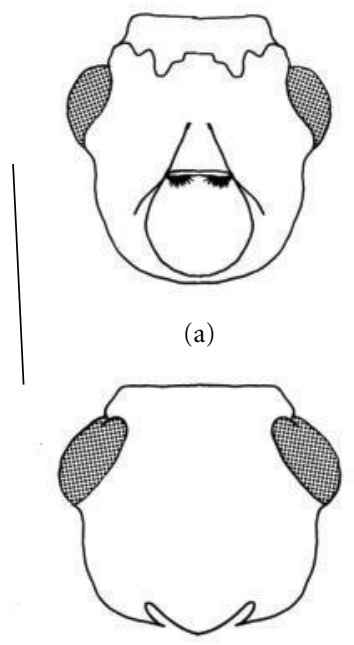

(b)

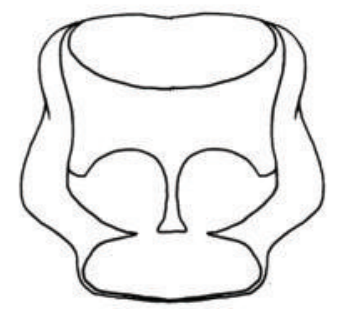

(c)

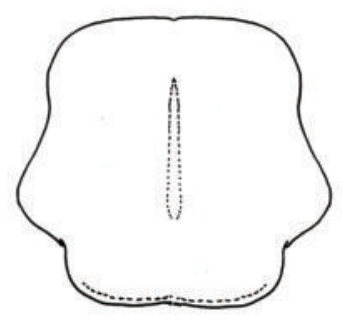

(d)

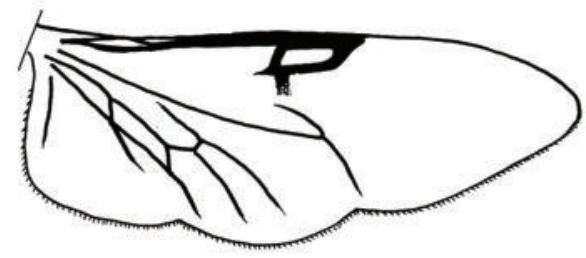

(e)

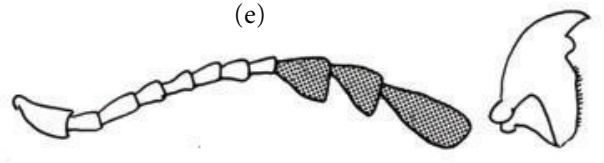

(f)

(k)

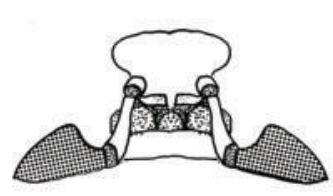

(g)

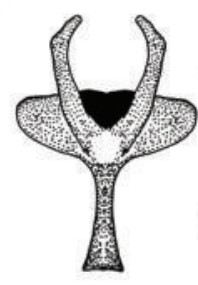

(h)

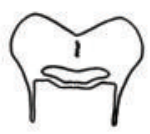

(j)

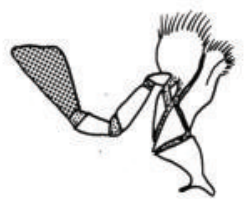

(i)

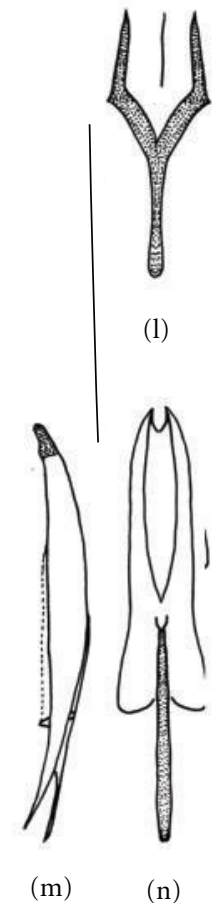

(n)

FIgURE 10: Various organs of Neopylus nahuelbutensis. (a, b) Head ((a) ventral, (b) dorsal). (c, d) Thorax ((c) ventral, (d) dorsal). (e) Metathoracic wing. (f) Antenna. (g) Labium. (h) Metendosternite. (i) Maxilla. (j) Labrum. (k) Mandible. (l) Spiculum. (m) Phallus. (n) Tegmen.

Description. Size: length $5.0-15.5 \mathrm{~mm}$; width $2.0-5.2 \mathrm{~mm}$. Form (Figure 23(b)): oblong long rectangulate, robust, about 3 times longer than broad. Vestiture: disc of cranium vested profusely with dark setae, pronotum and elytral vested profusely vested with dark setae, elytral disc vested with short $1^{\circ}$ setae and shorter $2^{\circ}$ setae. Head (Figures 13(a), 13(b), and 16(a)): cranium quadrate, frons wider than width of eye, indented with large setiferous punctations that give cranium rugose appearance; gula (Figure 13(a)), large, trapezoidal, sutures oblique, gular processes widely separated, processes in form of two setiferous tubercles; labrum short, not deeply incised, transverse tormal processes confluent, epipharyngeal plate small; mandible, body long, anterior, medial dens well developed, posterior dens not well developed, penicillus well developed; maxilla (Figure 16(b)), laterolacinia present, terminal subsecuriform; labium (Figure 16(b)), ligula deeply incised, terminal palpomere securiform; eyes large, coarsely faceted, ocular notch large; antenna (Figure 13(e)), capitate, capitulum compact, wide, scape about as long as combined length of pedicel and antennomere 3, funicular antennomeres subfiliform, capitular antennomeres wide, antennomeres 9 and 10 expanded laterally, antennomere 11 transverse. Thorax: pronotum (Figures 13(c) and 13(d)), transverse, disc indented with large setiferous punctations, with central fissure, and small paralateral elevations, side margins with distinct tubercle at middle and knob at 


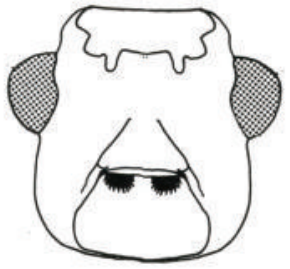

(a)

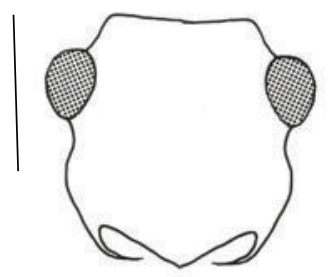

(b)

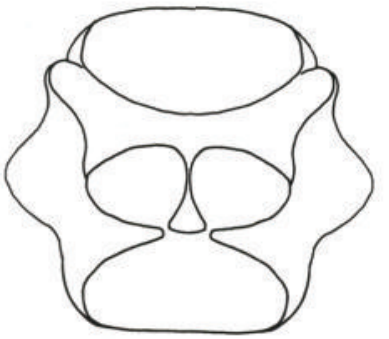

(c)

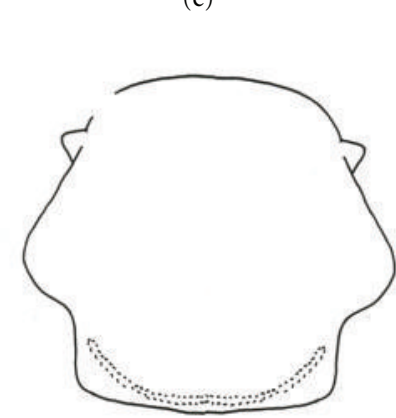

(d)

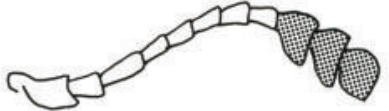

(e)

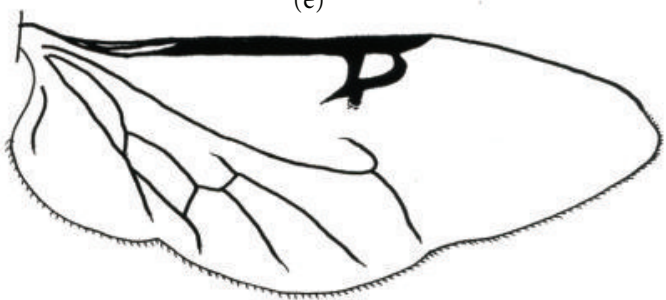

(f)

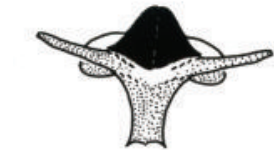

(g)

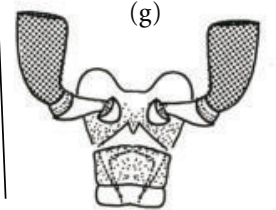

(h)

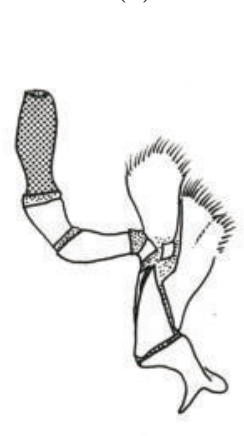

(i)

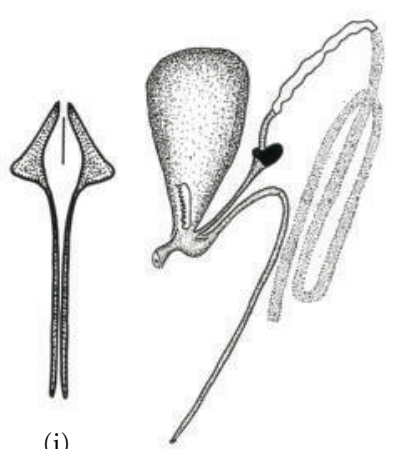

(1)

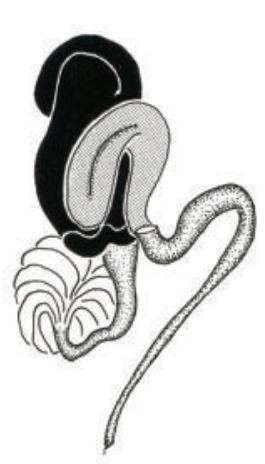

(k)

Figure 11: Various organs of Parapylus bicinctus. (a, b) Head ((a) ventral, (b) dorsal). (c, d) Pronotum ((c) ventral, (d) dorsal). (e) Antenna. (f) Metathoracic wing. (g) Metendosternite. (h) Labium. (i) Maxilla. (j) Spiculum. (k) Male mesodermal reproductive organs. (l) Female mesodermal reproductive organs.

anterior angles, dorsolateral ridge extends from posterior angle to anterior angle, not fractured but made coarse by coarse punctations, sclerotized region above pronotal projection not glabrous, setose, prebasal fissure well developed, prointercoxal process expanded distally; pronotal projections long; elytron sculptured with large binoded asetiferous punctations, punctations seriate, extend to elytral apex seriate, $1^{\circ}$ setae adjacent to asetiferous punctations, $2^{\circ}$ setae serially arranged, epipleural fold laterally positioned, narrows towards elytral apex, anterior margin carinate; metathoracic wing (Figure 13(f)), wedge cell closed; metendosternite with furcal lamina, furcal anterior plate prominent; legs, first tarsomere may be slender, acuminate and extended towards second tarsomere, tibial spur formula 2-2-1, tarsal pulvillar formula 3-3-3, unguis without denticle. Abdomen: aedeagus (Figures 13(h) and 13(j)), shorter than length of abdomen, phallobase reduced, lobate distally, lobes fimbriate, phallobasic rod not bifid distally; phallic lateral plates narrow, phallic apex minute, spicular plates narrow, with small rounded lateral extension, spicular apodemes not fused (Figure 13(g)), intraspicular plate rod shaped; ovipositor, ventral and dorsal laminae unilobed, laminal rod present; distal margin of pygidium not incised, distal margin of male 6th sternite slightly incised. Alimentary canal: not studied. Male mesodermal internal reproductive organs: not studied. Female mesodermal internal reproductive 


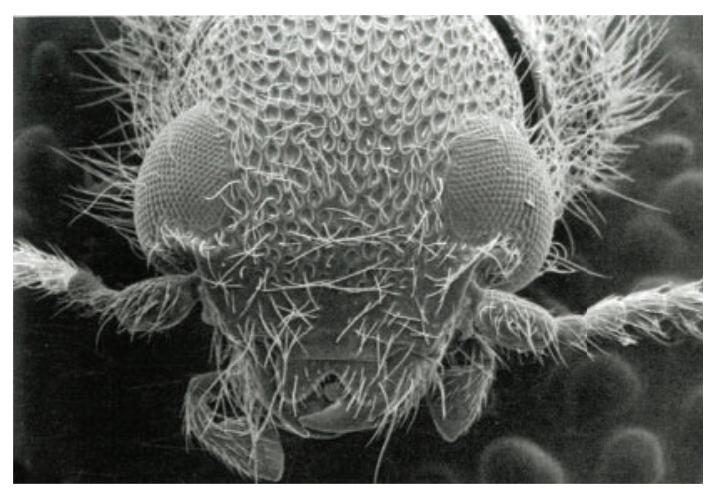

(a)

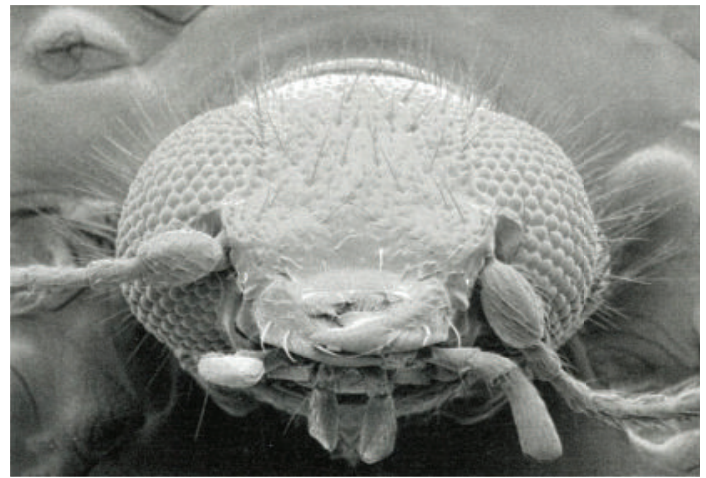

(c)

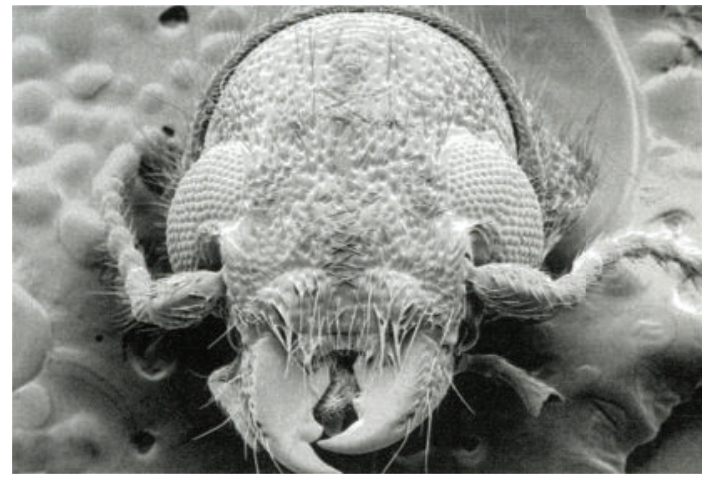

(e)

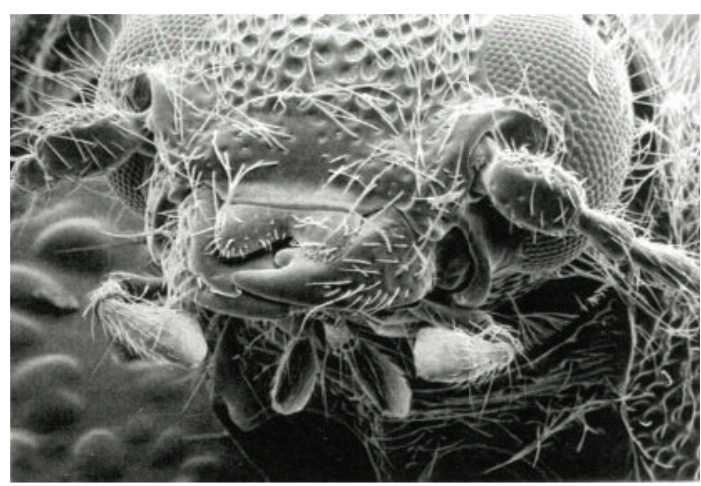

(b)

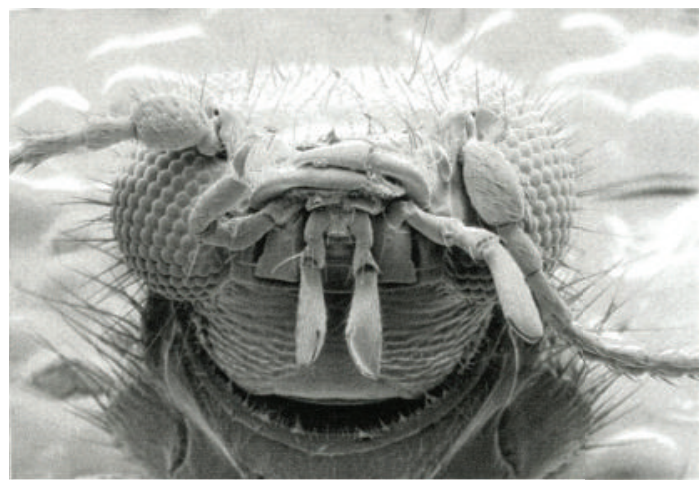

(d)

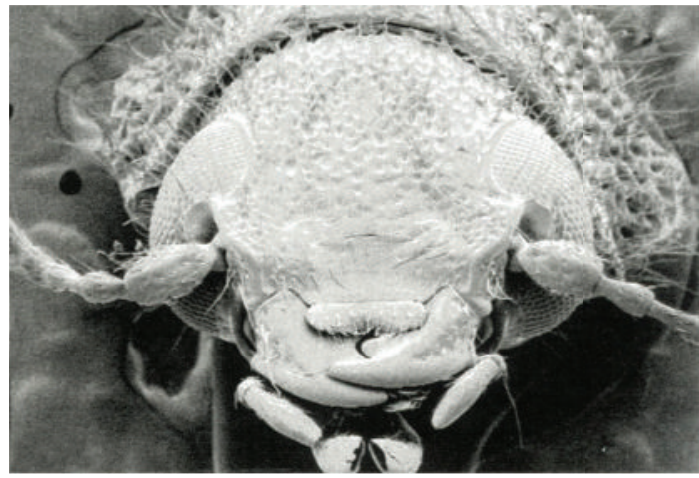

(f)

Figure 12: Various organs. (a, b) Blackburniella intricata ((a) head, (b) mouthparts). (c, d) Fallopylus pallipes ((c) head, (d) mouthparts). (e) Neopylus nahuelbutensis head. (f) Parapylus bicinctus head.

organs (Figure 13(i)): saccular bursa copulatrix present, bursa with two basal sclerites, spermathecal capsule well sclerotized, spermathecal gland very long, attached to base of spermatheca.

Distribution. The members of this genus have been found only in Australia.

Species Examined. Pylus fatuus Newman and one undescribed species.

Notes. Kolibáč [6] provides illustrations of various organs of Pylus fatuus Newman.
4.5.14. Rhophaloclerus Fairmaire (Figures 14(a)-14(g), 16(c), 16(d), and 23(c)). Rhophaloclerus Fairmaire [29, 30]. Type species: Rhophaloclerus coquerelii Fairmaire [29]. By monotypy. Kuwert [31]. Corporaal [5]. Liostylus Fairmaire [29]. New Synonymy.

Synapotypic Characteristics. Tibial spur formula 1-2-2.

Diagnosis. This is the only genus of Tarsosteninae with a tibial formula 1-2-2 and known to occur in Madagascar and the Comoros.

Description. Size: length $3.0-6.0 \mathrm{~mm}$; width $0.7-3.0 \mathrm{~mm}$. Form (Figure 23(c)): oblong rectangulate, most species 


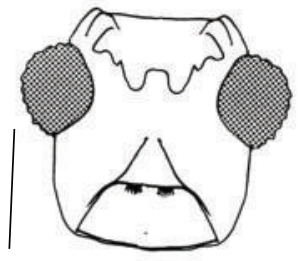

(a)

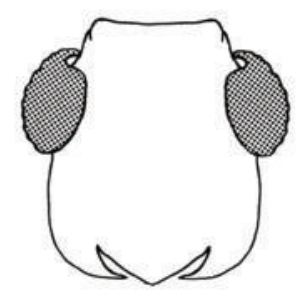

(b)

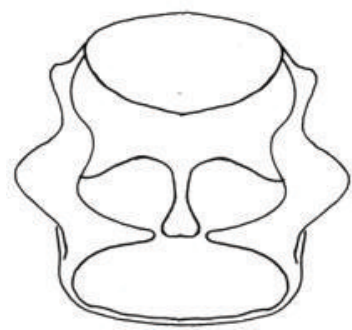

(c)

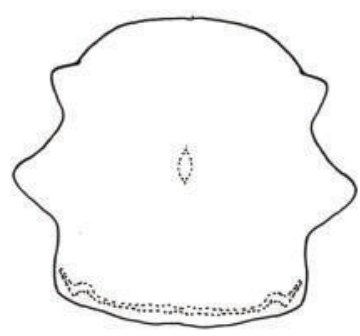

(d)

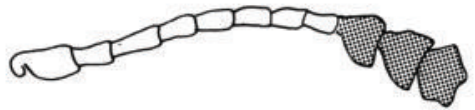

(e)

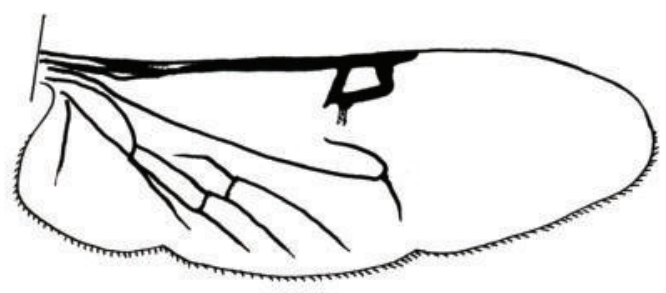

(f)

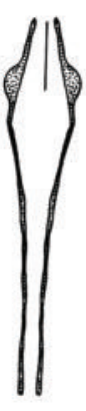

(g)

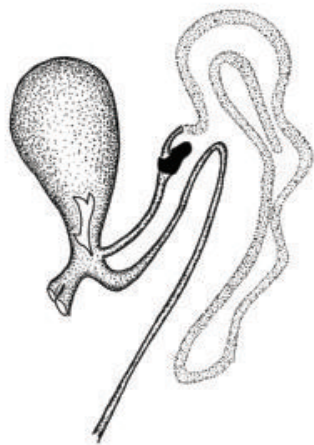

(i)

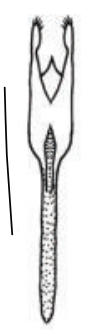

(h)

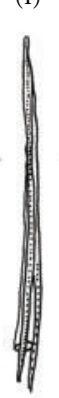

(j)

Figure 13: Various organs of Pylus fatuus. (a, b) Head ((a) ventral, (b) dorsal). (c, d) Pronotum ((c) ventral, (d) dorsal). (e) Antenna. (f) Metathoracic wing. (g) Spiculum. (h) Tegmen. (i) Female mesodermal reproductive organs. (j) Phallus.

narrow, about 3 times longer than broad. Vestiture: disc of cranium and pronotum vested with pale setae, elytral disc vested with $1^{\circ}$ setae and shorter profusely distributed $2^{\circ}$ setae. Head (Figures 14(a), 14(d), and 16(c)): cranium quadrate, frons much wider than width of eye, indented with very small setiferous punctations; gula (Figure 14(a)), large, trapezoidal, sutures oblique, gular processes widely separated, processes in form of two setiferous tubercles; labrum short, deeply incised, transverse tormal processes not confluent, epipharyngeal plate very small; mandible, body short, anterior and medial dens well developed, posterior dens not well developed, penicillus well developed; maxilla, laterolacinia present, terminal palpomere securiform; labium, ligula not incised, terminal palpomere securiform; eyes large, finely facetted, ocular notch large; antenna (Figure 16(d)), capitate, capitulum usually lax, rarely compact, scape about as long as combined length of pedicel and antennomere 3, funicular antennomeres subfiliform, capitular antennomeres expanded, antennomeres 9 and 10 expanded, antennomere 11 ovoid. Thorax: pronotum (Figures 14(b), and 14(c)), usually elongate, rarely transverse-ovoid, disc indented with small setiferous punctations, lateral margins variously convex, dorsolateral ridge extends from posterior angle to anterior angle, not fractured and with smooth surface, sclerotized region above pronotal projection glabrous, prebasal fissure shallow, prointercoxal process not expanded distally; pronotal projections short; elytron sculptured with shallow asetiferous punctations, punctations seriate and diminish in size to elytral apex, $1^{\circ}$ setae always adjacent to asetiferous punctations, $2^{\circ}$ setae densely distributed, epipleural 


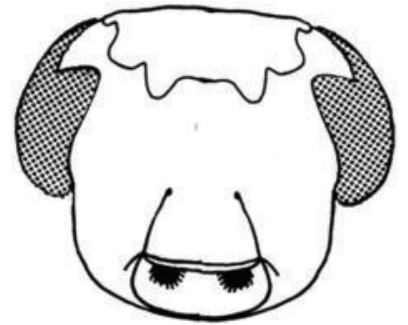

(a)

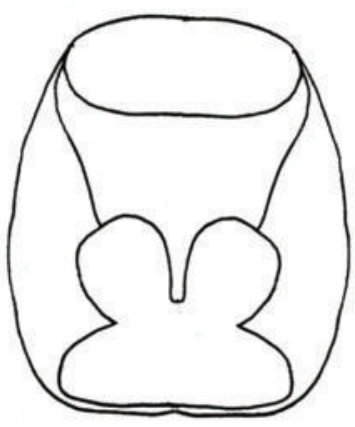

(b)

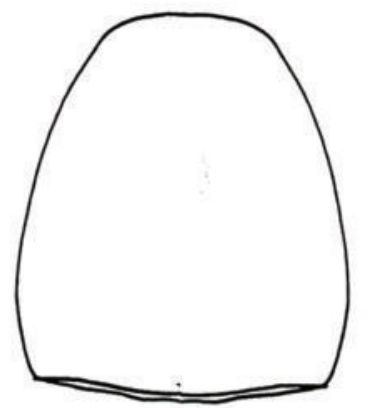

(c)

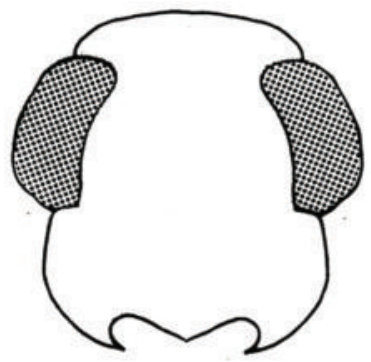

(d)

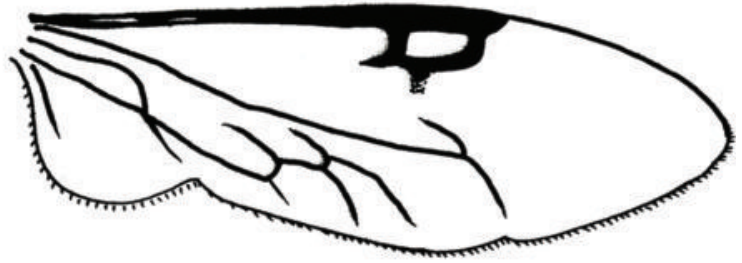

(e)

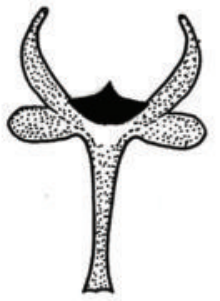

(f)

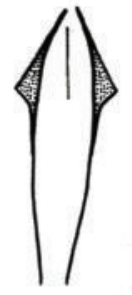

(g) Metathoracic wing. (f) Metendosternite. (g) Spiculum.

fold laterally positioned, narrowed to elytral apex, anterior margin carinate; metathoracic wing (Figure 14(e)), wedge cell open; metendosternite (Figure 14(f)), with furcal lamina, furcal anterior plate prominent; legs, tibial spur formula 12-2, tarsal pulvillar formula 3-3-3, unguis without denticle. Abdomen: aedeagus shorter than length of abdomen, phallobase not reduced, lobate and narrowed distally, lobes fimbriate; phallic lateral plates narrow, phallobasic rod linear or transverse, furcated distally or not furcated, phallic apex minute, spicular plates very narrow (Figure $14(\mathrm{~g})$ ), spicular apodemes not fused at extremity, intraspicular plate rod shaped; ovipositor, ventral and dorsal laminae unilobed, laminal rod present; distal margin of pygidium not incised, distal margin of male 6th sternite slightly incised. Alimentary canal: not studied. Male mesodermal internal reproductive organs: not studied. Female mesodermal internal reproductive organs: spermathecal capsule subovoid, well sclerotized, spermathecal gland attached to middle of spermathecal capsule.

Distribution. Known only from Madagascar and Comoros.

Species Examined. Rhophaloclerus coquerelii Fairmaire, $R$. pictus (Fairmaire) (new combination), R. vadoni Pic, and five species that may or may not be described. 


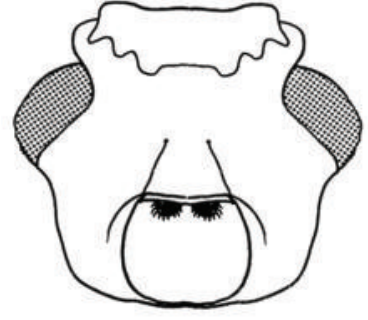

(a)

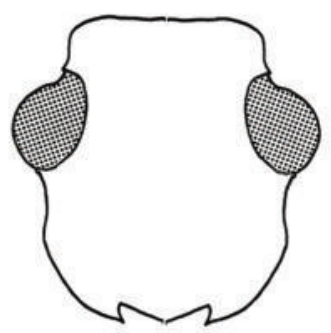

(b)

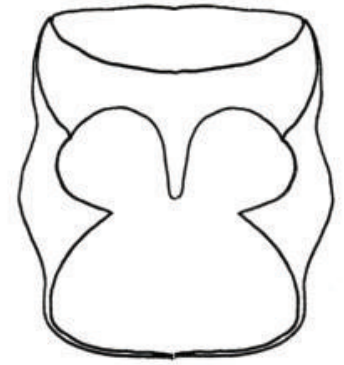

(c)

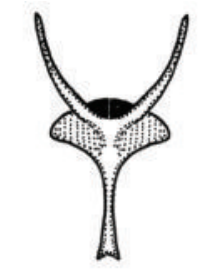

(d)
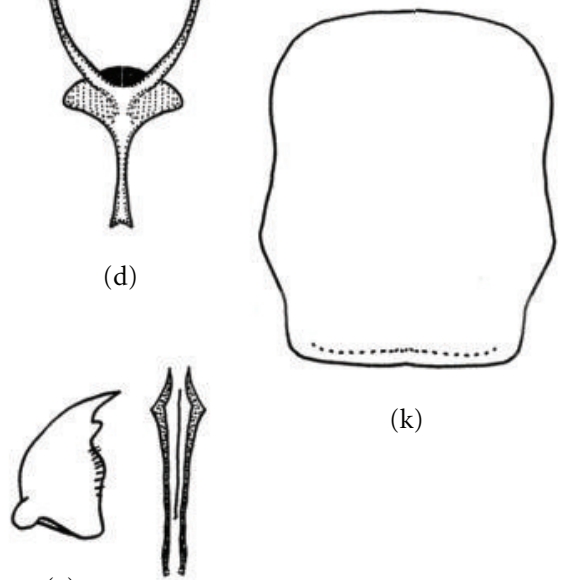

(k)

(e)

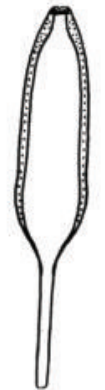

(l)

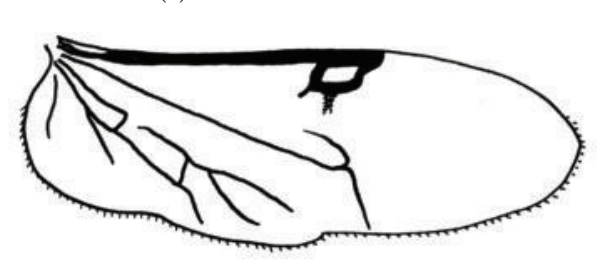

(g)

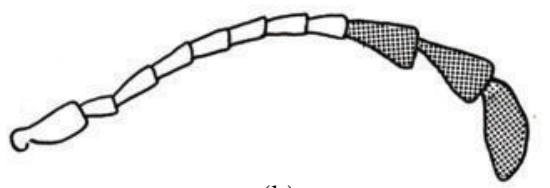

(h)

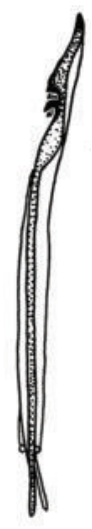

$(\mathrm{m})$

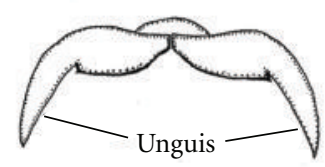

(i)

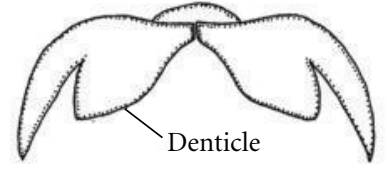

(j)

Figure 15: Various organs. (a)-(h), and (k)-(m) Riotenerus fossipenne. (a, b) Head ((a) ventral, (b) dorsal). (c) Pronotum (ventral), (d) Metendosternite. (e) Mandible. (f) Spiculum. (g) Metathoracic wing. (h) Antenna. (i) and (j) Generalized unguis ((i) without denticle, (j) with denticle). (k) Pronotum (dorsal). (l) Tegmen. (m) Phallus.

Notes. By placing the description of Rhophaloclerus Fairmaire amidst descriptions of other Tillinae genera Fairmaire $[29,32]$ gave the impression to subsequent authors $[5,33]$ that the genus in question belongs in Tillinae. The reduced 4th tarsomere and the characteristics of the antenna clearly indicate that Rhophaloclerus Fairmaire is appropriately classified in Tarsosteninae.

4.5.15. Riotenerus Pic (Figures 15(a)-15(h), 15(k)-15(m), 16(e), 16(f), 21(e), and 23(d)). Riotenerus Pic [34]. Type species: Pelonium fossipenne Schenkling [21]. By monotypy. Solevicens [35]. Opitz [1].
Synapotypic Characteristics. Elytral disc devoid of $2^{\circ}$ setae; aedeagus with uncinate projections; interspicular plate very long (Figure 15(f)).

Diagnosis. Distinguishable from the superficially similar specimens of Abiliella Peracchi by the lack of elytral $2^{\circ}$ setae.

Description. Size: length $5.0-8.5 \mathrm{~mm}$; width $2.0-2.5 \mathrm{~mm}$. Form (Figure 23(d)): oblong rectangulate, about 3 times longer than broad. Vestiture: disc of cranium and pronotum vested with white setae, elytral disc vested with $1^{\circ}$ setae, $2^{\circ}$ setae absent. Head (Figures 15(a), 15(b), and 16(e)): 


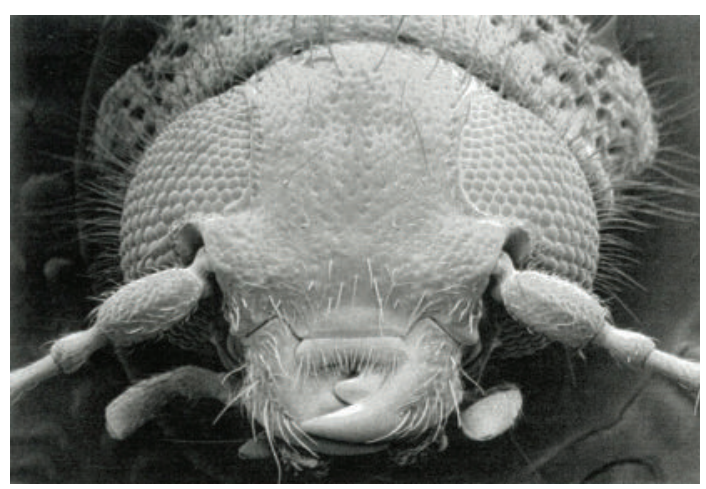

(a)

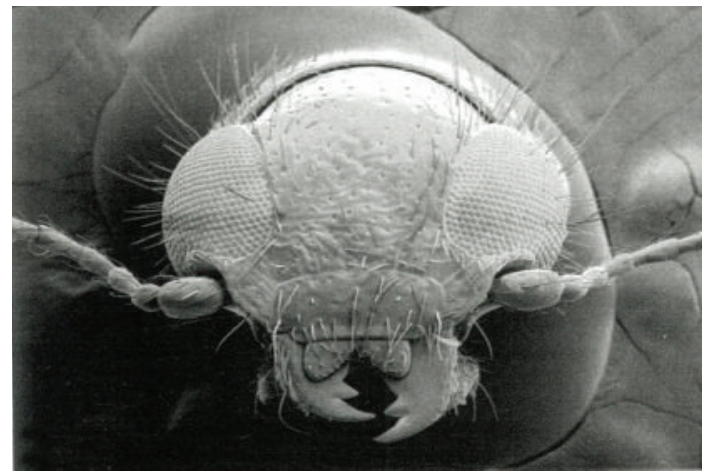

(c)

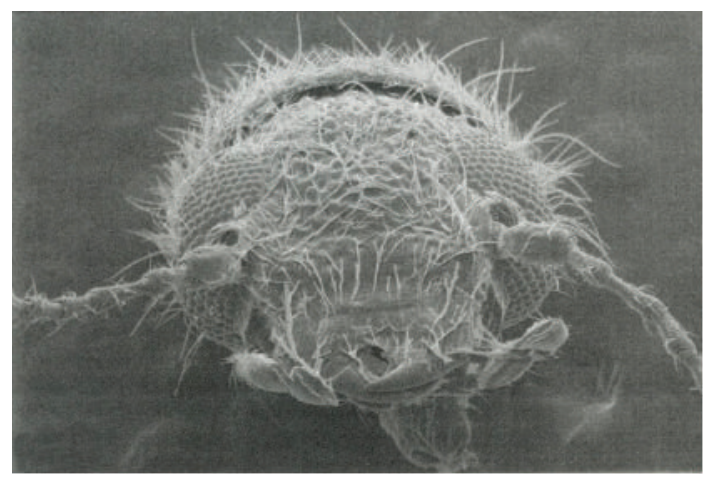

(e)

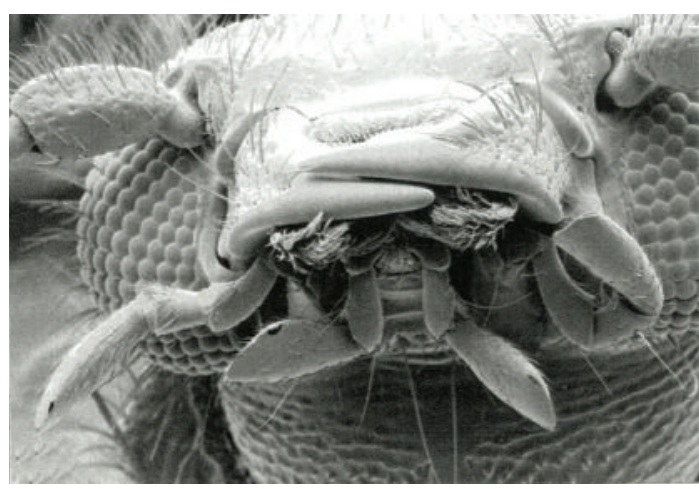

(b)

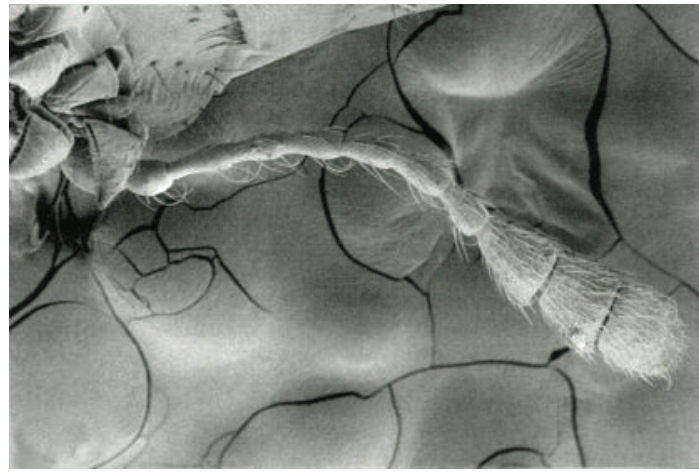

(d)

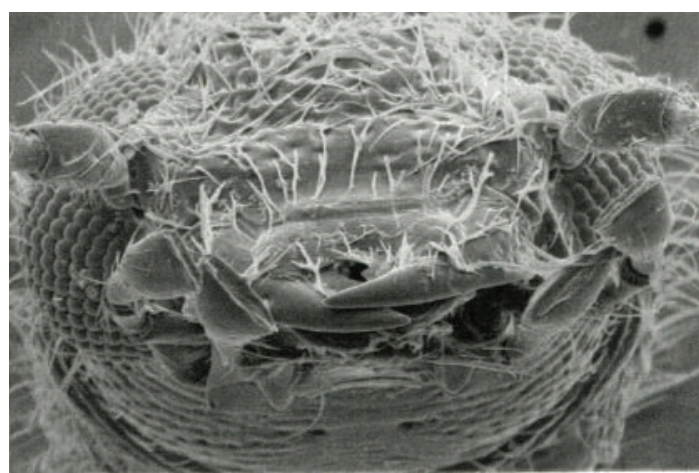

(f)

Figure 16: Various organs. (a, b) Pylus fatuus ((a) head, (b) mouthparts). (c, d) Rhophaloclerus coquerelli ((c) head, (d) antenna). (e, f) Riotenerus fossipenneus ((e) head, (f) mouthparts).

cranium quadrate, frons wider than width of eye, indented at middle and with large setiferous punctations that give cranium rugose appearance; gula (Figure 15(a)), large, trapezoidal, sutures oblique, gular processes widely separated, processes in form of two setiferous tubercles; labrum short, medial incision shallow, transverse tormal processes sinuous, confluent, epipharyngeal plate very small; mandible (Figure 15(e)), body stout, anterior, medial, and posterior dens well developed, penicillus well developed; maxilla (Figure 16(f)), laterolacinia present, terminal palpomere securiform; labium (Figure 16(f)), ligula not deeply incised, terminal palpomere securiform; eyes small, coarsely faceted, ocular notch small; antenna (Figures 15(h) and 21(e)), capitate, capitulum lax and narrow, scape about as long as combined length of pedicel and antennomere 3, funicular antennomeres filiform, capitular antennomeres narrow, antennomeres 9 and 10 subrectangular, antennomere 11 ovoid. Thorax: pronotum (Figures 15(c), and 15(k)), elongate, convex, side margins sinuous, sculptured with large round setiferous punctations, dorsolateral ridge extends from posterior angle to pronotal midline, surface coarsely punctated, prebasal fissure well developed, prointercoxal process not expanded distally; pronotal projections short; elytron sculptured with large spheroid asetiferous punctations, latter sub seriate, $1^{\circ}$ setae always adjacent to asetiferous punctations, $2^{\circ}$ setae absent, epipleural fold 


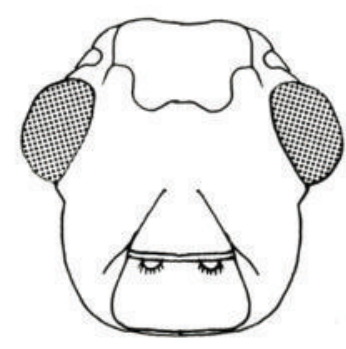

(a)

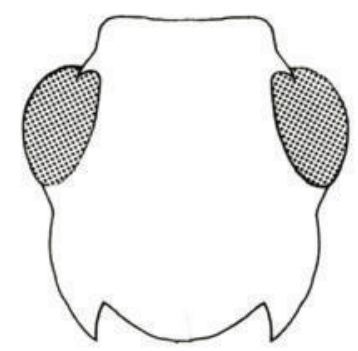

(b)

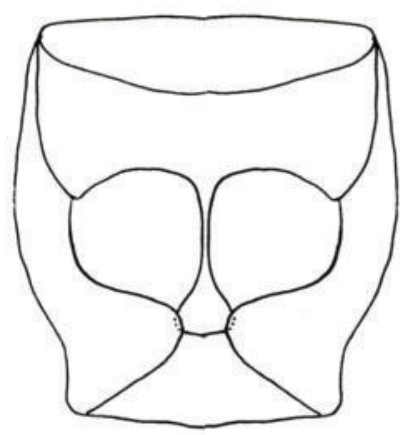

(c)

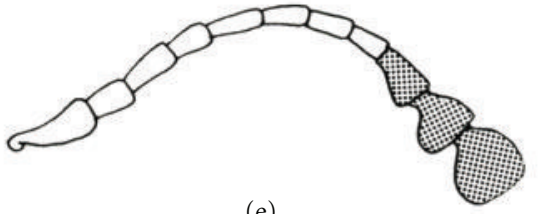

(e)

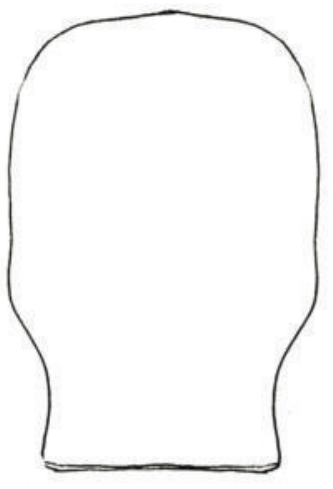

(d)

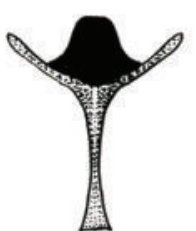

(f)

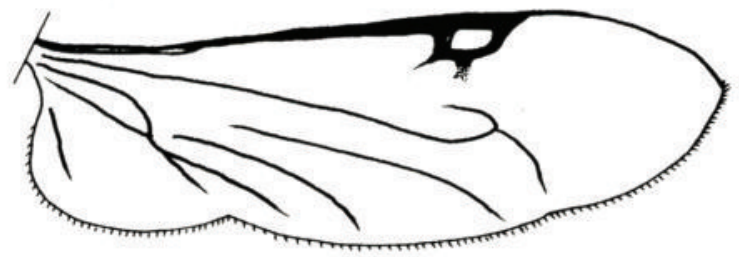

(g)

Figure 17: Various organs of Tarsostenodes simulator. (a, b) Head ((a) ventral, (b) dorsal). (c, d) Pronotum ((c) ventral, (d) dorsal). (e) Antenna. (f) Metendosternite. (g) Metathoracic wing. (h) Spiculum. (i) Tegmen. (j) Phallus.

laterally positioned, extended to elytral apex, anterior margin carinate; metathoracic wing (Figure 15(g)), wedge cell open; metendosternite (Figure 15(d)), with furcal lamina, furcal anterior plate diminutive, acuminate; legs, tibial spur formula 0-1-1, tarsal pulvillar formula 3-3-3, unguis without denticle. Abdomen: aedeagus (Figures 15(1), and 15(m)), shorter than length of abdomen, phallobase not lobate distally; phallic lateral plates very broad and uncinate distally; spicular plates small, triangular, acuminate, rarely, spicular apodemes not fused (Figure 15(f)), intraspicular plate rod shaped and very long; ovipositor, ventral and dorsal laminae unilobed, laminal rod present; distal margin of pygidium not incised, distal margin of male 6th sternite slightly incised. Alimentary canal: not studied. Male mesodermal internal reproductive organs: not studied. Female mesodermal internal reproductive organs: not studied.

Distribution. The members of this genus have been found only in Argentina.

Species Examined. Riotenerus fossipenne (Schenkling).

4.5.16. Tarsostenodes Blackburn (Figures 17(a)-17(j), 20(a), 20(b), and 23(f)). Tarsostenodes Blackburn [36]. Type species: Tarsostenodes simulator Blackburn [36]. By monotypy. Corporaal [5]. Kolibáč [6]. Bartlett [37]. 


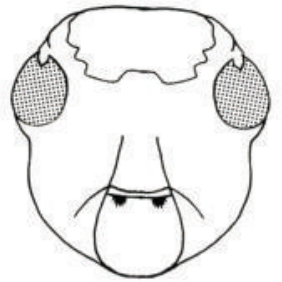

(a)

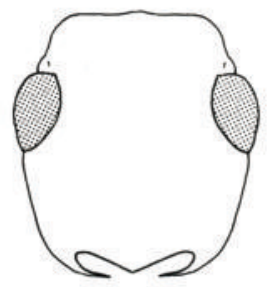

(b)

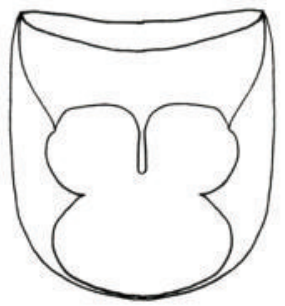

(c)

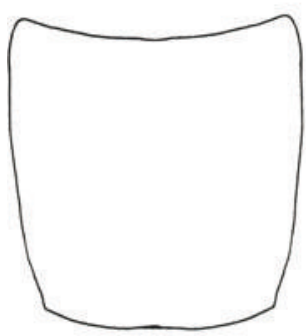

(d)

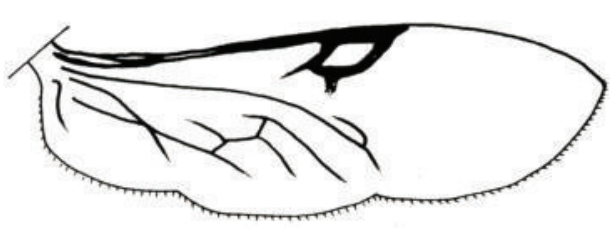

(e)

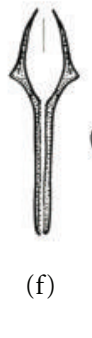

(i)

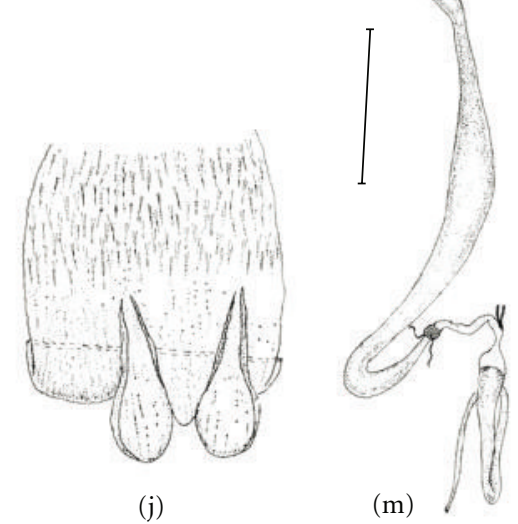

(g)

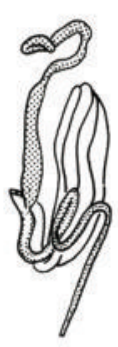

(k)

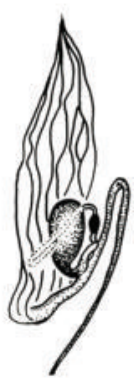

(1)

(h)

Figure 18: Various organs of Tarsostenus univittatus. (a, b) Head ((a) ventral, (b) dorsal). (c, d) Pronotum ((c) ventral, (d) dorsal). (e) Metathoracic wing. (f) Spiculum. (g) Aedeagus. (h) Metendosternite. (i) Antenna. (j) Stomodaeal valve (interior view). (k) Male mesodermal reproductive organs. (l) Female mesodermal reproductive organs. (m) Alimentary canal.

Synapotypic Characteristics. Procoxal cavity closed externally, pronotal projections wide, metathoracic wing cross veins rudimentary or missing, furcal lamina absent, epipleural fold narrow, elytra constricted at middle, phallobasic rod absent.

Diagnosis. The closure of the external aspects of the procoxal cavities (Figure 17(c)) will separate the members of this genus from any other within Tarsosteninae.

Description. Size: length $4.0-8.0 \mathrm{~mm}$; width $1.0-2.0 \mathrm{~mm}$. Form (Figure 23(f)): oblong, narrow rectangulate, about 4 times longer than broad. Vestiture: disc of cranium and pronotum densely vested with pale setae, elytral disc vested with $1^{\circ}$ setae and shorter profusely distributed $2^{\circ}$ setae. Head (Figures 17(a), 17(b), and 20(a)): cranium quadrate, frons much wider than width of eye, indented with large setiferous punctations; gula (Figure 17(a)), large, trapezoidal, sutures oblique, gular processes widely separated, processes in form of two setiferous tubercles; labrum short, deeply incised, transverse tormal processes not confluent, epipharyngeal plate very small; mandible, body long, anterior and medial dens well developed, posterior dens not well developed, penicillus well developed; maxilla (Figure 20(b)), laterolacinia present, terminal palpomere securiform; labium, ligula 


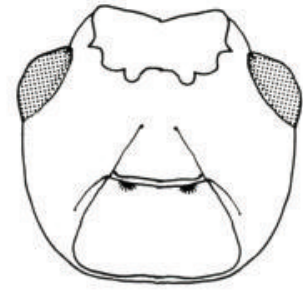

(a)

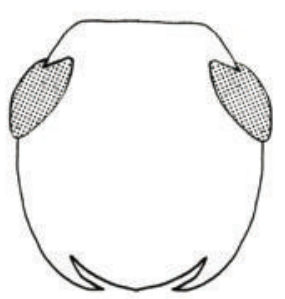

(b)

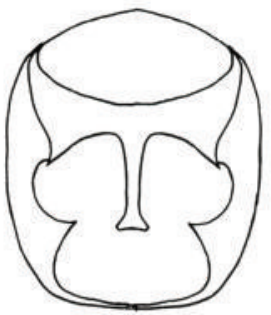

(c)

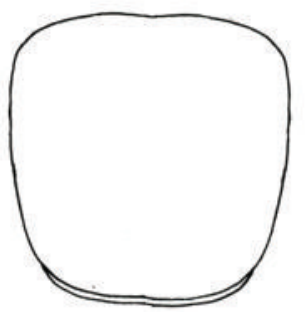

(d)

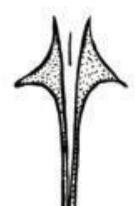

(e)

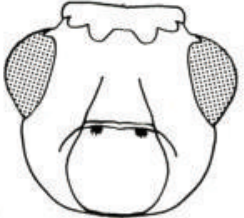

(g)

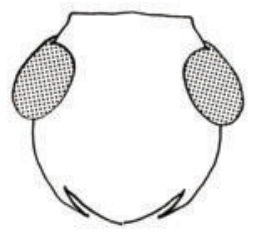

(h)

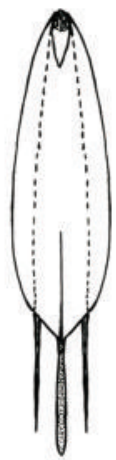

(f)

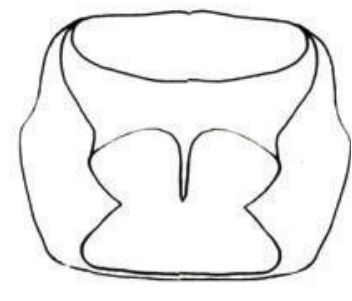

(i)

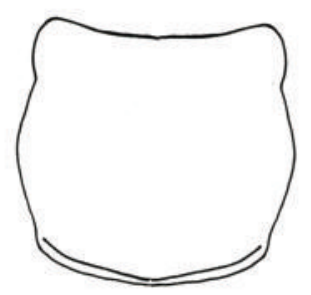

(j)

FIgURe 19: Various organs. (a)-(f) Thriocera pectoralis. (a, b) Head ((a) ventral, (b) dorsal). (c, d) Pronotum ((c) ventral, (d) dorsal). (e) Spiculum. (f) Aedeagus. (g)-(j) Thriocerodes bifasciatus. (g, h) Head ((g) ventral, (h) dorsal). (i) and (j) Pronotum ((i) ventral, (j) dorsal).

deeply incised, terminal palpomere securiform; eyes large, coarsely faceted, ocular notch large; antenna (Figure 17(e)), capitate, capitulum usually compact, rarely lax, scape about as long as combined length of pedicel and antennomere 3 , funicular antennomeres filiform, capitular antennomeres expanded, antennomeres 9 and 10 expanded, antennomere 11 ovoid. Thorax: pronotum (Figures 17(c), and 17(d)), elongate, usually campaniform, rarely suboval, usually deeply constricted at base, disc indented with large setiferous punctations, interstitial spaces (spaces between punctations), very elevated, dorsolateral ridge extends from posterior angle to anterior midpoint, fractured by coarse punctations, sclerotized region above pronotal projection glabrous, prebasal fissure shallow, prointercoxal process very expanded distally, process confluent with pronotal projections (Figure 17(c)), latter particularly wide; elytron sculptured with deep asetiferous punctations, punctations seriate, rarely diminish in size to elytral apex, $1^{\circ}$ setae always adjacent to asetiferous punctations, $2^{\circ}$ setae densely distributed, interstitial spaces elevated, epipleural fold laterally positioned, very narrow to elytral apex, anterior margin not carinate; metathoracic wing (Figure $17(\mathrm{~g})$ ), cross veins rudimentary or missing; metendosternite (Figure 17(f)), without furcal lamina, furcal anterior plate prominent; legs, tibial spur formula 1-21, tarsal pulvillar formula 3-3-3, unguis without denticle. Abdomen: aedeagus (Figures 17(i), and 17(j)), shorter 


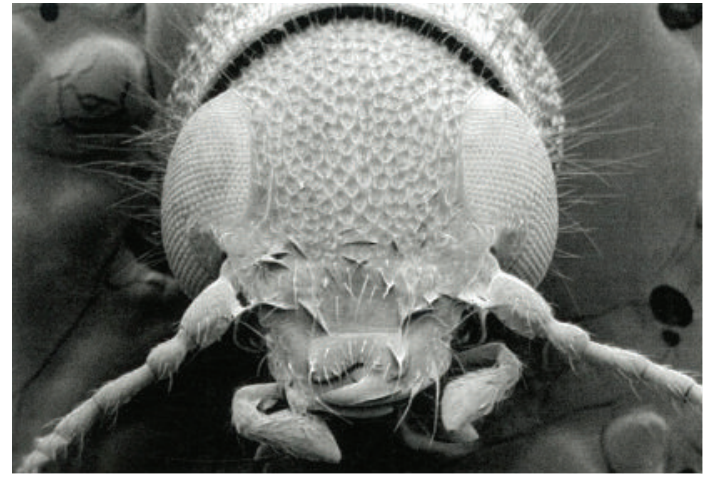

(a)

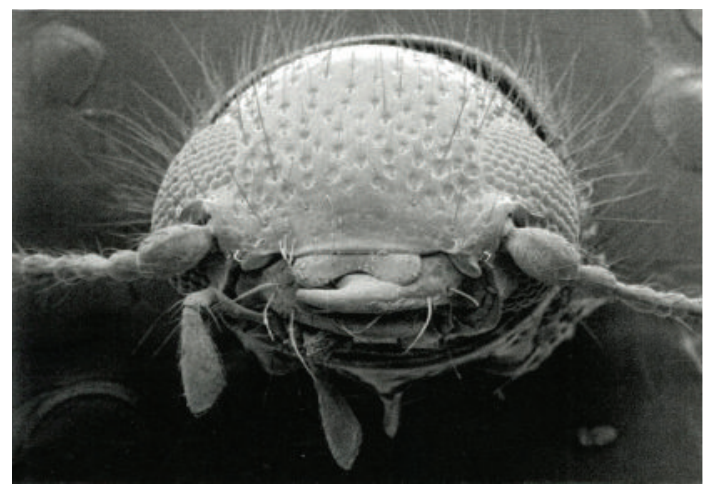

(c)

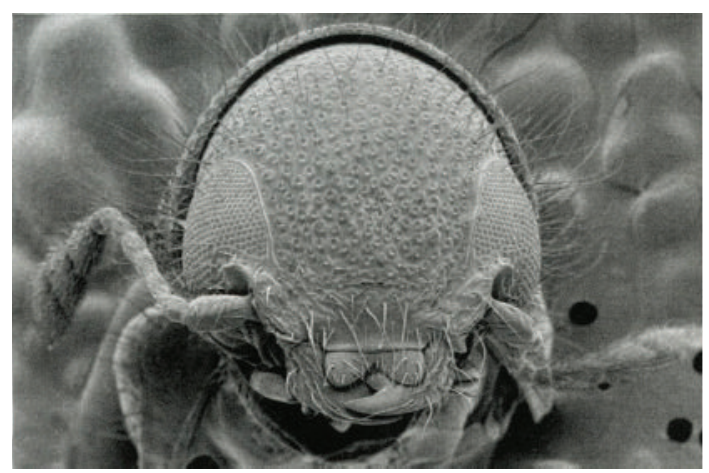

(e)

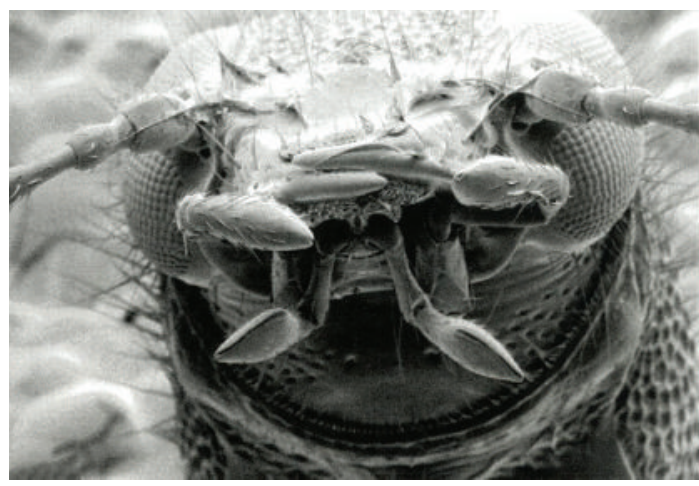

(b)

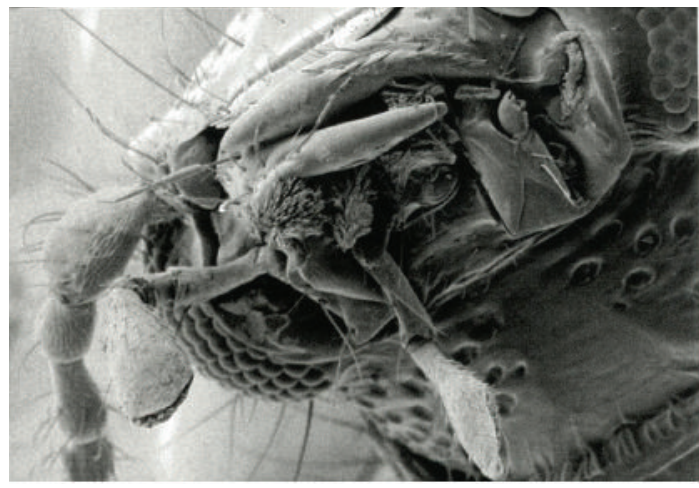

(d)

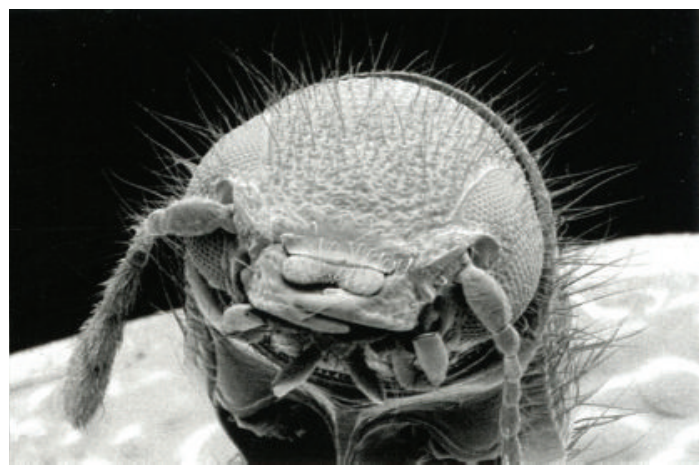

(f)

FIgURE 20: Various organs. (a, b) Tarsostenodes simulator ((a) head, (b) mouthparts). (c, d) Tarsostenus univittatus ((c) head, (d) mouthparts). (d, e) Thriocera pectoralis ((d) head, (e) mouthparts).

than length of abdomen, phallobase not reduced, lobate, lobes fimbriate; phallic lateral plates wide, phallobasic rod absent, phallic apex robust, spicular plates very narrow (Figure 17(h)), spicular apodemes fused, intraspicular plate rod shaped; ovipositor, ventral and dorsal laminae unilobed, laminal rod present; distal margin of pygidium not incised, distal margin of male 6th sternite slightly incised. Alimentary canal: not studied. Male mesodermal internal reproductive organs: not studied. Female mesodermal internal reproductive organs: spermathecal capsule tubular, well sclerotized, spermathecal gland attached to middle of spermathecal capsule.

Distribution. Known only from continental Australia and Lord Howe Island.
Species Examined. Tarsostenodes albonotatus Pic, T. cribripennis Schenkling, T. guttulus (White), T. howensis Bartlett, T. leucogramma Elston, T. simulator Blackburn, and four undescribed species.

4.5.17. Tarsostenosis Heller (Figure 23(e)). Tarsostenosis Heller [38]. Type species: Tarsostenosis tricolor Heller [38]. By monotypy. Corporaal [5].

Synapotypic Characteristics. Pronotum with linear glabrous elevations.

Diagnosis. Specimens belong to this genus if their pronotum shows a poorly developed lateral tubercle, the pronotum has 


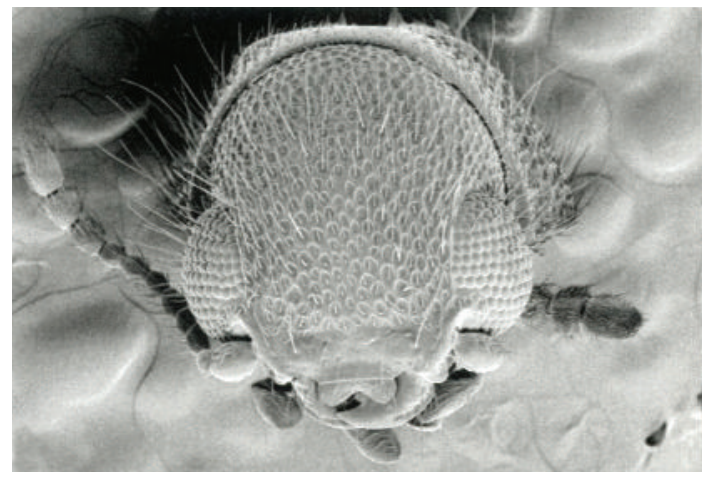

(a)

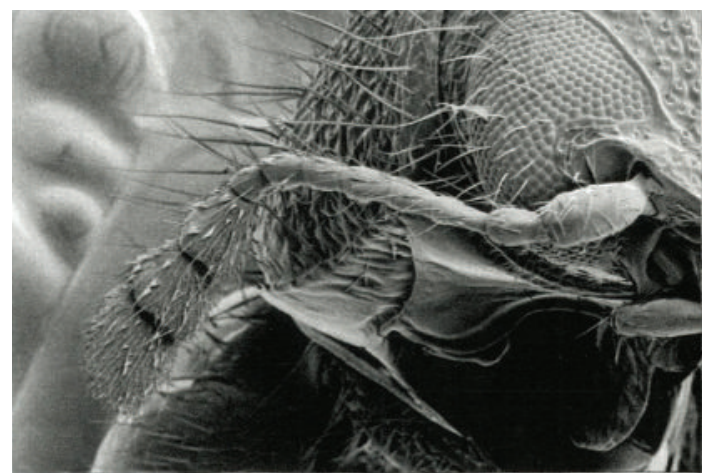

(c)

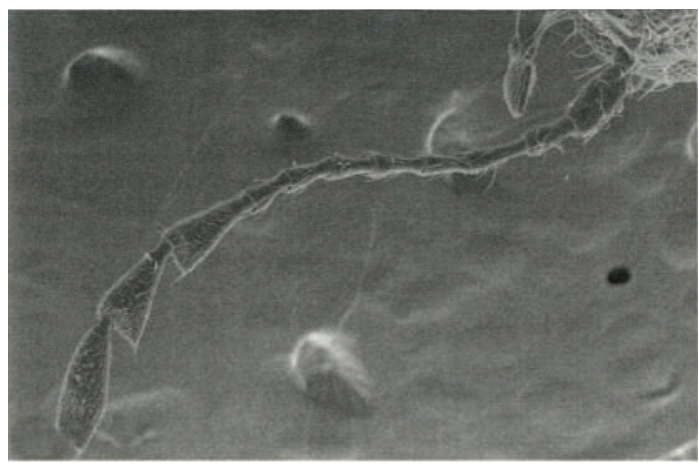

(e)

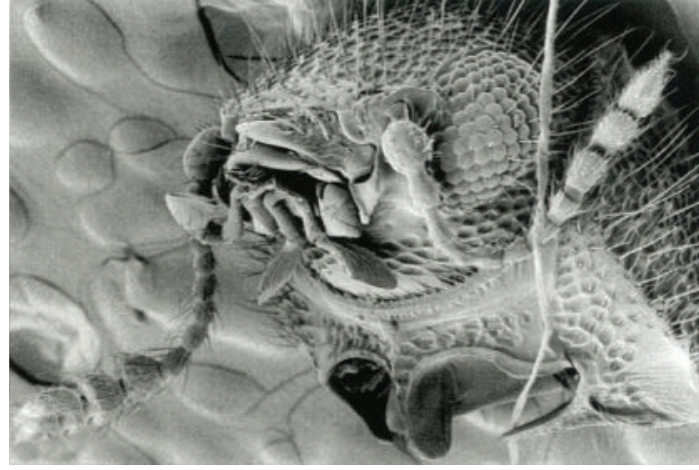

(b)

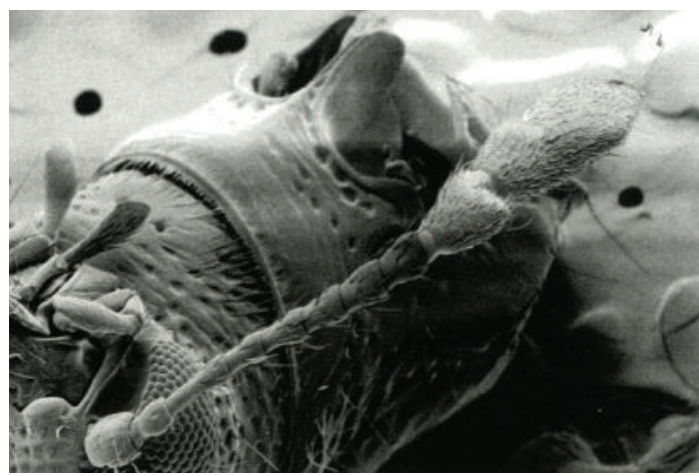

(d)

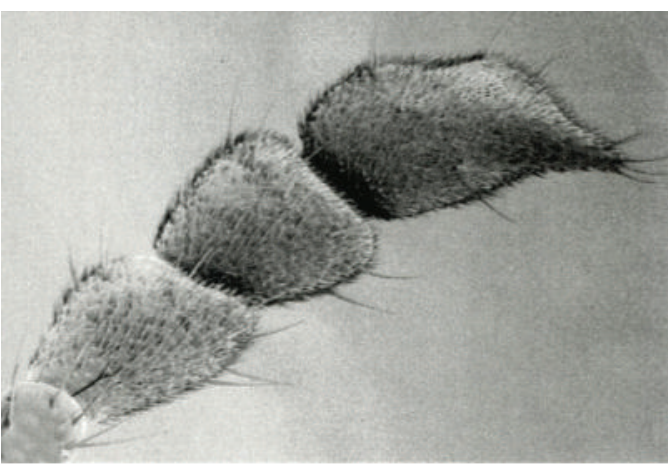

(f)

Figure 21: Various organs. (a, b) Thriocerodes bifasciatus ((a) head, (b) mouthparts). (c) Thriocera pectoralis antenna. (d) Tarsostenus univttatus antenna. (e) Riotenerus fossipenneus antenna. (f) Fallopylus pallipes capitulum.

shallow linear glabrous elevations, and the elytra are devoid of $2^{\circ}$ setae.

Description. Size: length $3.5-5.0 \mathrm{~mm}$; width $1.0-1.5 \mathrm{~mm}$. Form (Figure 23(e)): oblong, narrow rectangulate, about 4 times longer than broad. Vestiture: disc of cranium and sides of pronotum densely vested with pale setae, pronotal middle sparsely setose, elytral disc vested with $1^{\circ}$ setae, $2^{\circ}$ setae absent. Head: cranium quadrate, frons much wider than width of eye, indented with large setiferous punctations; gula large, trapezoidal, sutures oblique, gular processes widely separated, processes in form of two setiferous tubercles; labrum short, deeply incised, transverse tormal processes confluent, epipharyngeal plate very small; mandible, body short, anterior and medial dens well developed, posterior dens not well developed, penicillus well developed; maxilla, laterolacinia present, terminal palpomere securiform; labium, ligula deeply incised, terminal palpomere securiform; eyes small, coarsely faceted, ocular notch small; antenna, capitate, capitulum lax, scape about as long as combined length of pedicel and antennomere 3, funicular antennomeres filiform, capitular antennomeres slightly expanded, antennomeres 9 and 10 subtriangular, antennomere 11 ovoid. Thorax: pronotum quadrate, disc at sides indented with large setiferous punctations, disc at middle sparsely punctate, with linear glabrous elevations, dorsolateral ridge extends from posterior angle to anterior midpoint, fractured by coarse punctations, sclerotized region above pronotal projection not glabrous, prebasal fissure shallow, prointercoxal process not expanded distally, pronotal projections 


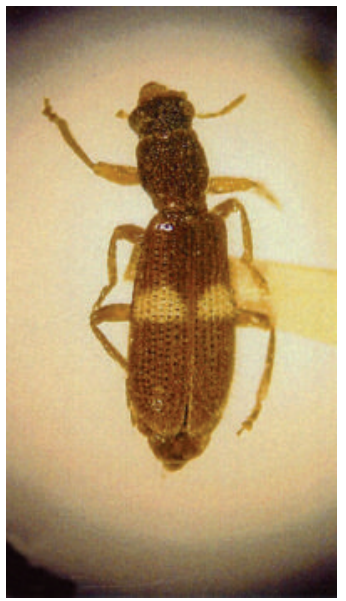

(a)

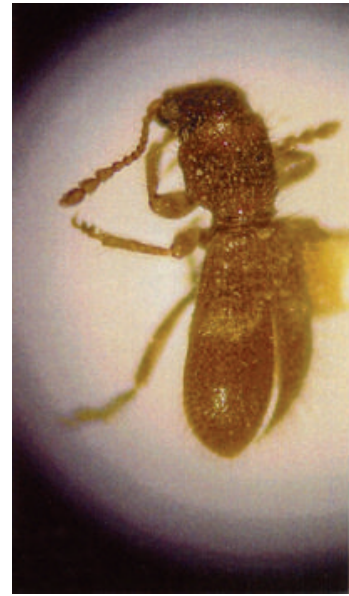

(d)

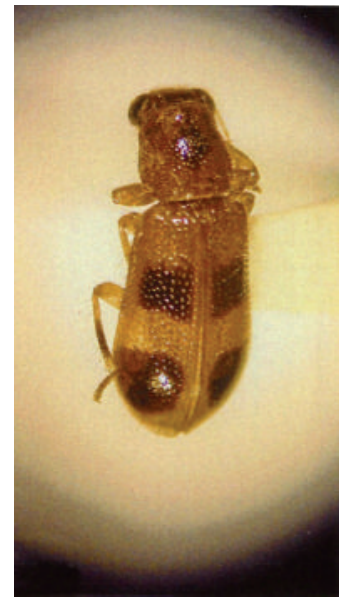

(g)

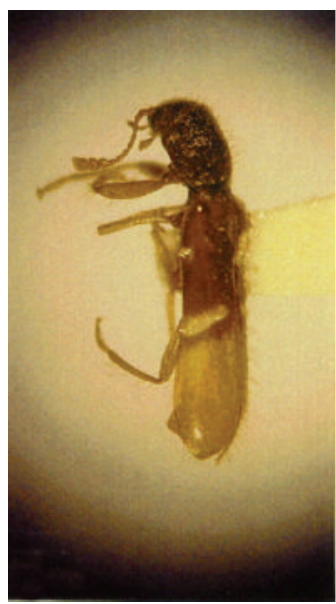

(b)

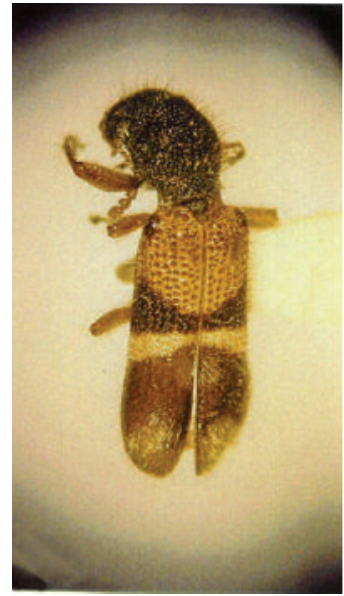

(e)

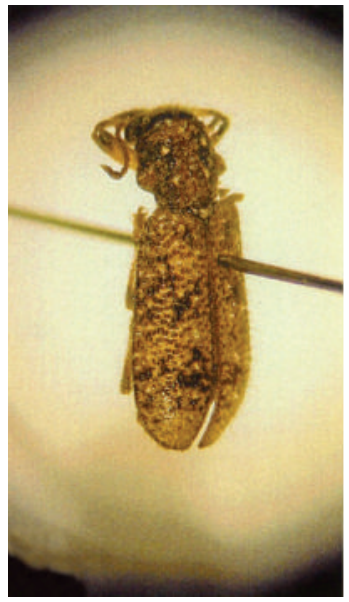

(h)

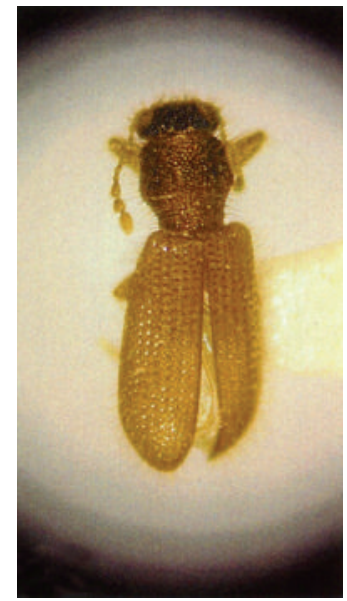

(c)

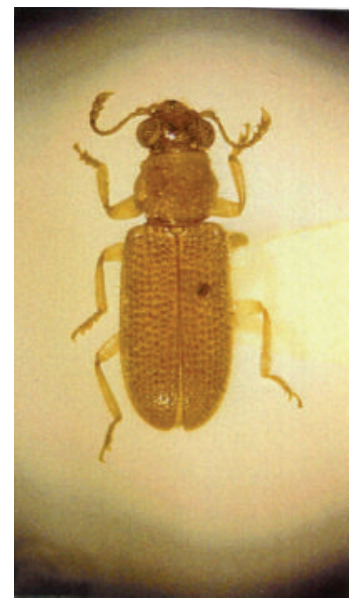

(f)

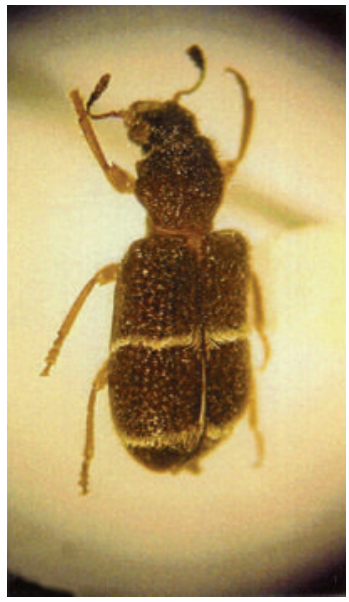

(i)

Figure 22: Habitus. (a) Abiliella fasciata. (b) Agapetilus vietus. (c) Apopylus unumgarensis. (d) Apteropilo pictipes. (e) Blackburniella intricata. (f) Fallopylus pallipes. (g) Globoclava quadrimaculata. (h) Neopylus nahuelbutensis. (i) Parapylus bicinctus. 


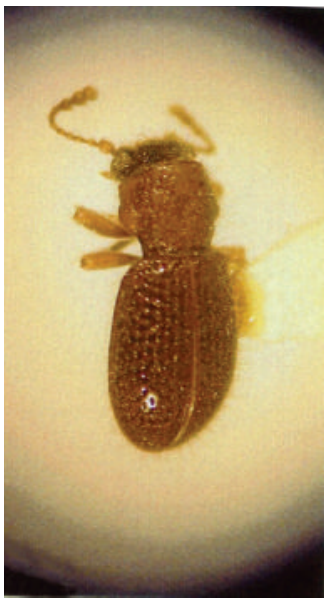

(a)

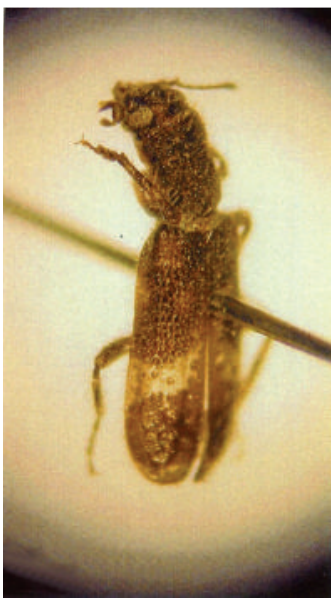

(d)

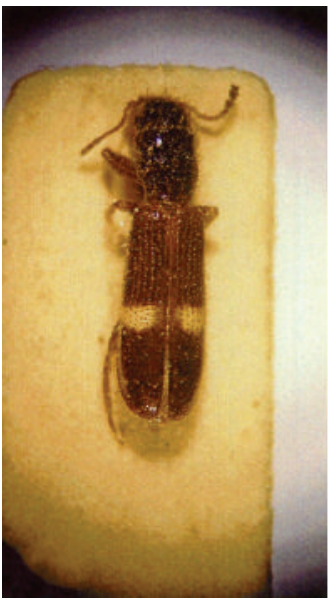

(g)

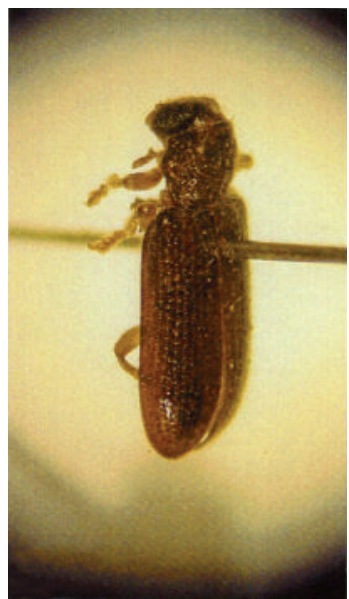

(b)

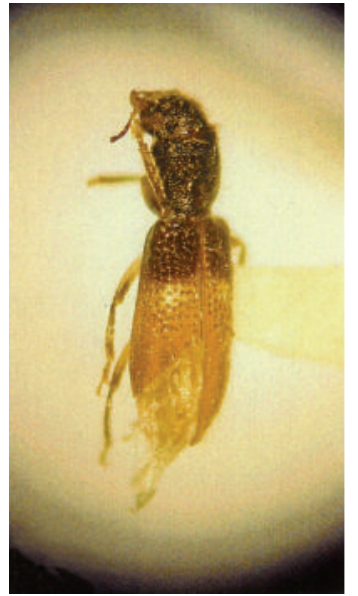

(e)

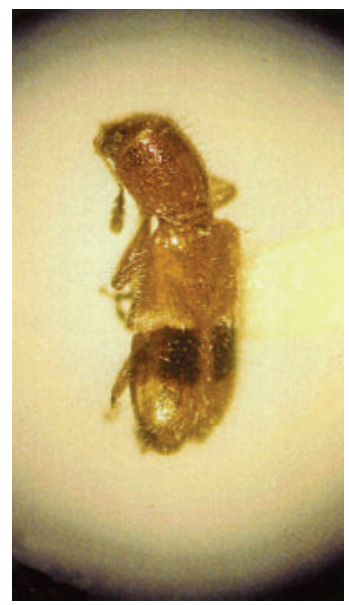

(h)

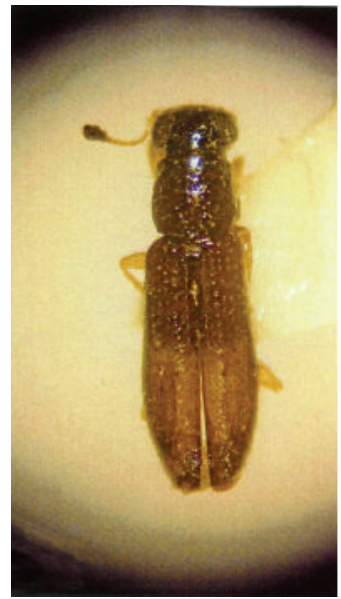

(c)

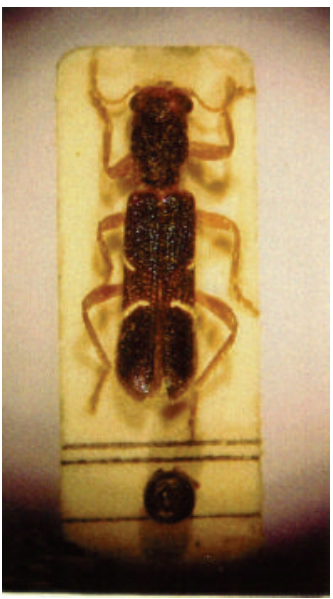

(f)

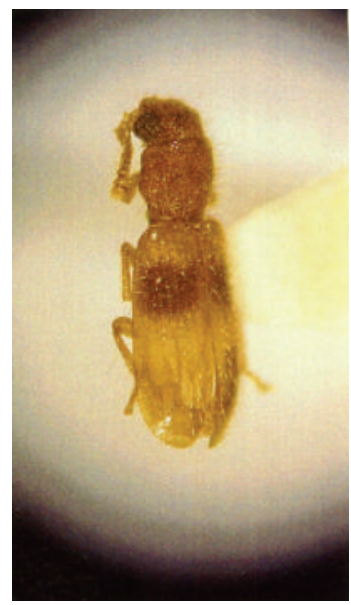

(i)

Figure 23: Habitus. (a) Pseudopylus okei. (b) Pylus fatuus. (c) Rhophaloclerus coquerelii. (d) Riotenerus fossipennes. (e) Tarsostenosis tricolor. (f) Tarsostenodes simulator. (g) Tarsostenus univttatus. (h) Thriocera pectoralis. (i) Thriocerodes bifasciatus. 


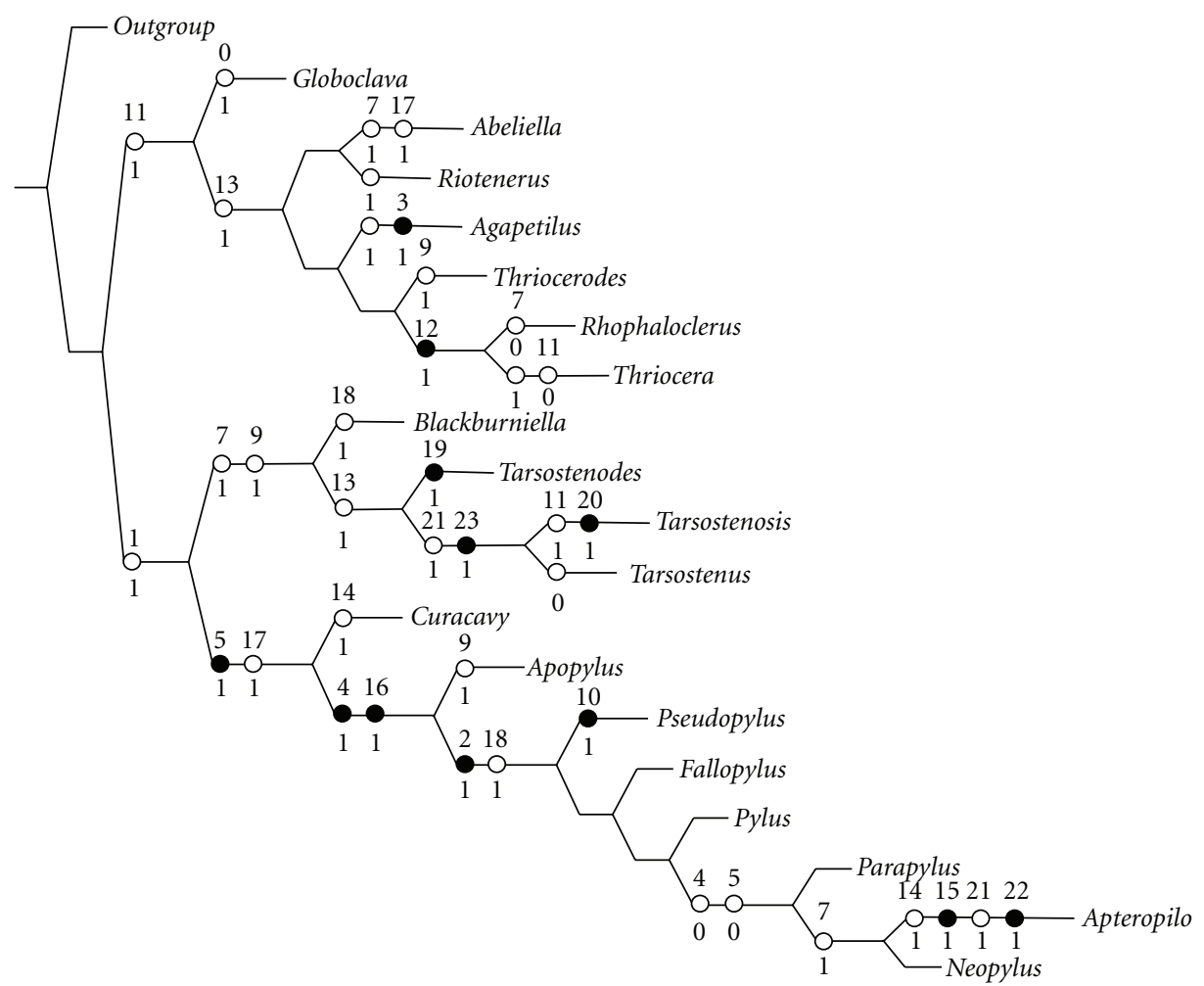

Figure 24: Phylogeny of genera of Tarsosteninae.

short; elytron sculptured with round asetiferous punctations, punctations seriate and extend to elytral distal two-thirds, $1^{\circ}$ setae always adjacent to asetiferous punctations, $2^{\circ}$ setae absent, interstitial spaces smooth, epipleural fold laterally positioned, very narrow to elytral apex, anterior margin carinate; metathoracic wing with open wedge cell; metendosternite with furcal lamina, furcal anterior plate shallow; legs, tibial spur formula 1-2-1, tarsal pulvillar formula 33-3, unguis without denticle. Abdomen: aedeagus shorter than length of abdomen, phallobase not reduced, not lobate but fimbriate; phallic lateral plates narrow, phallobasic rod linear, phallic apex robust, spicular plates narrow, slightly acuminate, spicular apodemes not fused, intraspicular plate rod shaped; ovipositor not examined. Alimentary canal: not studied. Male mesodermal internal reproductive organs: not studies. Female mesodermal internal reproductive organs: not studied.

Distribution. Species are known from Australia and New Caledonia.

Species Examined. Tarsostenosis hilaris (Westwood), (new combination), T. tricolor (Heller), and one undescribed species.

4.5.18. Tarsostenus Spinola (Figures 18(a)-18(m), 20(c), 20(d), 21(d), and 23(g)). Tarsostenus Spinola [12]. Type species: Clerus univittatus Rossi [39]. By monotypy. Corporaal [5]. Crowson [40]. Ekis and Gupta [41]. Matthews [22]. Opitz [42]. Kolibáč [6].

Synapotypic Characteristics. Aedeagus inverted, one pair of accessory gland.

Diagnosis. Specimens belong to this genus if their pronotum lacks a lateral tubercle, the dorsolateral ridge is present only in pronotal basal half, and the elytra are devoid of $2^{\circ}$ setae.

Description. Size: length $3.5-8.0 \mathrm{~mm}$; width $1.0-2.0 \mathrm{~mm}$. Form (Figure 23(g)): oblong, narrow rectangulate, about 4 times longer than broad. Vestiture: disc of cranium and sides of pronotum densely vested with pale setae, pronotal middle sparsely setose, elytral disc vested with $1^{\circ}$ setae, $2^{\circ}$ setae absent. Head (Figures 18(a), 18(b), and 20(c)): cranium quadrate, frons much wider than width of eye, indented with large setiferous punctations; gula (Figure 18(a)), large, trapezoidal, sutures oblique, gular processes widely separated, processes in form of two setiferous tubercles; labrum short, deeply incised, transverse tormal processes confluent, epipharyngeal plate very small; mandible, body short, anterior and medial dens well developed, posterior dens not well developed, penicillus well developed; maxilla (Figure 20(d)), laterolacinia present, terminal palpomere subsecuriform; labium, ligula deeply incised, terminal palpomere subsecuriform; eyes small, coarsely faceted, ocular notch small; 
antenna (Figure 18(i)), capitate, capitulum lax, scape about as long as combined length of pedicel and antennomere 3 , funicular antennomeres filiform, capitular antennomeres slightly expanded, antennomeres 9 and 10 subtriangular, antennomere 11 ovoid. Thorax: pronotum (Figures 18(c) and $18(\mathrm{~d})$ ), quadrate, disc at sides indented with large setiferous punctations, disc at middle sparsely punctated, dorsolateral ridge extends from posterior angle to anterior midpoint, fractured by coarse punctations, sclerotized region above pronotal projection not glabrous, prebasal fissure shallow, prointercoxal process not expanded distally, pronotal projections short; elytron sculptured with round asetiferous punctations, punctations seriate and extend to elytral distal twothirds, $1^{\circ}$ setae always adjacent to asetiferous punctations, $2^{\circ}$ setae absent, interstitial spaces smooth, epipleural fold laterally positioned, very narrow to elytral apex, anterior margin carinate; metathoracic wing (Figure 18(e)), wedge cell open; metendosternite (Figure 18(g)), with furcal lamina, furcal anterior plate shallow; legs, tibial spur formula 1-2-1, tarsal pulvillar formula 3-3-3, unguis without denticle. Abdomen: aedeagus (Figure $18(\mathrm{~g})$ ), shorter than length of abdomen, phallobase not reduced, lobate, lobes fimbriate; phallic lateral plates narrow, phallobasic rod linear, phallic apex robust, spicular plates narrow, slightly acuminate, spicular apodemes not fused (Figure 18(f)), intraspicular plate rod shaped; ovipositor, ventral and dorsal laminae unilobed, laminal rod present; distal margin of pygidium not incised, distal margin of male sixth sternite slightly incised. Alimentary canal (Figure 18(m)): no external evidence of ventricular crypts, four cryptonephridial malpighian tubules, stomodaeal valve comprised of four primary lobes, dorsal and ventral lobes reduced in size. Male mesodermal internal reproductive organs (Figure 18(k)): one pair of accessory gland. Female mesodermal internal reproductive organs (Figure 18(1)): spermathecal capsule ovoid, well sclerotized, spermathecal gland attached to apex of spermathecal capsule.

Distribution. Tarsostenus univittatus (Rossi) and T. carus (Newman) are cosmopolitan. Other species are known from Australia and New Caledonia.

Species Examined. Tarsostenus carus (Newman), T. univittatus (Rossi), and one undescribed species.

Notes. Kolibáč [43] presented a variety of illustrations about the organs of T. univittatus (Rossi).

4.5.19. Thriocera Gorham (Figures 19(a)-19(f), 20(e), 19(f), 21(c), and 23(h)). Thriocera Gorham [44]. Type species: Corynetes pectoralis Klug [45]. By original designation. Corporaal [5].

Synapotypic Characteristics. A uniquely derived characteristic has not been found.

Diagnosis. This is the only genus of Tarsosteninae which is oblong-short, lacks asetiferous punctations on the elytral disc, and has a 0-2-2 tibial spur formula.
Description. Size: length $3.6-7.0 \mathrm{~mm}$; width $1.2-2.5 \mathrm{~mm}$. Form (Figure 23(h)): oblong short rectangulate to narrow rectangulate, about 3 times longer than broad. Vestiture: disc of cranium and pronotum vested profusely with erect setae, elytral disc vested profusely with tall erect setae and shorter decumbent setae. Head (Figures 19(a), and 19(b)): cranium quadrate, frons much wider than width of eye, indented with very small setiferous punctations; gula (Figure 19(a)), large, trapezoidal, sutures oblique, gular processes widely separated, processes in form of two setiferous tubercles; labrum short, deeply incised, transverse tormal processes confluent, epipharyngeal plate very small; mandible, body short, anterior and medial dens well developed, posterior dens not well developed, penicillus well developed; maxilla (Figure 20(f)), laterolacinia absent, terminal palpomere subsecuriform; labium, ligula not incised, terminal palpomere subsecuriform; eyes small, finely faceted, ocular notch large; antenna (Figure 21(c)), capitate, capitulum compact, scape about as long as combined length of pedicel and antennomere 3, funicular antennomeres filiform, capitular antennomeres expanded, antennomeres 9 and 10 expanded, antennomere 11 ovoid. Thorax: pronotum (Figures 19(c) and 19(d)), quadrate, disc indented profusely with small setiferous punctations, lateral margins variously convex, dorsolateral ridge extends from posterior angle to anterior angle, not fractured and with smooth surface, sclerotized region above pronotal projection glabrous, prebasal fissure shallow, prointercoxal process expanded distally; pronotal projections short; elytron sculptured with numerous setiferous punctations, punctations not seriate, basal uncus variously developed, with or without elongate setae, epipleural fold laterally positioned, narrowed abruptly narrowed at elytral posterior two-thirds, anterior margin carinate; metathoracic wing with wedge cell open; metendosternite with furcal lamina, furcal anterior plate not prominent; legs, tibial spur formula $0-2-2$, tarsal pulvillar formula 3-3-3, unguis with denticle. Abdomen: aedeagus (Figure 19(f)), shorter than length of abdomen, phallobase not reduced, not lobate, not fimbriate; phallic lateral plates narrow, phallobasic rod linear, phallic apex globose, spicular plates triangular and acuminate, spicular apodemes fused in posterior third (Figure 19(e)), intraspicular plate rod shaped; ovipositor, ventral and dorsal laminae unilobed, laminal rod present; distal margin of pygidium not incised, distal margin of male sixth sternite slightly incised. Alimentary canal: not studied. Male mesodermal internal reproductive organs: not studied. Female mesodermal internal reproductive organs: not studied.

\section{Distribution. Known only from Africa.}

Species Examined. Thriocera pectoralis (Klug) and 12 other species which may or not be described.

4.5.20. Thriocerodes Wolcott \& Dybas (Figures 19(g)-19(j), 21(a), 21(b), and 23(i)). Thriocerodes Wolcott \& Dybas [46]. Type species: Incorynetes bifasciatus Pic [47]. Designation by Kolibáč [6]. Corporaal [5]. 
Synapotypic Characteristics. Phallic apex digitiform, CuA vein oblique.

Diagnosis. Blackburniella Chapin, Fallopylus gen. nov., Tarsostenodes Blackburn, Tarsostenus Spinola, and Thriocerodes Wolcott \& Dybas are characterized by having a 1-2-1 tibial spur formula. Specimens of Thriocerodes may be distinguished from specimens of the other aforementioned genera by having a transverse pronotum.

Description. Size: length $3.0-6.0 \mathrm{~mm}$; width $1.0-2.0 \mathrm{~mm}$. Form (Figure 23(i)): oblong short rectangulate, about 3 times longer than broad. Vestiture: disc of cranium and pronotum vested profusely with pale setae, elytral disc with serially arranged asetose punctations and with $1^{\circ}$ setae and shorter serially arranged $2^{\circ}$ setae. Head (Figures $19(\mathrm{~g})$, 19(h), and 21(a)): cranium quadrate, frons much wider than width of eye, indented with very small setiferous punctations; gula (Figure 19(g)), large, trapezoidal, sutures oblique, gular processes widely separated, processes in form of two setiferous tubercles; labrum short, not deeply incised, transverse tormal processes confluent, epipharyngeal plate very small; mandible, body short, anterior and medial dens well developed, posterior dens not well developed, penicillus well developed; maxilla (Figure 21(b)), laterolacinia present, terminal palpomere subsecuriform; labium, ligula incised, terminal palpomere subsecuriform; eyes large, coarsely faceted, ocular notch large; antenna, capitate, capitulum lax, scape about as long as combined length of pedicel and antennomere 3, funicular antennomeres subfiliform, capitular antennomeres slightly expanded, antennomeres 9 and 10 expanded, antennomere 11 subquadrate. Thorax: pronotum (Figures 19(i) and 19(j)), subquadrate, lateral margins with median tubercle, dorsolateral ridge extends from posterior angle to anterior angle, sclerotized region above pronotal projection glabrous, prebasal fissure shallow, prointercoxal process not expanded distally; pronotal projections short; elytron sculptured with serially arranged asetiferous punctations, epipleural fold laterally positioned, narrowed to elytral apex, anterior margin carinate; metathoracic wing with wedge cell open, $\mathrm{CuA}$ vein oblique; metendosternite with furcal lamina, furcal anterior plate prominent; legs, tibial spur formula 1-2-1, tarsal pulvillar formula 3-3-3, unguis without denticle. Abdomen: aedeagus shorter than length of abdomen, phallobase not reduced, lobate, not fimbriate; phallic lateral plates narrow, phallobasic rod linear, phallic apex digitiform, spicular plates triangular, not acuminate, spicular apodemes fused or not, intraspicular plate rod shaped; ovipositor, ventral and dorsal laminae unilobed, laminal rod present; distal margin of pygidium not incised, distal margin of male sixth sternite slightly incised. Alimentary canal: not studied. Male mesodermal internal reproductive organs: not studied. Female mesodermal internal reproductive organs: spermathecal capsule well sclerotized, spermatheca gland attached to subapex of spermathecal gland, saccular bursa copulatrix well developed.

Distribution. This genus is known from Australia.
Species Examined. Thriocerodes bifasciatus (Pic), T. bipartitus (Pic), T. corporaali Wolcott \& Dybas, T. pygmaeus (Blackburn), T. pyloides Kolibáč, T. rolciki Kolibáč, and four undescribed species.

Notes. Kolibáč [6] provides illustrations of species of Thriocerodes.

\section{Acknowledgments}

Jaime Solervicens A. generously allowed the author to use habitus Figures 3(a) and 9, and Justin Bartlett kindly reviewed the paper.

\section{References}

[1] W. Opitz, "Classification, natural history, phylogeny, and subfamily composition of the Cleridae and generic content of the subfamilies (Coleoptera: Cleroidea)," Entomologica Basiliensia et Collectionis Frey, vol. 32, pp. 31-128, 2010.

[2] W. Opitz, "Classification, natural history, and evolution of the Epiphloeinae (Coleoptera: Cleridae). Part I. The genera of Epiphloeinae," Insecta Mundi, vol. 11, no. 1, pp. 51-96, 1997.

[3] W. Opitz, "Classification, natural history, and evolution of Neorthopleurinae subfam.nov. (Coleoptera, Cleridae). Part I. Generic composition of the subfamily and key to genera," Entomologica Basiliensia et Collectionis Frey, vol. 31, pp. 135207, 2009.

[4] W. Opitz, "Classification, natural history, and evolution of Korynetinae Laporte (Coleoptera: Cleridae). Part I. Generic composition of the subfamily and key to genera," Journal of Afrotropical Zoology, vol. 7, pp. 29-67, 2011.

[5] J. B. Corporaal, "Cleridae," in Coleopterorum Catalogus. Supplementa. Pars 23 (Editio secunda), W. D. Hincks, Ed., Dr. W. Junk, 'S-Gravenhage, The Netherlands, 1950.

[6] J. Kolibáč, "A review of Australian genera of Korynetinae (Coleoptera, Cleridae)," Entomologica Basiliensia, vol. 25, pp. 41-97, 2003.

[7] W. Hennig, Phylogenetic Systematics, University Press, Urbana, Ill, USA, 1966.

[8] P. A. Goloboff, "NONA version 2.0. A tree searching program," Distributed by the author, 2003.

[9] K. C. Nixon, "Winclada ver. 1.00.08," Published by the author, 2002.

[10] G. Ekis, "Classification, Phylogeny, and Zoogeography of the Genus Perilypus (Coleoptera: Cleridae)," Smithsonian Contributions to Zoology, vol. 227, pp. 1-138, 1977.

[11] K. C. Nixon and J. M. Carpenter, "On Outgroups," Cladistics, vol. 9, no. 4, pp. 413-426, 1993.

[12] M. Spinola, Essai Monographique sur les Clérites. Tome Premier, Gênes, Imprimerie des Frères Ponthenier, 1844.

[13] A. L. Peracchi, "Dois novos generous e uma nova espécie de Enopliinae do Brasil (Coleoptera, Cleridae)," Anais do II Congresso Latino-Americano de Zoologia, vol. 1, pp. 115-123, 1964.

[14] A. M. Lea, "The Coleoptera of King Island, Bass Strait," Proceedings of the Royal Society of Victoria, vol. 20, no. 2, pp. 143-207, 1908.

[15] J. S. Bartlett, "Taxonomic revision of Apteropilo Lea, 1908 (Coleoptera: Cleridae)," Zootaxa, no. 2200, pp. 41-53, 2009.

[16] E. A. Chapin, "Blackburniella, nov. nom. For Thanasimomorpha, Blackb. (Coleoptera: Cleridae)," Transactions of the Royal Society of South Australia, vol. 48, pp. 65-66, 1924. 
[17] T. Blackburn, "Further notes on Australian Coleoptera, with description of new genera and new species. Cleridae," Transactions of the Royal Society of South Australia, vol. 14, no. 2, pp. 302-306, 1891.

[18] E. G. Matthews, "Family Cleridae," in A Guide to the Genera of Beetles of South Australia, E. G. Matthews, Ed., pp. 4-5, South Australian Museum, Adelaide, Australia, 1992.

[19] A. B. Wolcott, "Description of a new genus and four new species of American Cleridae," Coleopterological Contributions, vol. 1, no. 1, pp. 105-110, 1927.

[20] J. Solervicens, "Curacavi, nuevo genero de Cleridae de Chile Central (Coleoptera: Clerinae: Enopliinae)," Acta Entomológica Chilena, vol. 24, pp. 61-64, 2000.

[21] S. Schenkling, "Neue Beiträge zur Kenntnis der Cleriden (Col.),VI. 34," Entomologische Mitteilungen, vol. 6, pp. 282 283, 1917.

[22] W. J. Macleay, "Notes on a collection of insects from Gayndah. Cleridae," Transactions of the Entomological Society of New South Wales, vol. 2, pp. 268-275, 1872.

[23] M. A. Chevrolat, Mémoire sur la Famille des Clérites, Buquet, Paris, France, 1876.

[24] J. Schenkling, "Neopylus nahuelbutensis, nuevo genero y especie de Enopliinae de Chile (Coleoptera, Cleridae)," Acta Entomológica Chilena, vol. 15, pp. 233-236, 1989.

[25] E. Newman, "List of insects collected at Port Philip, South Australia, by Edmund Thomas Higgins, Esq," The Entomologist, vol. 1, pp. 361-369, 1842.

[26] A. H. Elston, "Australian Coleoptera. Part VI," Transactions and Proceedings of the Royal Society of South Australia, vol. 53, pp. 247-352, 1929.

[27] E. Newman, "Entomological notes," The Entomologist, vol. 1, pp. 33-37, 1841.

[28] M. Spinola, "Monographie des Térédiles," Revue Zoologique, par La Société Cuvierienne, vol. 4, pp. 70-76, 1841.

[29] L. Fairmaire, "Coléoptères recueillis par M. Raffray, à Madagascar et descritions des spèces nouvelles," Annales de la Société Entomologique de France, vol. 6, pp. 31-96, 1886.

[30] L. Fairmaire, "Materiaux pourla faune Coleopterique de la region Malgache," Annales de la Societe Entomologiques de France, vol. 71, pp. 530-568, 1902.

[31] A. F. Kuwert, "Die Cleridengattungen Madagascars," Annales de la Société Entomologique de Belgique, vol. 38, pp. 1-5, 1894.

[32] L. Fairmaire, "Coléoptères du Kilimandjaro et des environs," Annales de la Société Entomologique de Belgique, vol. 38, pp. 386-395, 1894.

[33] S. Schenkling, "Coleoptera, Malacodermata, fam. Cleridae," in Genera Insectorum, vol. 13, pp. 1-124, P. Wytsman, Bruxelles, Ireland, 1903.

[34] M. Pic, "Nouveautés diverses," Mélanges Exotico-Entomologiques, vol. 65, pp. 1-36, 1935.

[35] J. Solervicens, "Cambios taxonómicos y nuevos registros de Clérodos (Insecta: Coleoptera)," Acta Entomológica Chilena, vol. 29, pp. 45-46, 2005.

[36] T. Blackburn, "Cleridae," Transactions of the Royal Society of South Australia, vol. 24, pp. 116-140, 1900.

[37] J. S. Bartlett, "The cleridae of lord howe Island, with descriptions of two new species (coleoptera: Cleroidea)," Records of the Australian Museum, vol. 61, no. 2-3, pp. 225-228, 2009.

[38] K. M. Heller, "Die Kafer von Neu-Caledonien und den Benachbarten Inselgruppen," in Nova Caledonia: Recherches scientifiques en Nouvelle-Caledonie et aux Iles Loyalty, F. Sarasin and J. Roux, Eds., vol. 2 of Fam. Cleridae, pp. 277-278, C. W. Kreidels, Weisbaden, Germany, 1916.
[39] P. Rossi, Mantissa Insectorum, exhibens species nuper in Etruria colectas, adjectis faunae Etruscae illustrationibus ac emendationibus. Volume 1, (description of Clerus univittatus), 1792.

[40] R. A. Crowson, "A review of the classification of Cleroidea (Coleoptera),with description of two new genera of Peltidae and of several new larval types," Transactions of the Royal Entomological Society of London, vol. 116, no. 12, pp. 275-327, 1964.

[41] G. Ekis and A. P. Gupta, "Digestive system of Cleridae (Coleoptera)," International Journal of Insect Morphology and Embryology, vol. 1, no. 1, pp. 51-86, 1971.

[42] W. Opitz, "Family 73. Cleridae," in American Beetles, R. H. Arnett, M. C. Thomas, P. E. Skelley, and J. H. Frank, Eds., vol. 2, pp. 267-280, CRC Press, Boca Raton, Fla, USA, 2002.

[43] J. Kolibáč, "Further observation on the morphology of some Cleridae (Coleoptera). I," Acta Scientiarum Naturalium Academiae Scientiarum Bohemoslovacae Brno, vol. 23, no. 1, pp. 1-50, 1989.

[44] H. S. Gorham, "Descriptions of new genera and species of Cleridae, with notes on the genera and corrections of synonymy," Transactions of the Royal Entomological Society of London, vol. 1878, no. 4, pp. 153-167, 1878.

[45] J. C. F. Klug, "Versuch einer systematischen Bestimmung und Auseinandersetzung der Gattungen und Arten der Clerii, einer Insectenfamilie aus der OrdNung der Coleopteren," Abhandlungen Berlin Akademie der Berlin Wissenschaften, vol. 1842, pp. 259-397, 1842.

[46] A. B. Wolcott and H. S. Dybas, "Two new beetles from Costa Rica and Australia with description of a new genus (Coleoptera, Cleridae)," Fieldiana-Zoology, vol. 31, no. 18, pp. 143-148, 1947.

[47] M. Pic, "Diagnoses de Coléoptères exotiques (Suite)," L'Echange, vol. 57, no. 483, pp. 2-4, 1941. 

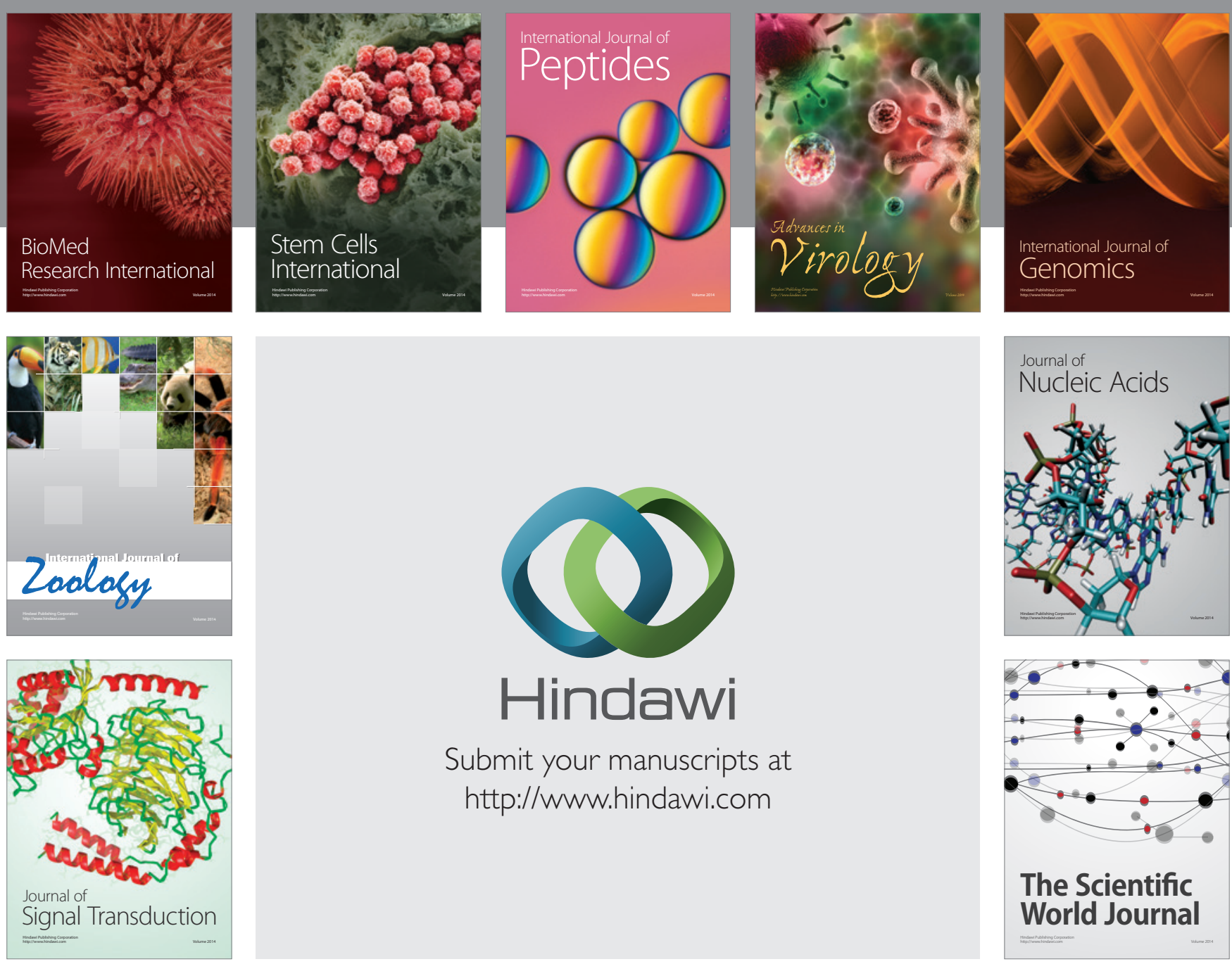

Submit your manuscripts at

http://www.hindawi.com
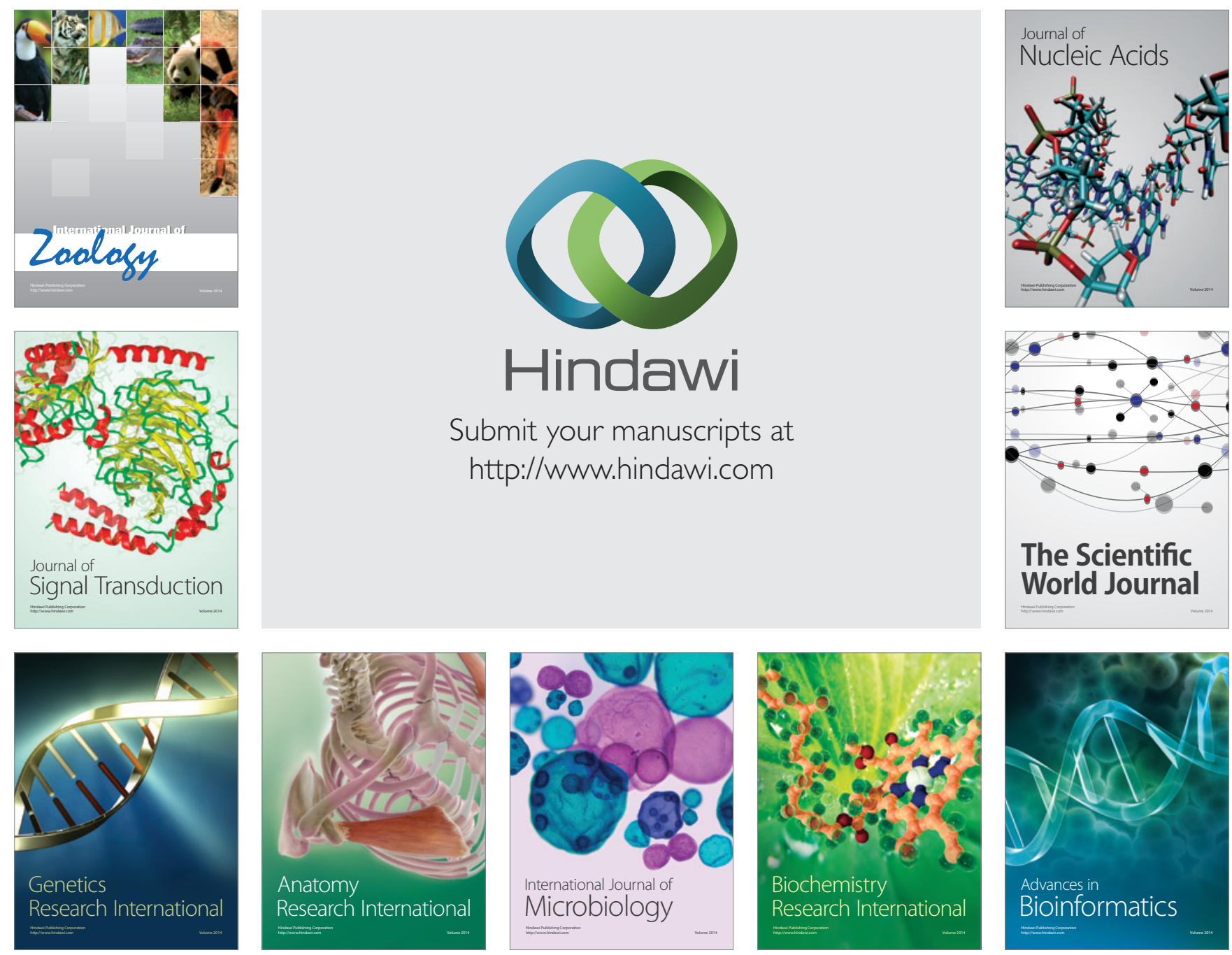

The Scientific World Journal
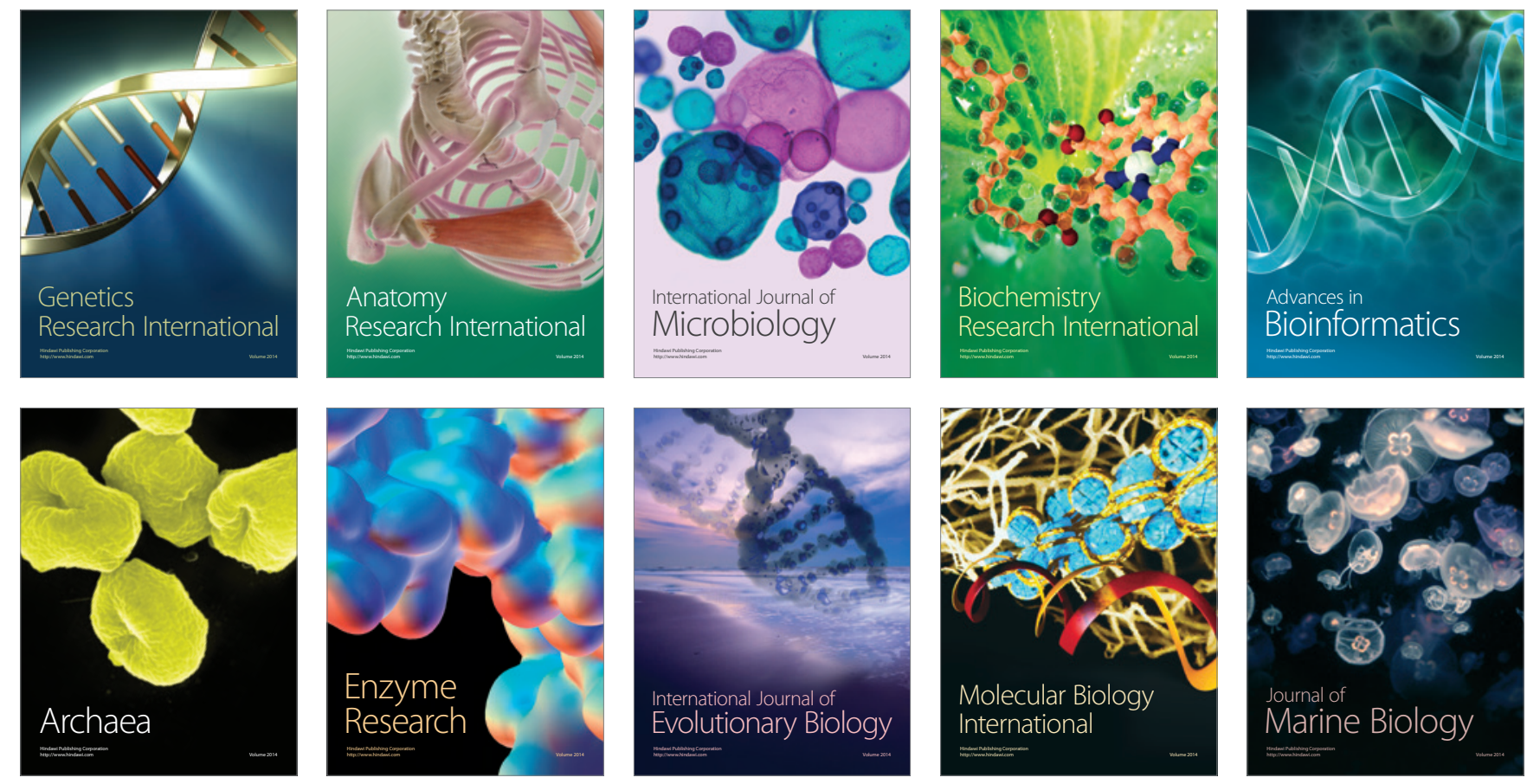